\title{
Complex networks to understand the past: the case of roads in Bourbon Spain
}

\author{
Federico Pablo-Martí ${ }^{1,2}$ (i) $\cdot$ Ángel Alañón-Pardo ${ }^{3}$. Angel Sánchez ${ }^{4,5,6}$
}

Received: 19 October 2019 / Accepted: 5 September 2020 / Published online: 6 October 2020

(c) Springer-Verlag GmbH Germany, part of Springer Nature 2020

\begin{abstract}
The work aims to study, using GIS techniques and network analysis, the development of the road network in Spain during the period between the War of Succession and the introduction of the railway (1700-1850). Our research is based on a detailed cartographic review of maps made during the War of Succession, largely improving preexisting studies based on books of itineraries from the sixteenth century onwards. We build a new, complete map of the main roads at the beginning of the eighteenth century along with the matrix of transport costs for all the important towns describing the communications network. Our study of this complex network, supplemented by a counterfactual analysis carried out using a simulation model based on agents using different centralized decision-making processes, allows us to establish three main results. First, existing trade flows at the beginning of the eighteenth century had a radial structure, so the Bourbon infrastructure plan only consolidated a preexisting situation. Second, the development of the network did not suppose important alterations in the comparative centrality of the regions. Finally, the design of the paved road network was adequate for the economic needs of the country. These findings are in stark contrast with claims that the radial structure of the Bourbon roads was designed ex-novo with political or ideological objectives rather than economic ones. Our methodology paves the way to further studies of path-dependent, long-term processes of network design as the key to understanding the true origin of many currently existing situations.
\end{abstract}

Keywords Road network · Spain · GIS · Agent based simulation

JEL Classification $\mathrm{C} 63 \cdot \mathrm{C} 8 \cdot \mathrm{N} 73 \cdot \mathrm{R} 42$

Federico Pablo-Martí

federico.pablo@uah.es

Extended author information available on the last page of the article 


\section{Introduction}

\subsection{General context and applications}

Few historical processes are so relevant to understand our present as the design and temporal development of transport networks. As these are processes with a strong path dependence (David 1985), decisions that were made long ago continue to directly and intensely affect society in areas as diverse as economic growth (Peters 2003; Calderón and Servén 2004; Faber 2014), territorial cohesion (Badenoch 2010; Crescenzi and Rodríguez-Pose 2012; Monzon et al. 2019; Naranjo Gómez 2016), urban development (Weber 2012; Modarres and Dierwechter 2015) or electoral processes (Nall 2015, 2018). Consequently, knowledge of the motivations behind the implementation of the new transport infrastructures, of the economic and territorial effects they induced and of the adequacy of their design are therefore important focuses of attention not only for academic analysis but also for social and political debate. In this area, the development of national road networks is one of the issues of greatest interest since they form the basis on which the other transport networks are implemented. The works about the European motorway network (Peters 2003; Badenoch 2010; Crescenzi and RodríguezPose 2012), the Chinese (Faber 2014) or the American one (Nall 2015; Modarres and Dierwechter 2015) are clear examples of this interest.

Improvements in transport infrastructure have been considered by centuries (Ward 1762; Smith 1776) as essentially positive, as they lead to economic growth and poverty alleviation through reductions in transport costs and the facilitation of market integration (Calderón and Servén 2004). However, accessibility problems can sometimes benefit certain economically weaker territories by protecting their producers from competition from other regions with lower costs and greater product variety (Peters 2003). If the development of new transport networks is to improve territorial balance, there must be sectors capable of withstanding increased competition; otherwise, market integration can lead to self-sustaining inequality (Martin 1999; Asher and Paul 2016). On the other hand, the long time required for the development of road networks can generate permanent differential effects on the development of regions even if the final design is territorially neutral. During the period of network construction, traffic flows are altered, possibly inducing variations in the comparative advantage of cities that can become permanent and subsist after completion (Berger and Enflo 2017) or even after their disappearance (Bleakley and Lin 2012; Aggarwal 2018).

The case we concern ourselves within this paper, namely the design and first development of the contemporary Spanish road network, falls within this area of research, although it is older than the cases mentioned above. Interestingly, more than two centuries after Charles III formally established the guidelines that determined its design and its present structure, it continues to be the object of lively social attention, as evidenced by the large number of recent historical (Rosés et al. 2010; Martínez-Galarraga 2010; Bel 2011; Martinez-Galarraga 2012; Fernández-de Pinedo Echevarría and Fernández-de Pinedo Fernández 2013; 
Díez-Minguela et al. 2016) and non-historical academic works (Bel 2010; Molinas 2013; Holl 2011, 2012; Garcia-López 2012; Martínez-Galarraga et al. 2015; Garcia-López et al. 2015; Holl 2016), as well as by the abundant news or political discussions ${ }^{1}$ that take place around it. However, the scope of this paper goes way beyond the specific historic process we study: We are introducing a methodology combining deep and thorough historical research, computer geolocalization techniques, analytical tools of complex network science and agent-based modeling, that can be applied to many other processes. It is becoming increasingly clear that sizable gains can be realized from research that seeks to better understand how local history and context can be leveraged to inform the design of better policy (Nunn 2020). As we will see below, our methodology can be very useful in that context, providing deep insights such as assessing whether a process is pathdependent or not, identifying the effects and disequilibria of processes at multiple levels (national, regional, town), studying counterfactuals to advise policy making, and in sum, providing a faithful picture of the system of interest useful for understanding the past and handling the future.

\subsection{Research questions and hypotheses to study}

The origin of the current radial structure of the Spanish road network and, in general, of its transport network, has been the object of extensive historical debate (Tortella 1973; Nadal 1975; Artola et al. 1978; Mateo del Peral 1978; Gómez Mendoza 1982; Comín Comín et al. 1998; Bel 2011) due to its influence on Spain's subsequent economic development and its territorial imbalances, but most of the available research addresses the period after 1850 . In turn, the possibility that the decisions are taken in the eighteenth and the nineteenth centuries regarding the design of the transport networks have generated a lock-in (Arthur 1989) that has prevented the subsequent development of more efficient transport networks at present is an issue of great relevance but has not been the subject of many quantitative studies. As far as we know, the studies that have analyzed it from a quantitative perspective have been very limited and focused on the railways (Equipo Urbano 1972; Martí-Romero et al. 2020). The works of Carreras Montfort and de Soto are an important exception, but they mainly refer to the Roman period (Carreras Montfort and de Soto 2013; de Soto 2019). Their analysis for the roads of the eighteenth century uses the work of Escribano (1758) as a main geographical reference, which implies a significant restriction in terms of time reference and potential geographical bias as they acknowledge (Carreras Monfort and de Soto 2010, p. 13).

\footnotetext{
1 An indirect evidence of the social interest about this topic can be found by comparing the number of results obtained in Google with other similar ones. So, while the searches "carreteras and "Felipe V", and "carreteras and "Carlos III"' obtained 174,000 and 1.160,000 results respectively, the searches "ferrocarriles and "Isabel II"" and "ferrocarriles and "Alfonso XII"" were only 363.000 and 176.000, although these are more recent facts. The interest for non-Spanish speakers is also high: "roads and "Charles iii" Spain' had 179.000 results while 'roads "Albert Gallatin"” yields 183.000 hits and "Interstate Highway System"' 1.050 .000 ones (searched on January 9, 2020).
} 
The works that have provided a more direct and quantitative approach to the eighteenth-century road network make a somewhat negative assessment of it (Madrazo Madrazo 1984b; Uriol Salcedo 2001; Martinez-Galarraga 2012). However, these works concern themselves more with an assessment of its results than with a detailed analysis of its layout comparing it with other alternative designs of the network. In fact, other authors accepted that there were some improvements from the previous situation (Herranz-Loncán 2005; Grafe 2012). In this context, it has to be borne in mind that path dependence and consequent lock-in are phenomena that occur under particular conditions and are the result of underlying, more fundamental mechanisms (Vromen 1995). Therefore, it is necessary to adopt an approach of 'path as process,' in which the development of road networks must be understood as a continuous process of generation and destruction of optimal trajectories for the agents which produce a transformation of the existing socioeconomic structures and regional development trajectories (Garud and Karnøe 2001; Martin and Sunley 2006). This aligns with what Bednar et al. (2012) calls 'revised-path dependence,' which is of crucial importance in the interpretation of political and legal issues but also economic decisions. This implies as well that policy choices as the construction of new roads must be evaluated in light of decisions taken during the process, not just the final equilibrium.

For our work on the origin and evolution of the radial structure of the Spanish road network, these ideas lead us to ask whether the design of the network was unavoidable given the topological characteristics of the territory or whether it resulted from small events as the political decisions. From our point of view, an event generates path dependence when it alters the preexisting dynamics in the system, by exceeding its capacity of resilience. This resilience is usually high, and non-chaotic dynamic systems show a tendency to maintain and recover their dynamics, but if the actions or influences on it exceed certain thresholds they can change their evolution in a lasting way in time.

In this framework, the road network can be seen as a system in which the links are continuously weakened and require maintenance to remain functional. Improvements to the sections require specific investments to take place. The flows between the nodes derive from their relative position and size, but this is, in turn, affected by the network. There is, therefore, a dynamic of the development of the nodes that can be altered depending on decisions such as the order of execution of the works. This is a complex phenomenon and is multi-scale both in terms of time and space. From a historical viewpoint, the process is affected by the vision of permanence of the human being, and events that last more than one generation are usually considered to be permanent even though they are not permanent. From the spatial point of view, events that do not produce permanent changes in the system when considered as a whole can produce very relevant alterations at the local level. All this makes the consideration of an event as a path-dependent one always complicated and requires a precise definition of the reference framework and the spatial domain under consideration.

From the perspective summarized above, in this paper, we use historical data, GIS techniques, and network analysis, to critically examine three statements widely discussed in the literature but far from empirically validated. 
The first statement is that the dynastic change after the War of Succession meant the ex novo implementation of a radial design of the road network that replaced a preexisting, less centralized one. The works about the issue consider that the radial structure of the Spanish communications network arises around 1720 through the General Regulations for the Direction and Government of the Post and Post Offices of Spain (Uriol Salcedo 1977; Madrazo Madrazo 1984a, b; Ruiz et al. 2015) or, alternatively, and focusing on the roads, with the Royal Decree issued in 1761 to make straight and solid roads in Spain and to facilitate trade between provinces (de Gregorio - Marqués de Esquilache 1761). This radial structure is usually linked to a more centralized vision of Spain motivated by the Enlightened vision of the new dynasty (Uriol Salcedo 1985a, b; Shaw 2009; Carreras Monfort and de Soto 2010; Bel 2011; Garcia-López et al. 2015; López Ortiz and Melgarejo Moreno 2016). To analyze this statement more precisely, we have divided it into two hypotheses: H1A: 'The newly paved roads of the pre-rail period imply the introduction of a new network design.' H1.B: 'The changes in the road network are linked to the Enlightenment vision of the State that came with the Bourbon dynasty.'

The second statement posits that the new roads generated significant changes in the transport network that led to improving the communications of Madrid with the periphery instead of activating the growth of the interior regions (Ringrose 1972; Anes 1974; Carr 1978; Madrazo Madrazo 1984b). To verify this statement, quite consolidated in the literature though not entirely (Grafe 2012), we will use three hypotheses: H2.A 'The newly paved roads produced important changes on the interregional mobility patterns'; H2.B 'The improvements in accessibility resulting from the newly paved roads were concentrated in a few regions, mainly Madrid and the coastal regions, which was a comparative disadvantage for the inland regions,' or, in other words, 'those investments affected the regions differently'; H2.C 'The effects were mainly at the level of cities, not so much of regions.'

Finally, the third statement we address is whether the network design is compatible with diverse economic efficiency criteria. More precisely, we consider two hypotheses: First, H3.A 'the radial network designed by the Bourbon monarchs of the second half of the eighteenth century emerges from a distributed decisionmaking process in which all the populations of the nation are taken into account in a non-discriminatory manner' (Martinez-Galarraga 2012). Second, H3.B, 'the military, political or administrative criteria outlined by various authors (Ringrose, Gómez Mendoza, Madrazo, Bel) are compatible with that of maximizing commercial traffic' (Ringrose 1972; Anes 1974; Madrazo Madrazo 1984a, b; Gómez Mendoza 2001; Bel 2011).

Our research is based on three pillars. First, we carry out an in-depth historic analysis of the time evolution of the land communications in Spain, from the midsixteenth century through the eighteenth century. Our work presents the most detailed and well-documented study of this process to date, based on an exhaustive search of relevant maps and reports about the structure of the road network. Second, we resort to complex network analysis techniques, that are becoming widely used in many disciplines, to quantify the effect of the historical evolution of the road network on the communication structure of the territory. Finally, we introduce an agentbased model that allows us to explore different counterfactuals to obtain a network 
that would result from different decision-making processes. We compare centralized processes with other coordinated, democratic alternatives that considered the distribution of the population in the territory, assessing the relevance of politically motivated decisions on the evolution of the network.

\section{The Bourbon road network and its historical framework}

\subsection{Spanish roads at the beginning of the eighteenth century}

In this section, we present an in-depth study of the historic evolution of the Spanish land transportation network. We aim to show that the road network in Spain that emerged after the War of Succession was the same from the beginning of the Modern Age, since during the sixteenth and seventeenth centuries investments in transport infrastructure were reduced and in most cases limited to road maintenance tasks.

Although it is pointed out often that the modern road network in Spain has its roots in Roman roads (Uriol Salcedo 1985a; Bel 2011; Garcia-López et al. 2015), this statement is only partially true. To the extent that the orographic conditions, that is, the physical characteristics of the territory such as river and mountains, remained largely unchanged, as advances in construction technologies were not yet too important, ${ }^{2}$ and many of the large population centers of the Roman era were still relevant at the beginning of the 18th century, both networks show important similarities from their functionality as they give answers to similar problems and, therefore, many of their links connect the same nodes. However, from a technical perspective, they are different, as the roads run along largely mismatched routes. In most cases, eighteenth-century roads only overlap with old carriageways at the entrances to cities, on bridges, and on mountain passes that were still preserved from Roman times (cf. "Appendix," Fig. 21). In any event, it is commonly accepted that the network of roads existing at the beginning of the eighteenth century was not structured around particularly important roads or cities, showing high road densities in Old Castile and low densities in the northwest of the peninsula (Galicia and Asturias) and the southwest part of the central plateau. It was also a markedly internal network, in which connectivity with coastal towns was practically non-existent, except with Catalonia and the north of Valencia. In terms of quality, it was quite inadequate, even by the standards of the time (Dirección General de Obras Públicas 1856), making the widespread use of carts in the transport of goods difficult (Menéndez Pidal 1951; Madrazo Madrazo 1984a, b; Uriol Salcedo 2001). In what follows, we critically consider this view and appraise its accuracy and the data on which it is based.

One first point we need to consider is that the spatial relations between townsthe topology — of the underlying road network is a crucial aspect in assessing the suitability of infrastructure investment decisions. However, most studies on changes

\footnotetext{
2 The first tunnel made by explosives was that of Malpas (Juncà Ubierna 1997) in 1679 and the first railway tunnel in Spain was that of Montgat in 1848.
} 
in the transport network linked to the arrival of the Bourbons do not rely on cartographic information, but on books of itineraries and accounts of travelers (Madrazo Madrazo 1984a; Uriol Salcedo 2001; Bel 2010; Carreras Monfort and de Soto 2010) dating in most cases to two centuries before (Villuga 1546; de Meneses 1576) or already halfway through the century (Escribano 1758). Crucially, maps and itineraries have different purposes, being related to either 'state' or 'process' as explained by (Downs and Stea 1977). In the eighteenth century, maps offered much richer and more general information, but were expensive and could sometimes lead to confusion if they were misrepresented. Itineraries, on the other hand, were simply lists of the towns located on the roads, i.e., they had much more limited but clearer information. Among their main shortcomings was that itineraries cannot be connected, no matter how close they are, if they do not have towns in common; this could make travelers incur big detours. However, their reliability and low reproduction costs meant that they were widely used until the end of the nineteenth century.

Only in the field of postal communications have maps received some attention (Líter Mayayo 2005; Aranaz del Río 2005), although generally from a purely descriptive perspective. It is widely accepted that these itineraries did not reflect the entire network, but only a selection of roads that were relevant to the small public to which they were addressed, given the large proportion of the illiterate population. Madrazo Madrazo (1984a), for example, considers that the actual network may have been twice the size of the reported one. Further comparison with the information provided in the Topographic Relations of Felipe II (Páez de Castro et al. 1578) for Toledo and Madrid shows that a multitude of roads is missing (Alvar Ezquerra 1985; Madrazo Madrazo 1984a). Uriol Salcedo (2001) gives further support to the idea that there is a lack of important roads according to other sources, such as chronicles of travelers.

In this situation, itineraries remain the most suitable sources for the analysis of the structure of the road network in the sixteenth and seventeenth centuries, as they were generally more accurate than maps. This is not the case, however, for the eighteenth century, ${ }^{3}$ in which there were already detailed road maps such as those of de Wit (1700), Fer et al. (1701), Valk (1704), Visscher (1704, 1705), van der Aa (1707), Senex (1708), Mortier and Sanson (1708), Allard (1710), Homann and Remshard (1710), Mortier (1710), and Moll et al. (1711). Many of these maps, of French, English, and, above all, Flemish origin, were compiled for military reasons during the War of Succession (1701-1714) and precede by four decades the unfinished work of the Jesuits Carlos Martínez and Claudio de la Vega, commissioned by the Marqués de la Ensenada (Martínez et al. 1743), the first national attempt to have a detailed map of the roads of Spain. This surprising lack of attention by historians to the cartography of the early eighteenth century is likely to arise from three interrelated motives. On the one hand, it was difficult to access these materials before their digitization and dissemination on the Internet. On the other hand, primary sources such as Sarmiento (1757) discredited them with claims that in the middle

\footnotetext{
3 At the regional level, there are already road maps in the second half of the seventeenth century (Duval 1659; Sanson 1652, 1691; Borsano 1687).
} 

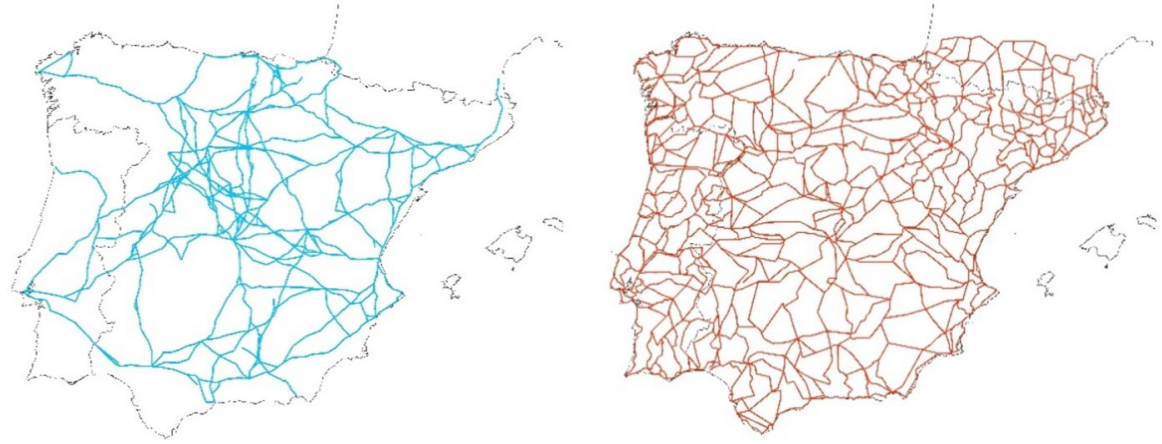

Fig. 1 Road network in Spain at the beginning of the eighteenth century. Left: map based on Villuga (1546) showing a network with a highly heterogeneous density, i.e., with zones with very many roads and other zones in which they barely exist. Notice the important lack of communication with the coast, implying a degree of disconnection between the periphery and the peninsular center. Right: map based on Valk (1704), showing a quite homogeneous road density across the Iberian peninsula, good communications with the coast, and without noticeable discontinuities across reigns. Maps by the authors from the references indicated above

of the century there were still no general maps of Spain with the cartographic precision necessary to adequately determine the itineraries by 'air.' This amounts to saying that serious errors made it very difficult to define the general scheme of the road network, because the distances that appeared between the cities were not correct. Finally, there was also an inadequate interpretation of secondary sources such as Madrazo Madrazo (1984a) that confuse the lack of precise general maps with the lack of reliable maps and, in any case, of more detailed and complete maps than the itineraries. Despite these issues, road maps of the early eighteenth century, although still imprecise in terms of distances because the location of the cities and towns still showed some degree of error, gather complete information on the road connectivity between them. Hence, by applying these connections to current maps in which the locations of the towns and cities is exact, it is possible to reconstruct accurately the old road maps.

Figure 1 shows the differences between the two visions, i.e., the itinerary vs the map approaches, comparing the network that appears in the itinerary of Villuga (1546) with that of the map of Valk (1704). The latter clearly shows that, as in the rest of the maps of the period, the density of the network is quite high and homogeneous in all the territory and that the coastal zones have adequate connectivity with the interior, which contrasts not only with the itineraries of the sixteenth century but also with those of Escribano of 1758.

Importantly, none of the maps analyzed in this work shows a categorization of roads, which suggests that there were no significant differences in quality between the roads included. In general, all of them were quite deficient and scarcely financed, as shown by the Report on the state of Public Works in Spain (Dirección General de Obras Públicas 1856, p. 16, translation by the authors): 
The roads that existed in Spain before the middle of the eighteenth century were nothing more than simple paths, in which the difficult sections were improved somewhat by building bridges and other works in order to cross the main rivers. These works were executed sometimes by the munificence of the kings, other times with funds provided by the towns or gentlemen who had a direct interest in communications, and in the greatest number of cases resorting to the system of personal service.

Looking at the degree centrality (defined as the number of connections of a town with others without intermediate steps), we see that the results by Madrazo Madrazo (1984b) for forty towns in 1720 based on post itineraries (Martínez de Grimaldo 1720) differ from that obtained through maps (Mortier 1710). Thus, in the first case, the average is 1.18 , and in the second it is 3.70 . Concerning the number of cities without documented connections, the result from the itinerary is $52.5 \%$ while on the map it is only $5.0 \%$. This means that the view mentioned above, claiming that a large part of the territory was disconnected from the rest and that the network was sparse, is highly questionable, because it is based on itineraries, implying much more subjective and fragmented information. The image that arises from our analysis and, in particular, from the integration of the maps of the time available shows a dense network of low-quality roads that differs little from early nineteenth century maps such as Quiroga (1811), Tofiño de San Miguel et al. (1823), de Cabanes and González Salmón (1829), and Thuillier and Barrière (1838), although, naturally, without the newly paved roads built from the second half of the eighteenth century.

\subsection{Enlightened reforms in communications and transport}

Once Philip V was consolidated in power after the War of Succession, a profound reform of the communication and transport systems was started according to the ideas of the Age of Enlightenment. It is important to point out that this reform involves two different processes, ${ }^{4}$ although with many points in common, in agreement with the fact that the administrative division was quite confusing throughout the eighteenth century. Reforms in the first area focused on improving the postal system and the displacement of elites and had a markedly legal and organizational character. On the other hand, a second, different reform process was aimed at reducing the costs of transport employing important investments in infrastructures. We now discuss these two processes separately.

\subsubsection{Postal reform}

The beginning of the eighteenth century brought about a profound transformation in the management of the Spanish postal system, imposed by the communication needs of an empire still of enormous dimensions at a time of great economic precariousness. To this end, in 1706 Philip V rescinded the postal monopoly of the Vélez de

\footnotetext{
${ }^{4}$ Postal and administrative layout and freight traffic layout were different (Madrazo Madrazo 1984a, b).
} 


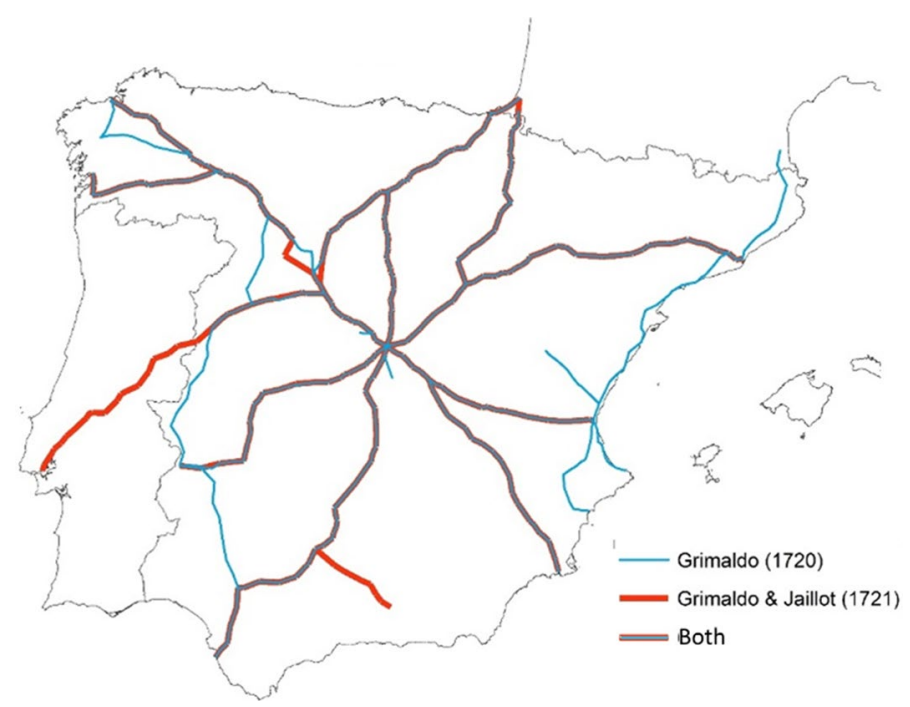

Fig. 2 Network changes arising from the 1720 regulations. Red, post roads preexisting this regulation that disappeared subsequently. Blue, post roads arising after the regulation. Gray, post roads preexisting the regulation that remained in use afterward. Map by the authors based on Martínez de Grimaldo (1720) and Jaillot and Martínez de Grimaldo (1721)

Guevara family, which, as descendants of the Tassis family, had held it since the sixteenth century. From that moment on, the post was managed by private individuals until 1716, when the position of Correo Mayor de España was abolished and the postal service became a centralized public service directly dependent on the Crown (Rodríguez González 1983), becoming an important source of income for it. Spain thus became one of the pioneering countries in managing the postal service from the State and a model for other European countries.

With the postal system fully in the hands of the Crown, in 1720 Philip V established the bases for its reorganization through the General Regulations for the Direction and Government of the Post and Post Offices of Spain. This document, in addition to other measures, includes a list of post roads of eminently radial structure and with a center in Madrid that followed to a large extent the main 'unmounted' post roads included in the 17 th-century guides, cf. Figure 2).

This hypothesis that the structure of the network of post roads was not an ex novo design, but was based on the preexisting structure, is confirmed by a map made by Jaillot on behalf of the Marqués de Grimaldo (Jaillot and Martínez de Grimaldo 1721) in which 'all the Ways and Posts of Spain are exactly collected and observed, following the Memoirs of the Major Couriers of Madrid.' Although the date of edition is 1721 , the information collected on the senders, and the fact that the information on the postage of the letters corresponds to those in force previously, suggests that it is a map that collects the situation of the network of posts before the promulgation of the 1720 regulation (Aranaz del Río 2005) and that it was commissioned by the Marques de Grimaldo to be used as a reference for its reform. With this caveat, we can now compare the Jaillot- Martínez de Grimaldo 

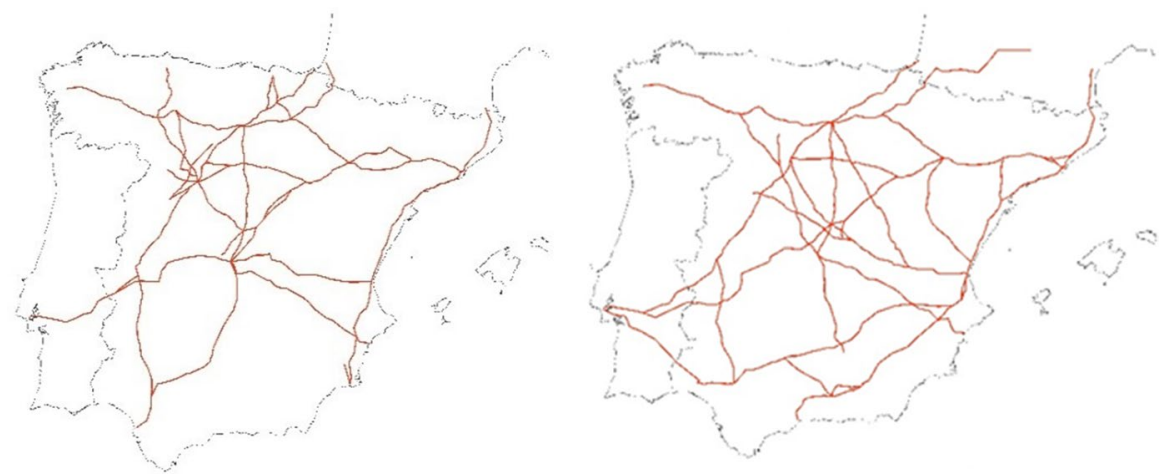

Fig. 3 Post roads of the seventeenth century. Italian couriers are the main source of information about the European post network between the sixteenth and the eighteenth centuries (Serra 2003). The information available from Codogno (1608), left, and from Miselli (1697), right, shows a structure similar to the one to be established by the 1720 regulations, with great axes connecting the center of the peninsula with the big cities in the periphery supplemented with several transversal axes. It can also be seen an east-west axis in the Ebro and Duero valleys that disappeared after 1720. Maps by the authors from the sources indicated above

map with the itineraries resulting from the Regulation. The comparison shows no increase in centralism, but, on the contrary, a less radial structure with the incorporation of two important north-south axes, one following the so-called Silver Way ('Ruta de la Plata' in Spanish, running close and parallel to the border with Portugal) and the other following the Mediterranean coastline between the French border and Alicante. The connection with Portugal via Ciudad Rodrigo and the branch to Granada was, however, excluded. For reference, Fig. 3 shows two maps of the post roads in the 17 th century, obtained from Italian couriers, showing a largely similar layout to the one arising from the Regulation.

To properly understand this discussion, it should be borne in mind that the definition of new post roads does not necessarily mean major changes in the structure of the road network, since it is only remodeling of the routes followed by the couriers to communicate post boxes with each other and thus transmit messages more quickly. This is apparent when we compare the post offices that appear on the map (Fer and Loon 1701), probably the first post map in Spain, with the routes that appear over time. It can be seen that, although the routes undergo great changes, the post offices are, to a large extent, the same (cf. Fig. 4). This largely virtual design of the post roads facilitates making profound modifications to the routes without major costs, as the location of the staging posts, the only physical element of the network, does not require major modifications.

The considerations above do not mean that the definition of the post routes did not have implications for infrastructures. As they were priority routes for the Crown, they received greater attention in terms of maintenance; on the other hand, as they were more traveled, they became safer and had better services (new inns), which generated a virtuous cycle that increased their relevance for transport. However, while the remodeling of the post network meant an important improvement in communications and the mobility of the most privileged social 
Fig. 4 Evolution of the post network (1701-1804). Time evolution is depicted from left to right and from top to bottom, with years indicated alongside the maps. Red lines indicate mounted routes, green lines unmounted routes, where mounted means fulfil all established requirements. Blue dots indicate post boxes in 1701 and the red dot is Madrid, showing that most of them remain on the roads despite the network evolution. The comparison between 1701 and 1821 shows that only 12 posts are isolated. The comparison between the 1701 and the seventeenth century network (cf. Fig. 3) shows the effect of the War of Succession on communications. The role of Madrid as the center of the network is enhanced and connections with the Crown of Aragón and with Portugal decrease, as a consequence of the larger presence there of Habsburg supporters. The fact that the Borbonic side is more effective in keeping control of the big coastal cities is reflected in the connections with those, that survive the war. The 1704 map, at the height of the war, is similar to the 1701 one, except for the restoration of the connection with Andalucía through Castilla La Nueva and the suppression of the connection to France via Valladolid, with two new axes connecting directly to Santiago and Burgos. This map points to a radial conformation of the network, that appears to be consolidating in the 1721 map, previous to the regulation issued that year and following seven years of peace. In agreement with this, the post network takes a very radial structure, while the transversal axes remain but reduced to the unmounted category. In 1775, the network is the most centralized one, as can be seen from the disappearance of the transversal axes. A less centralized structure is recovered in 1804, with the reappearance of routes like Silver Way (parallel to the Portuguese border), in Aragón, and the France-Portugal connection through Valladolid. In 1821, the process is completed and all routes have become mounted. Map by the authors based on de Fer and Loon (1701), de Fer (1704), Jaillot and Martínez de Grimaldo (1721), López de Vargas y Machuca (1760), Brion de la Tour and Desnos (1766), Espinalt y García (1775, 1804) and de Ayala (1821)

strata, it did not alter to a great extent the capacities of freight transport as tracks remained mostly unpaved.

\subsubsection{The road infrastructure plan}

In 1747, Ferdinand VI issued a Royal Decree creating the office of general superintendent of Couriers, Stations and Post Offices, in charge of the maintenance of roads and the construction of new ones, placing under the tutelage of the postal service the responsibilities that previously fell on the mayors and quartermasters. As an important novelty, regular financing was established for the development and conservation of the main road network at the expense of the Treasury (Martín Mora 2017). This change in the funding system was because the traditional system, based on local funding and obtained mainly through portazgos (entrance and exit tolls), was insufficient to undertake the intended expansion of the network (Bel 2011). As a result of this interest in improving the road network, the first roads were built in 1749, namely the Santander-Reinosa road and the Guadarrama pass.

However, it was not until 1761, with Charles III on the throne, that general legislation on the road network and public works can be considered as thoroughly established (Dirección General de Obras Públicas, 1856). The Royal Decree issued in 1761 to make straight and solid roads in Spain and to facilitate trade between provinces (de Gregorio - Marqués de Esquilache 1761) is a clear example of enlightened action to promote trade and development. It is a brief document of four pages in which it is decided the continuation of the canal of Castile and the construction of 'all the roads convenient for the common utility at the expense of the Royal Treasury, starting with the main ones from the Court to the Provinces, with a fixed assignment; that concluded these, all the others are implemented, that ensure the easy communication of some Provinces with others, and even of some villages with 
1701

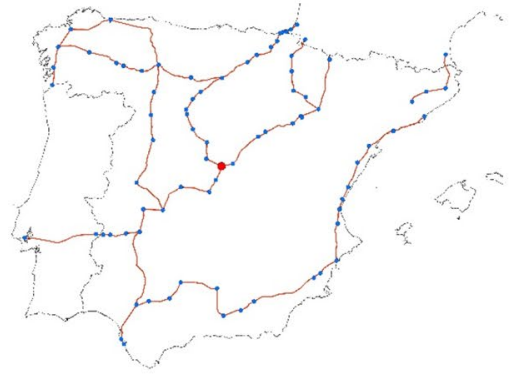

$1720 *$

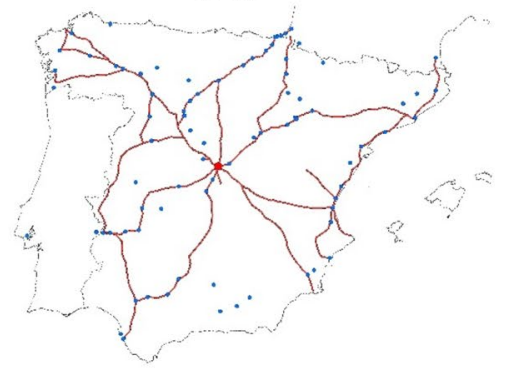

1766

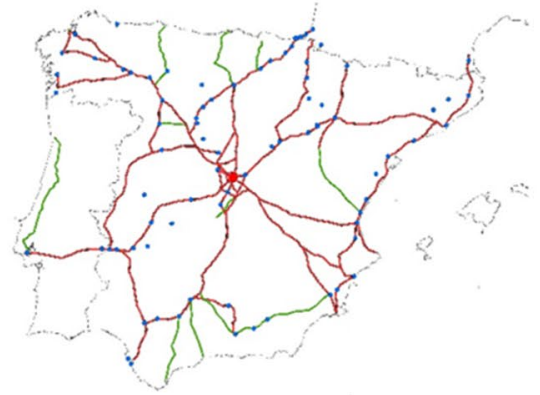

1804

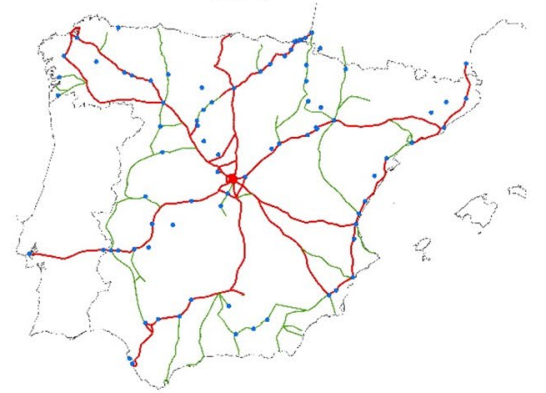

Post offices (de Fer 1701)

Madrid (main post office)

- Other post offices
1704

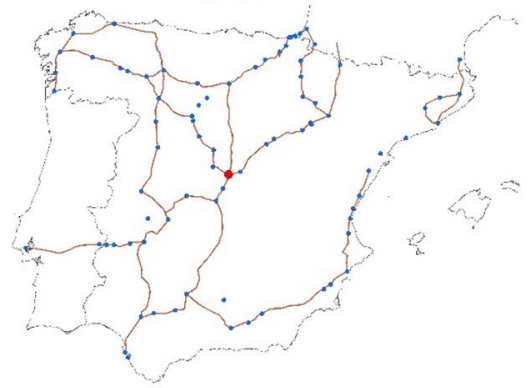

1760

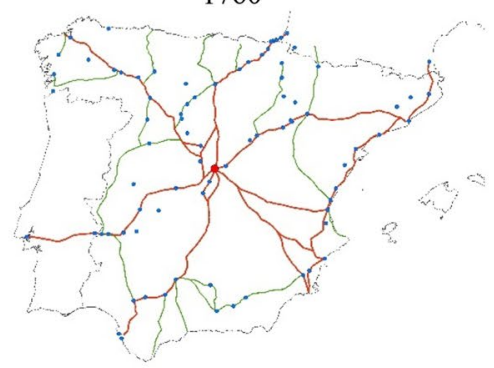

1775

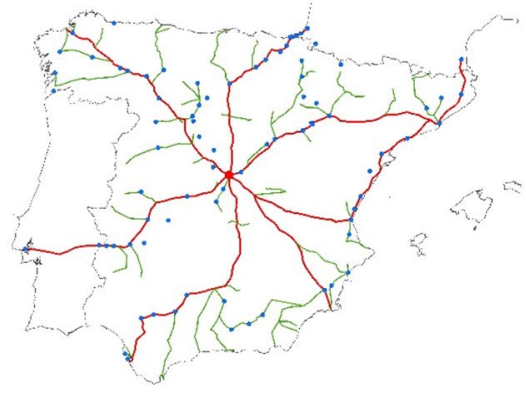

1821

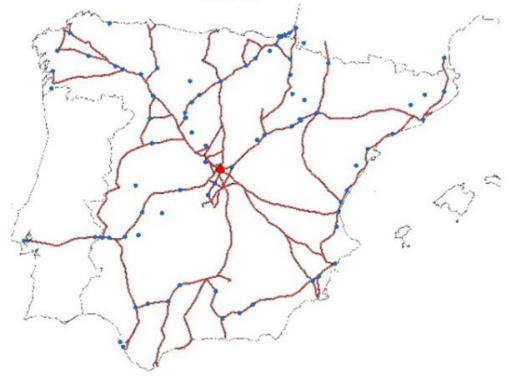

Post roads

Standard post roads

Substandard post roads 
others' (translation by the authors). This ambitious infrastructure plan began with the construction of the roads from Madrid to Andalusia, Catalonia, Galicia, and Valencia and the introduction, for its funding, of a national salt tax to which all people would be subject, 'ecclesiastical or secular, by duty, all contribute to an object that includes the common benefit' (translation by the authors). From 1761, Charles III and his successors carried out an intense infrastructure policy that laid the foundations of the current transport network.

In the 1761 Royal Decree, there is no evidence of a decision on the part of the monarch to build a radial network; instead, the Decree develops a desire to favor transport throughout the national territory. Indeed, at the time of Charles III's death, twenty-seven years later, the roads built could hardly be considered a radial network (de Ita and Xareño 1789; Madrazo Madrazo 1988). This does not mean, however, that the construction of all roads was considered to be equally urgent. During the years before the promulgation of the Royal Decree, there was an active academic and political debate on how to improve the Spanish transport network. The prioritization of communications between the capital and the periphery through straight roads as well as the funding of works by the Royal Treasury appearing in the Royal Decree of 1761 is largely the result of the influence of road arbiters who made society aware of the urgent need to improve the transport network (Madrazo Madrazo 1974).

Thus, de Quintana (1753) proposed the creation of a network of radial roads, starting from the main ports converging in Madrid, and another transverse, distributed throughout the kingdom, which would allow a very significant reduction in transport costs. Unlike other projects of the time, de Quintana's proposal focuses on the means of transport, the ox cart, and the logistics system. He designed a network in which every 3 or 4 leagues oxen would be replaced to achieve greater speed and load capacity, similar to the way horses were replaced on post roads to increase the speed of letters and travelers.

Two years later, Fernández de Mesa, with his Legal and Political Treaty of Public Roads and Inns (Fernández de Mesa 1755), contributed ideas on funding that complemented those already appearing in the Royal Decree of 1747 . He proposed that the construction and maintenance of the roads should be covered by those who benefited from them, mainly municipalities, but also by the lords and the Church, something quite controversial at the time. The Crown should only contribute to the royal roads 'for being the Prince's and enjoy in them the protection, and jurisdiction as well as the usefulness of facilitating the prompt expedition of his orders, Posts and military functions' (translation by the authors).

Along similar lines, Miguel Sarmiento had a deeply centralist vision, in which the capital had to play a fundamental role in the territorial structuring of the nation (Reguera Rodríguez 1999). Using a purely geometric perspective, he proposed a network of 32 radial roads from Madrid to the most remote parts of Spain in imitation of the military routes of the Romans (Sarmiento 1757). The roads should be straight, avoiding the towns, so if any were on their way they should surround them. Interestingly, this non-urban design will be used centuries later for the development of the German motorways. To avoid the congestion that would occur in Madrid, as the 
center of the network, he proposed the construction of a circular road to distribute the traffic, in a similar way to the motorways that now surround the cities.

One of the reports that probably had the greatest influence on the subsequent development of the road network is the Economic Project, which introduces various measures aimed at promoting the interests of Spain, written by Ward in 1760 and published posthumously in 1762 (Ward 1762). Among his indications for a better government of the country, he dedicates two chapters to the improvement of transport. However, his attention is very focused on the development of river navigation, dedicating only four of the fifteen pages devoted to this subject to land communications, two of them referring to funding aspects. In general, he considers roads as a subsidiary system to the river (translations by the authors): 'Since there can be no navigable rivers or canals everywhere, good roads have to make up for this lack.' It is therefore not surprising that the road needs were limited to 'six major roads, from Madrid to La Coruña, to Badajoz, to Cadiz, to Alicante and the line of France, as well for Bayonne's part as for Perpignan's part' as the transversal connectivity was covered by rivers and canals. The choice of these roads was probably based on the importance that these roads had historically had and on the use that was made of them at that time as post roads. These radial ways should be complemented by 'different ways of crossing from one city to another, and making the King the first cost (as befits) is very just, that henceforth the ways be maintained by the villages themselves who will enjoy the benefit of this providence.' Like Sarmiento, Ward emphasizes the importance of the straightness of the roads 'at the cost of any difficulties' because the reduction of the distance compensates with time the higher initial costs.

The orientation of the infrastructure plan toward achieving full national connectivity, although generally accepted in the technical and political fields, was not, however, exempt from criticism (Reguera Rodríguez 1999). Jovellanos, in its Report on the Agrarian Law (de Jovellanos 1795), considered that it would have been more beneficial to encourage economic activity to improve local connectivity rather than to build major national axes and not to start new projects before those already started have been completed.

\section{The road network}

With the historical review of the development of the Spanish road network and its evolution in mind, we now turn to a quantitative study of the most relevant issues related to it.

In recent years, profound changes are taking place in the social sciences. The increase in computing power, the availability of more sophisticated software, and the growing accessibility of digitized primary sources mark the beginning of an era of huge methodological changes in the field of economic history. The decreasing costs of mass digitization of maps and other primary sources together with the development of character recognition systems including handwriting thanks to deep learning make it possible to analyze information that until recently was inaccessible or at least untreatable. Thanks to these new possibilities, quantitative analysis and economic theory can be combined to advance our understanding of history in new 
ways (Wehrheim 2019). This is what Mitchnener calls 4D economic history, Digitally Driven Data Design. The development of 4D has the potential to cover more areas and in greater depth than the exploitation of IPUMS, the integrated public use microdata series has been done so far (Mitchener 2015). On the other hand, a major contribution to this toolbox has been the geographic information systems (GIS) that, by incorporating the time dimension, have become very useful in the field of social sciences (Gutmann et al. 2018). GIS consists of an integrated database management system with a mapping tool that allows easy representation of data using maps but also integrates scattered information using location as a nexus and analyzes data spatially. This has allowed historians to handle data with a spatial component in a more powerful and sophisticated way than was common in the past (Healey and Stamp 2000; Ell and Gregory 2001) especially in the field of transport (Atack 2013; Perret et al. 2015).

Often, in Economics, interdependencies between the different aspects of the phenomena studied are not adequately considered (Schweitzer et al. 2009), which is a major weakness since the relationships between entities matter whether they are people, objects, ideas, or anything else (Brughmans 2013). Rather than focusing on these entities in isolation, the network perspective allows for an explicit examination of these entities to properly understand their behavior (Wasserman and Katherine 1994; Watts 2003; de Nooy et al. 2005). This is particularly common in the area of infrastructures, not just transport, where very often the analysis focuses on differences in regional endowment without taking into account that effects, both positive and negative, may occur far from the location of the entity. Space is not just an additional element of the economy: It constitutes, as Reggiani and Nijkamp (2009) say, an intrinsic feature of any geo-economic system and can give rise to the emergence of complex nonlinear and interactive behaviors and processes in a geographical environment. Network analysis allows to overcome these limitations by making these relationships explicit and enabling global analyses of the phenomenon using widely contrasted mathematical tools. To this end, we have made a thorough effort to establish a correct network representing the roads, beginning of course with the proper starting point, namely the situation at the turn of the 18th century.

As there is no suitable cartography for this purpose, it was necessary to compile it from the dispersed information available. Valk's (1704) map was chosen as the basis for our reconstruction because it has the greatest regional connectivity among those elaborated in the first years of the century. As this map was made taking into account the most important connections between cities, it suffered from a certain lack of national integration through long-distance connections, a problem we solved by resorting to the itineraries of Anonymous and Pontón (1705) and de B. F. and de Grieck (1704). It would have been desirable to integrate all available road information, but it would have resulted in an excessively complex network for simulations; at the same time, we are confident that the so-obtained network is a fairly accurate description of the roads in the early eighteenth century.

As we mentioned above, maps from this period showed a distorted view of the road network by incorporating some errors in the location of cities and towns (planimetric problems), but this can be rectified if there are no spatial inconsistencies (topologic problems). This issue can be more easily understood by looking at Fig. 5, 


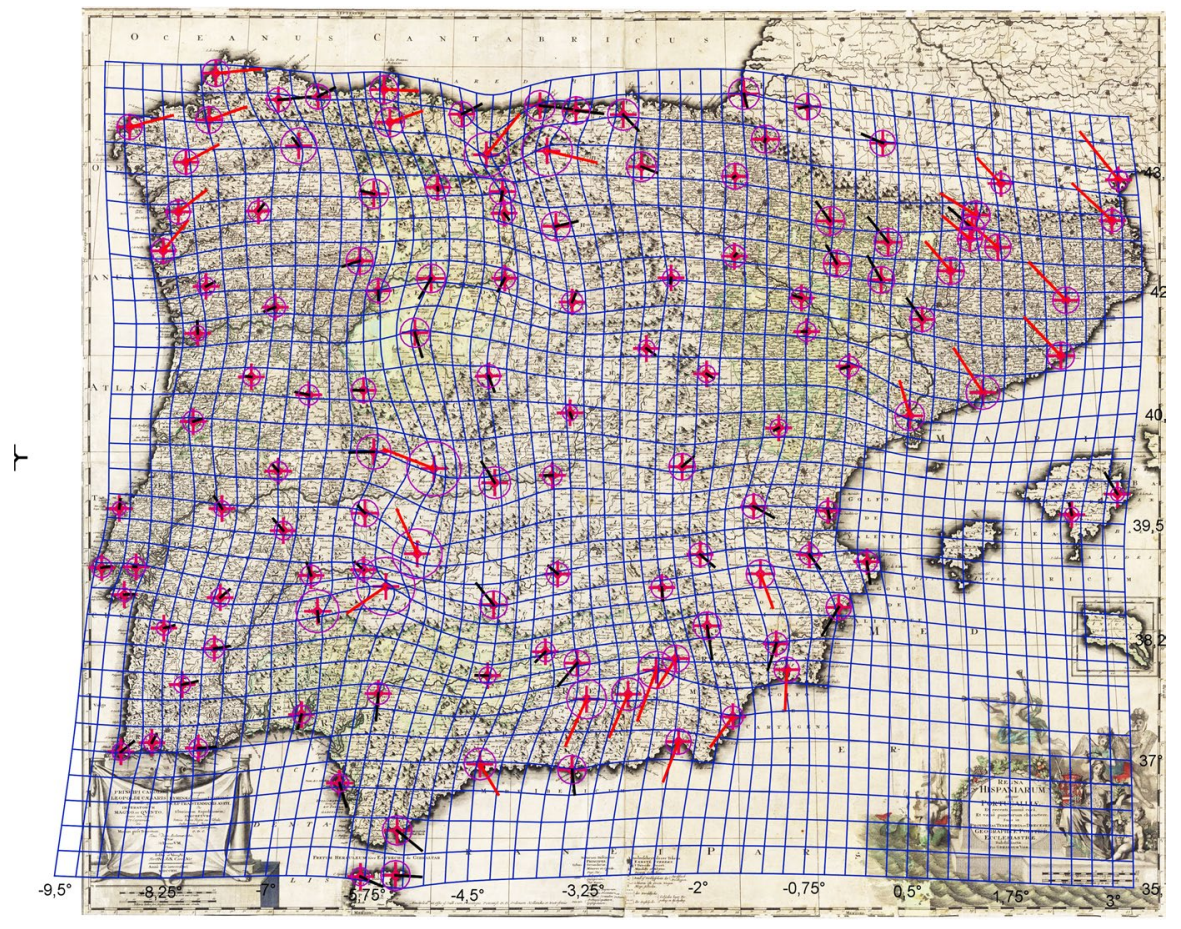

Fig. 5 Cartographic errors on the Valk (1704) map. Source: own elaboration using MapAnalyst (Jenny and Hurni 2011). Red and black lines are vectors of displacement joining points in the old map with the right location on a modern reference map. The distortion grid shows the errors of the map. Compressed or enlarged grid cells reflect the problems in the old map

which shows the spatial distortions of the Valk map by comparing the location on the map of the main cities with what they should have.

If the map were correctly drawn, the mesh of distortions would show a homogeneous structure. The errors are planimetric because the mesh, albeit deformed, is not twisted, which would imply the existence of topological problems.

The biggest problem, shared by other maps of the time, arises in Catalonia, which appears too much to the east. Other areas with planimetric errors are eastern Andalusia, Extremadura, Galicia, and Asturias. These errors in the knowledge of the reality of the territory could have influenced the design of the network by making politicians think that the distances between the cities were different from the real ones. However, the availability of real travel times in the itineraries could have mitigated these potential biases.

To do this, all the villages that appeared on Valk's map and on the itineraries of Anonymous and Pontón (1705) and de B. F. and de Grieck (1704) were accurately represented on a modern map and the sections of road that appeared in those sources were represented by straight lines. Straight lines were used due to the limitations of available information. The itineraries do not indicate 


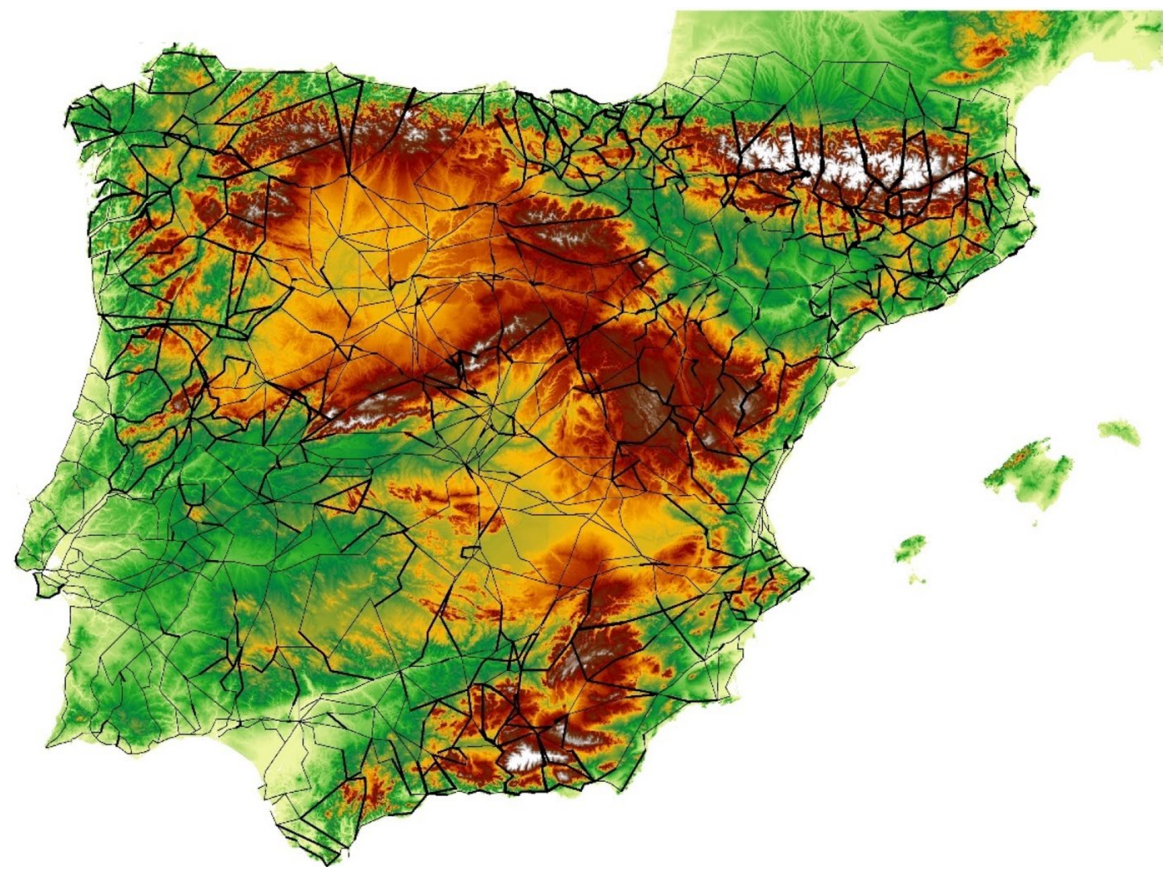

Fig. 6 Network of Iberian roads at the beginning of the eighteenth century. Map by the authors following the method detailed in the text. Line thickness is proportional to the roughness index of the corresponding road. This is the network taken as a reference in the remainder of the paper

intermediate points between towns, and the routes marked on the map were not reliable due to underlying representation errors. This could lead to the introduction of serious errors in the assessment of the actual distance between towns and consequently of transport costs by not considering the slopes and curves of the roads. To reduce this problem as much as possible, it was assumed that the error between the actual distance and the distance in a straight line was proportional to the roughness of the terrain covered. An approximation of the actual distance was thus obtained by multiplying the straight line distance by a roughness index.

Unlike what is usual, our index, instead of being based on the general characteristics of the territory (Riley et al. 1999), focuses on the trajectory followed by the road. Areas with high roughness may have passes that are easily passable, and that surface-based measurements are unable to incorporate. The construction of the index is simple and intuitive: the number of contour curves crossed by the path divided by the length of the section. In this way, it is possible to overcome the lack of precise information about where the road really passes through. If the road is direct, it has greater slopes and cuts more contour curves, if on the contrary, it makes a detour it is longer but cuts fewer contour curves. Figure 6 shows the network finally considered. We want to stress that this is an important result of our research in itself, given our comprehensive historical reconstruction. 
To proceed with our long-term analysis, we need to assess whether or not the so obtained network remains stable. In other words, there should be no major changes in the connectivity of the territory beyond the improvement of the road sections included in the infrastructure plan under analysis. Confirming that this hypothesis is correct is difficult given the lack of detailed information on the network and its evolution, since until the final third of the nineteenth century there was no official national route map with the necessary level of detail (Depósito de la Guerra 1865). However, the fragmented information available seems to indicate that changes in second-order roads were of little importance, maintaining throughout the period a dense network, homogeneous in density, and low quality.

Further evidence supporting this conclusion comes from the use of road guides as a reference. In this regard, we observe, on the one hand, that the work of Escribano (1758) was published continuously, and with hardly any modification, from the third edition of 1767 until, at least, 1823, which indicates that the network did not suffer great alterations in its layout, since the guide did not lose interest for the public. On the other hand, based on this guide, López (1809) published four editions in which he completed and corrected the information contained, but without including any new routes, except in the last edition, dated 1828, in which, in the case of Catalonia, he incorporated fifty new roads, many of them paved. This confirms the stability of the network and also that the low road density of the peninsular periphery that appears in the guides is not real, but is due to the lack of information and the special interest in the capital's connections, as shown in their titles. ${ }^{5}$ Interestingly, the comparison of the network presented by Escribano and López with the anonymous work published in Valencia in 1810 with military motifs (Anonymous 1810) (Annex illustration A2) shows us quite similar information, although not always coincident. There are discontinuities in some paths that disappear when the sources are integrated, which indicates that they are incomplete sources that can lead to errors if considered in isolation.

It is important to mention at this point that, in terms of road cartography, there was an important void during the second half of the eighteenth century in which practically only post routes were included in the maps. Only at the beginning of the nineteenth century, the needs of military logistics brought up new maps and itineraries. During the War of Independence (Lópéz de Vargas y Machuca 1808; Nantiat et al. 1810; Picquet et al. 1810) and the campaign known as 'The 100,000 sons of Saint Louis' (Guilleminot et al. 1823), foreign armies that operated in Spain carried out cartographic works that represented an important improvement to the national maps (Puyo et al. 2016). These military maps have advantages over official ones such as those of de Cabanes and González Salmón (1829) because they are based on direct inspection of the quality of roads instead of administrative classifications. The network shown by these maps is qualitatively similar to that observed in those made a century earlier during the War of Succession: a dense network, fairly

\footnotetext{
5 In the 1790, 1796 and 1823 editions of Escribano's guide, the explicit reference to the capital 'Spanish itinerary or road guide, to go from Madrid to all the cities of Spain' was removed to indicate that these new versions included also information on the routes to other European courts.
} 
homogeneous in its distribution and with a generally low quality of roads, especially in mountainous areas. For this reason, we consider that the network we have inferred from the map of Valk (1704) is a good approximation of the road system of the 18th century and the first part of the nineteenth century.

\section{Results}

Before presenting our results, we must discuss a potentially important shortcoming of our work, namely the limitations of the available statistical sources that constrain ourselves to consider domestic inland road traffic only. Therefore, we are not including the effects on road transport flows of trade at the borders with France and Portugal nor does it cover both cabotage and long-distance maritime traffic. However, we consider that the biases introduced are smaller than what could be expected a priori due to several reasons. To begin with, although incomplete, part of the effect has been included in the analysis to the extent that in the long-term port and border traffic has an impact on the size of cities due to increased commercial activities (Lee 1998; Galor and Mountford 2008). On the other hand, despite the lack of reliable statistics, it can be accepted that Spain's trade with France and Portugal and in general with the rest of the countries was rather limited in the eighteenth and early 19th century (Bairoch 1974; Prados de la Escosura 1986, 2015; Moreira 2006). As for colonial trade, it was important in terms of value (Cuenca-Esteban 2008) but not so much so in terms of tonnes transported. If compared to the traffic of national products, the impact on traffic in the network is small (Anes 1983; Delgado Ribas 1986; Oliva Melgar 2004). Also, the Spanish merchant fleet at the beginning of the nineteenth century (Lobeto Lobo 1989; Dubert García 2008) was of small size compared with the land transport capacity for the period before 1750 offered by Madrazo Madrazo (1984a). Another relevant aspect of this issue is that the disadvantages of land transport compared to navigation were not as extensive as is usually claimed (Carreras Monfort and de Soto 2010; Scheidel 2014). A natural experiment of the real advantages of ship transport versus land transport in the eighteenth century is given by the Canal de Amposta. This channel, whose stated objective was to facilitate Aragon's trade with America, was begun in 1778 and would have made river Ebro navigable up to some $450 \mathrm{~km}$ by saving the problems of navigability of the Delta. The project was abandoned, however, 5 years later, when it became clear that the high maintenance costs of just $10 \mathrm{~km}$ of the canal or the alternative ground portage did not compensate for the potential savings in transport costs (Franquet Bernis et al. 2017). About cabotage, several authors highlight its limited relevance as a means of transport compared to land transport (Frax 1981; Martínez-Galarraga 2013). Finally, the few references to ship transport in the itineraries (Anonymous and Pontón 1705; Escribano 1758; López 1809; Anonymous 1810) and travel books (van der Aa and Jordan 1700; de Laborde 1808) of the eighteenth and nineteenth centuries suggest that it was of little relevance. 


\subsection{A design with deep historical roots}

Having made a precise description of the Spanish road network at the arrival of the Bourbon dynasty and the investments made in the following 150 years in the previous section, we can establish that there were no major alterations to the structure of the network. No new routes were created using large bridges or tunnels, but simply improvements to some of the preexisting roads. In quantitative terms, the interurban road network in the period analyzed was about 150,000 km long, of which only about $6000 \mathrm{~km}$ were improved, representing a percentage of approximately $4 \%$.

We can now use our approach to answer the previously stated hypothesis about the road structure in Spain.

We begin by studying the H1A hypothesis relative to whether the radial design of the newly paved roads proposed by Ward and materialized in the Royal Decree of 1761 was an entirely new model or, on the contrary, a simple evolution of the preexisting network. To test this hypothesis, an obvious key requirement is the knowledge of the road structure inherited from the Habsburgs.

As discussed above, we have quite detailed information about the distribution of roads, thanks to the road maps, but we do not know how the traffic of people and goods was distributed among them because until the second half of the eighteenth century the categories of roads (horseshoe, wheels, etc.) are rarely explained in itineraries or maps. An important exception is the map of Spain included in the Itinerarium Orbis Christiani, (Matal and Hogenberg 1579), considered the first European atlas of roads (Wertheim 1935; Lang 1950; Schuler et al. 1965) in which the main roads and some of the secondary roads can be seen separately. As it is a road atlas of continental level, it can be assumed that the few roads it incorporates are the most important ones. It has to be stressed that the concept of importance must be understood from transport flows since road quality was very low in the whole Spanish network. The Matal and Hogenberg map (1579) presents a radial structure that differs widely from the decentralized network that appears in the Villuga (1546) and de Meneses (1568) itineraries mentioned earlier: Instead, roads are organized around six main roads that emerge from the center of the peninsula and which coincide, to a large extent, with those that would be proposed almost two centuries later (Ward 1762) as the basis for the design of the road network approved by Carlos III in 1761 (de Gregorio - Marqués de Esquilache 1761).

This is an important result because it strongly suggests that the structure of the Spanish road network did not emerge ex novo with the arrival of the Bourbons after the War of Succession. The network had already emerged at the end of the sixteenth century, without direct state intervention, as a consequence of the orography and the relative positions of the cities and towns (topological relations), and, as a consequence of this, of the movement of people and goods itself. In this way, the eighteenth-century road arbiters who defended a radial network only formalized a road structure that already existed de facto.

To confirm the reliability of the network structure shown by Matal and Hogenberg (1579), we have compared it with the information available for two different 


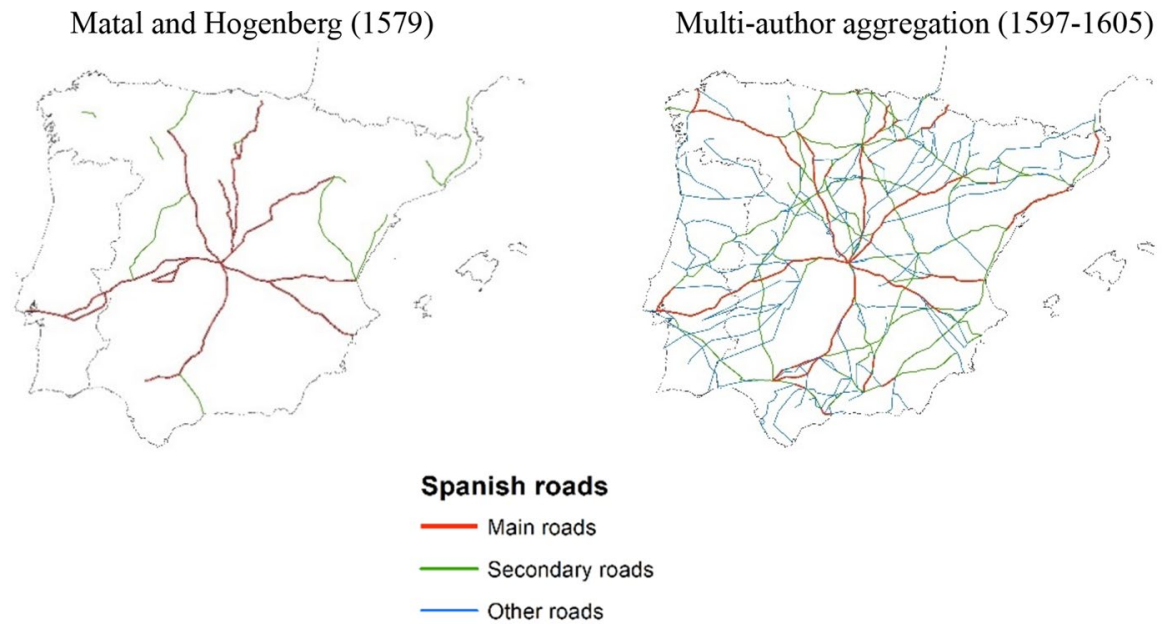

Fig. 7 Radial structure of the network of roads at the end of the sixteenth century and the beginning of the seventeenth century. Left: Matal and Hogenberg (1579). Red continuous lines, main roads; green dotted lines, secondary roads. Right: Andree (1597), Quad and Eichovio (1604), and de Mayerne (1605). Red, roads recorded in all three sources; green, roads recorded in two sources, and blue, roads recorded in only one source. Map by the authors based on the quoted references

periods (1544-1579) and (1597-1605). ${ }^{6}$ To this end we assume, as Menéndez Pidal (1951) and Braudel (1976) did, that the most important roads should tend to appear in a greater number of sources. In this way, the different categories of road sections are established according to the number of times they appear in the sources consulted. As can be seen from Fig. 7, the results of our analysis confirm the map of Matal and Hogenberg (1579) showing a radial network with center in Toledo.

The fact that all the available sources taken together grant Toledo a central position in the sixteenth-century road network, despite not having a continuous court or an especially large population, seems to be related to some clear locational advantages. These advantages would mainly come from its position in the center of the Iberian peninsula, the physical characteristics of the territory, and its relative position concerning the rest of the large cities. It is worth noting that Villuga's and Meneses' itineraries also imply certain support for this radial view of the network if we consider that the sections that appear repeated on the most occasions are also the most important or frequented (Menéndez Pidal 1951) (cf. Figure 8). Therefore, our study establishes that Toledo was the center of the network and, therefore, channeled a large part of the transport flows (Braudel 1976). Crucially, the establishment of the capital in Madrid in 1561 would only mean a slight modification of the network in

\footnotetext{
${ }^{6}$ Only national road information is included, thus excluding local information and postal guides, as couriers could follow routes that were not possible for the transport of goods. For the period 1544-1579, the sources used were D'Ocampo (1544), de Villuga (1546), Estienne (1552), Gail (1563), Stella and L'Herba (1564), de Meneses (1576), Rowlands (1576), and Matal and Hogenberg (1579) and for the period 1597-1605 Andree (1597), Quad and Eichovio (1604), and de Mayerne (1605).
} 


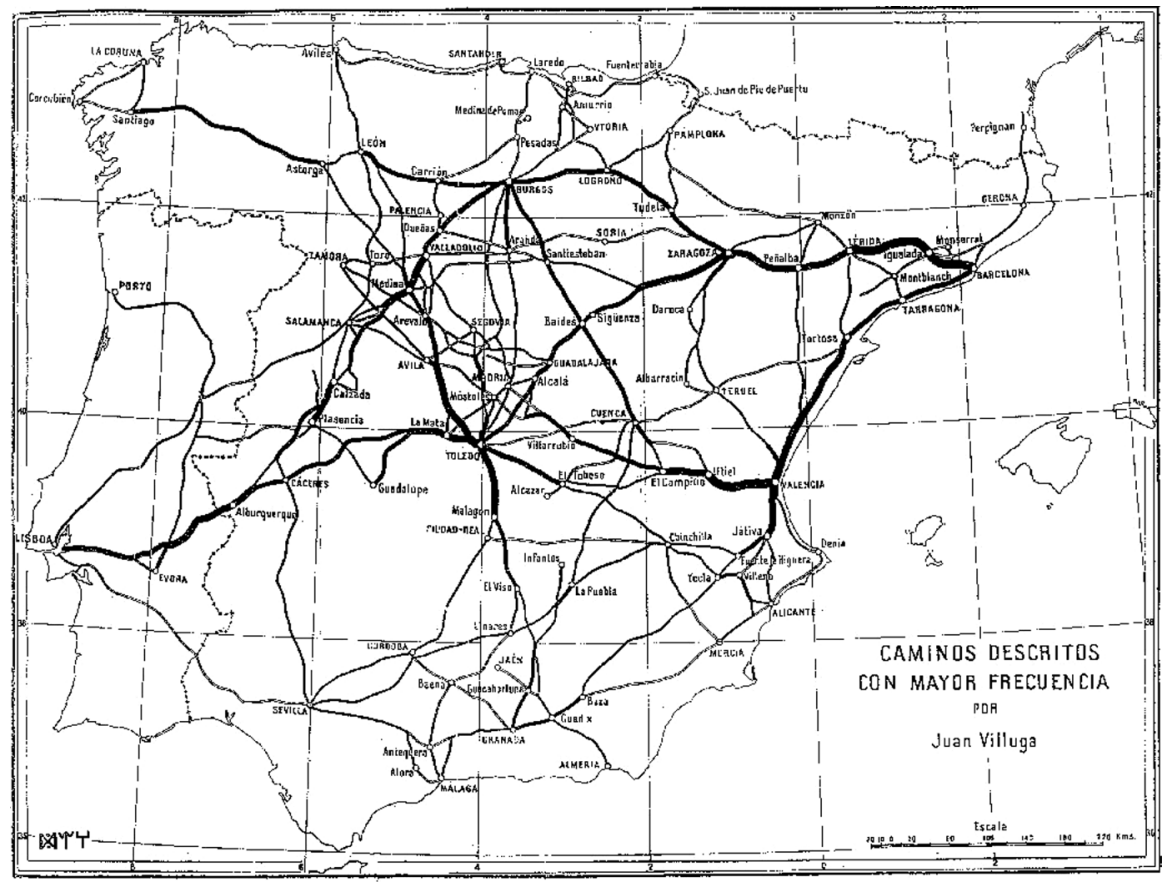

Fig. 8 Roads most frequently described by Pedro Juan Villuga. Source: Menéndez Pidal (1951)

the successive decades, especially about the roads of Extremadura and Valencia that would no longer pass through Toledo. In any event, this change has no implication on the H1A hypothesis of our study: According to the evidence presented above and the comparison of the road network established in Sect. 3 with the data about the preexisting network, we have to conclude that the radial structure of the Spanish road system can be traced back to the middle sixteenth century, and therefore, it cannot be considered an ex novo design.

Let us know analyze hypothesis H1.B that states that the changes in the road network are linked to the Enlightenment vision of the State that came with the Bourbon dynasty (Madrazo Madrazo 1984b; Bel 2010) and that can only be sustained if changes in the network occur in subsequent years. Figure 9 shows the changes in weighted road density between 1600 and 1766. As can be seen, two-thirds of a century after the establishment of the Bourbon dynasty, the network remained virtually unchanged to the situation during the Habsburg dynasty so hypothesis H1.B cannot be accepted: changes in the road network are not linked to the accession of the Bourbons to the throne. Most of the changes in the network must be placed after 1800 of which the Enlightenment is not a part. In general, it can be seen that the modifications are not very important and are distributed throughout the territory. The most affected areas can be seen in graph $c$ where the changes are directly represented. The fact that the changes in the network density were basically local suggests that modifications of the road structure of Spain impacted many more cities than regions. This is an important issue, also included in our hypotheses, that warrants more discussion in the next section. 
(a) Weighted density of roads in 1600

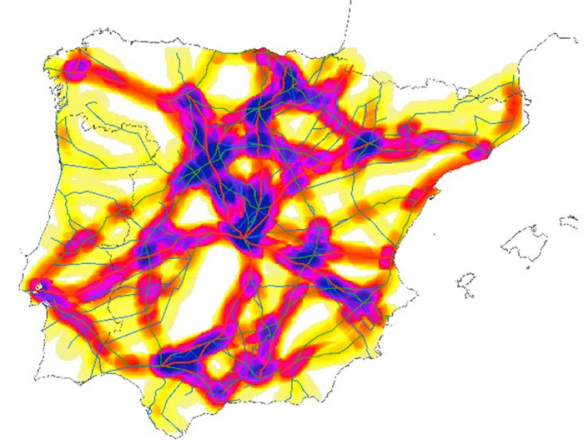

(c) Variations in weighted density of roads between 1600-1766

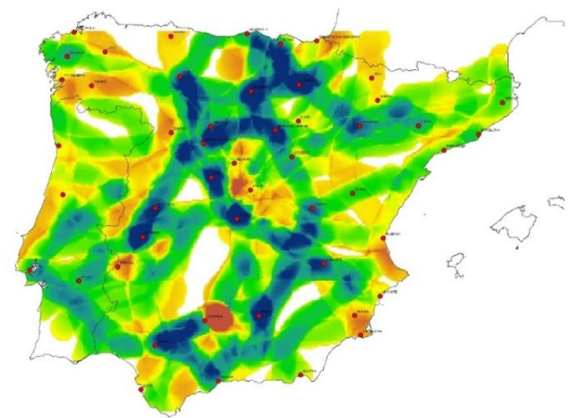

(b) Weighted density of roads in 1766

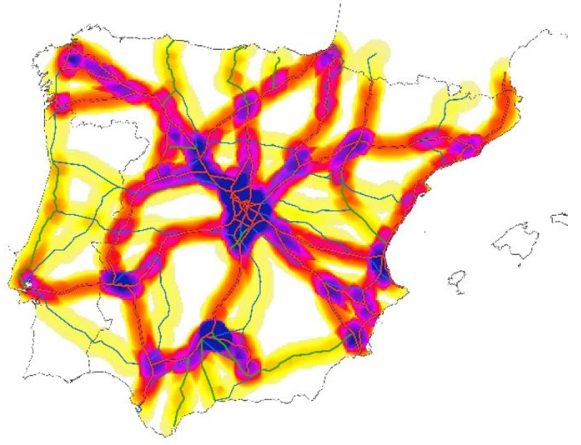

Road density (maps a and b)

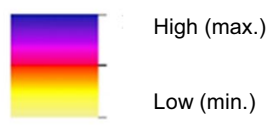

Variations in road density (map c)

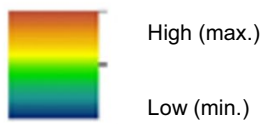

Fig. 9 Road density (1600-1766) and its variations. Panel a shows the weighted road density circa 1600; panel b shows the same magnitude in 1766; and panel c depicts the difference between 1600 and 1766. Weighted road density takes into account the number of roads and their category in $50 \mathrm{~km}$ around every point. Main roads are weighed double than ordinary roads, secondary roads are weighed 1.5 times ordinary roads. Map by the authors based on Andree (1597), Quad and Eichovio (1604), and de Mayerne (1605) and Brion de la Tour and Desnos (1766)

\subsection{A design with little impact on the comparative advantage of regions but a large impact on cities}

The next issue that we address in this paper is the claim that the road network was designed by the Bourbons to improve the communications of Madrid with the periphery instead of activating the growth of the interior regions (Ringrose 1972). For a rigorous consideration of this question, we recall that there were three hypotheses to test. The first (H2.A) relates to the magnitude of the effects generated by the road plan 'The newly paved roads produced important changes on the mobility of the territory.' The second (H2.B) refers to the homogeneity of the regional distribution of its effects 'The positive effects of the construction of the newly paved roads were concentrated in a few regions, mainly Madrid and the coastal regions, which was a comparative disadvantage for the inland regions' (Ringrose 1972, Herranz-Loncán 
1780

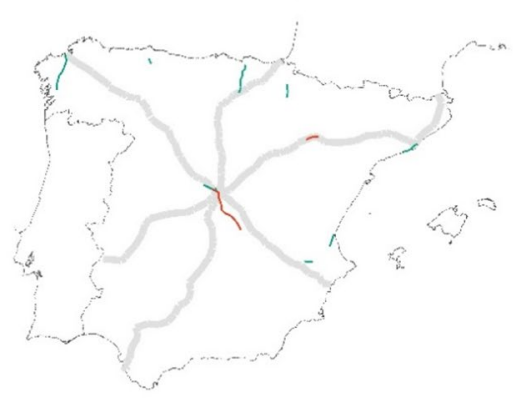

1820

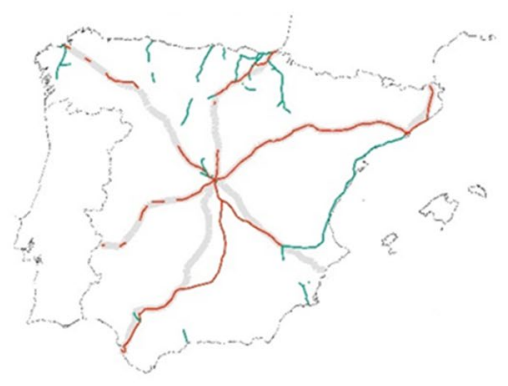

Ward roads (1760-1762)

Big roads
1790

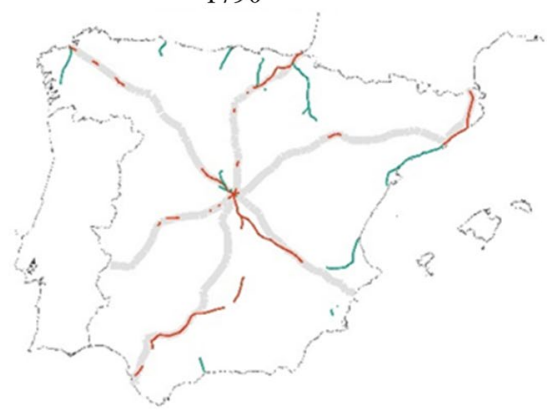

1850

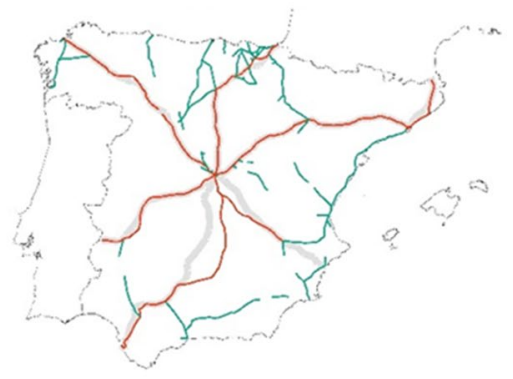

Roads

Transverse roads

Radial roads

Fig. 10 Evolution of the network of paved roads (1750-1850). Gray, the six main roads proposed by Ward in 1760, constituting the basis for the radial road structure. Red, other roads that can be considered part of the same radial structure. Green, transversal roads. Dates of completions are approximate. Map by the authors based on Madrazo Madrazo (1984b)

2006). Finally, the third (H2.C) considers the scope of the effects 'The effects were mainly at the level of cities, not so much of the regions.'

Regarding the magnitude of investments in roads, undoubtedly, the long reign of Charles III and the first part of the reign of Charles IV was important, but not so much from results. Indeed, after the successful completion of the roads through Guadarrama and from Reinosa to Santander by Ferdinand VI, the period that continues until the end of the 18th century is disappointing, despite the significant resources spent from the salt tax. After half a century of intense activity, it had not been possible to build even half of the main roads, and most of the roads considered completed were impassable. In some cases, this was due to poor maintenance, and in others directly due to the application of inadequate construction techniques (Betancourt 1868). Such poor results are the consequence of three factors: the bad organization resulting from the lack of unity in management, the shortage at all levels of qualified labor, and the lack of financial resources, not only due to a lack of income 
Table 1 Construction activity and radiality of the new paved road network. Source: Own elaboration. The data are an approximation of the reference years based on the data provided by Madrazo Madrazo (1984a) which includes roads already built and in the process of being completed

\begin{tabular}{lllccc}
\hline & 1750 & $1750-1780$ & $1780-1790$ & $1790-1820$ & $1820-1850$ \\
\hline Radial Km. & 14.3 & 164.5 & 1025.5 & 1086.5 & 543.0 \\
Transversal Km. & 58.6 & 340.6 & 498.5 & 775.6 & 1539.4 \\
Total Km. & 72.9 & 505.1 & 1524.0 & 1862.1 & 2082.4 \\
Km. per year & - & 16.8 & 152.4 & 62.1 & 69.4 \\
Radiality index (RI) & $19.6 \%$ & $32.6 \%$ & $67.3 \%$ & $58.3 \%$ & $26.1 \%$ \\
Acumulated RI & $19.6 \%$ & $30.9 \%$ & $57.3 \%$ & $57.8 \%$ & $46.9 \%$ \\
\hline
\end{tabular}

but also to inadequate control of expenditure (Dirección General de Obras Públicas 1856, Reguera Rodríguez 1999).

However, in 1799 a General Inspectorate, first assumed by the Count of Guzmán and later by Agustín de Betancourt, was created, along with a School for the training of the members of the new Corps of Engineers of roads and canals of the Kingdom. The results of these measures were extraordinarily positive, increasing construction activity to an average of more than $300 \mathrm{~km}$ per year until the beginning of the War of Independence in 1808. This armed conflict caused great destruction of the infrastructures and a serious setback in their development that persisted, with different ups and downs, until the middle of the nineteenth century. In this scenario, one has to look only at the speed with which the network developed to conclude that the relevance of improvements in transport infrastructures was very little in a large part of Spain until well into the nineteenth century (cf. Figure 10).

For a more quantitative discussion, we consider a network more or less radial as a function of the percentage of transverse connections it contains. In Fig. 10, the built sections corresponding to the six radial axes defined in the Royal Decree of $1761^{7}$ have been marked in red and the rest in green. It can be seen how, during most of the period analyzed, the kilometers built of transversal roads surpassed those of radial roads (Table 1). This is confirmed by the radiality index, defined as the quotient between the built kilometers of radial sections and the total, that shows that the period of maximum radiality coincides with the central phase of the network expansion. As the expansion is completed, the radiality decreases. Furthermore, these results overestimate the construction of radial roads insofar as the connection with the center was not achieved. Looking at, for example, the Barcelona-La Junquera section as radial is questionable when work has barely begun between Madrid and Barcelona. The greatest centralizing effect of construction on the network corresponds to the period 1790-1820. Until 1790, most new roads were built on the periphery and were not interconnected, with the result that most of the benefits

\footnotetext{
7 Neither the Real Decreto of 1761 nor the report by Ward in 1762 have a detailed description of the proposed roads, and therefore, we take as reference the map with the post roads by López de Vargas y Machuca (1760).
} 
remained in the different regional areas. Only after 1820, the closure of the links between the radial roads began to redistribute territorially the improvements in mobility.

We thus see that the transversality of the network is not invariable, but rather it depends on time and the frame of reference. The network, seen as a whole, is a fairly homogeneous mesh that cannot be considered radial. However, the situation changes if we consider the importance of connections for people, both from transport flows and the quality of infrastructure. For the flows, a radial structure centered on the middle of the peninsula was observed from the sixteenth century onwards, although there were no notable differences in terms of the quality of the roads. With the Bourbon road plan, the paving of the busiest roads was improved. The sequential implementation of the network generates temporary distortions in the relative quality of the roads that alter the flows and, therefore, the commercial advantages of the towns located in it. As we discussed in the introduction, such variations in advantages can be consolidated, remaining after the network is completed and the differences in infrastructure provision disappear. Network analysis tools, applied to our rich dataset, make it possible to quantify the effect of these changes on the logistical advantages of the territories using two main indicators: accessibility and betweenness centrality (Barthélemy 2011).

We address first the accessibility, defined as the closeness centrality of each city, which is, in turn, the inverse of the sum of transport costs to all other cities of the network through the optimal paths. Being an unweighted measure, it has few information requirements but has the disadvantage of considering transport costs for all destinations equally rather than focusing on those with more intense relationships.

An accurate assessment of the effect of road improvements on transport costs would require detailed knowledge of the percentage of different uses on each road section. Unfortunately, this information does not exist so it must be established based on indirect information. Therefore, we have used an approximate value of $25 \%$. We think this value fits a wide variety of situations. Horse-drawn couriers can benefit greatly from improved road surfaces while a heavy ox cart on many stretches would not appreciate the difference in speed because the restriction is made by draft animals. A $75 \%$ time saving from improving a mountain pass becomes only $7.25 \%$ if the road section is $100 \mathrm{~km}$ and $2.25 \%$ if it is $300 \mathrm{~km}$. The used parameter is a generous value that does not underestimate the effect of investments. In any case, the results are robust against variations of this parameter at least in the range 15-30\%.

Figure 11 shows that there were practically no changes in the accessibility of the network until well into the nineteenth century, which means that there were no major changes in the transport costs of the different regions until the interconnection of the new roads made it possible to take full advantage of their possibilities. The development of the network of newly paved roads did not alter the advantage in transport costs that the center of the peninsula had shown since the sixteenth century. However, as it is often the case, there are two sides to every coin. While we have seen that the design had practically no impact at the level of the territory, it did have quite some impact at the level of cities. In fact, from regional competitiveness, the relative advantage within the region may be more important than the absolute advantage on a national scale. 
1750

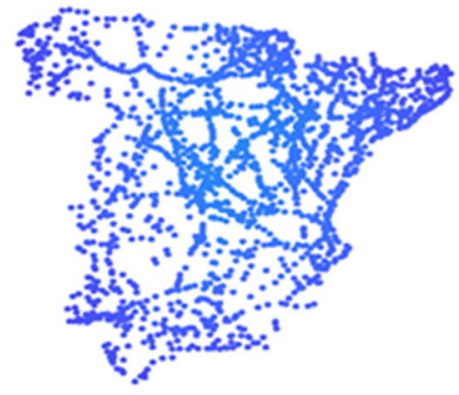

1820

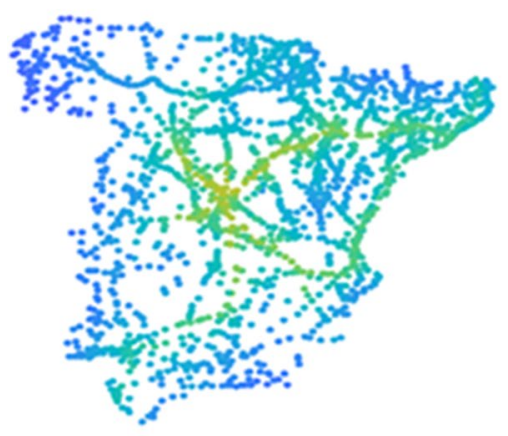

1780

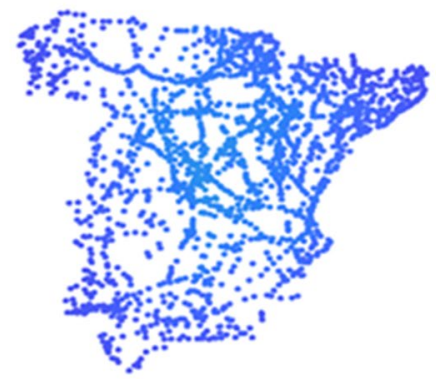

1850

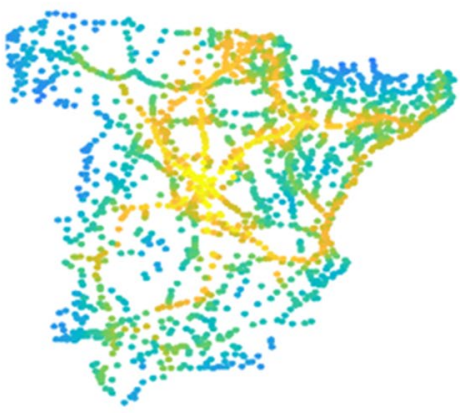

Fig. 11 Effect of network construction on accessibility. Accessibility is on absolute values, the same scale for all maps, and is calculated as described in the text. Each point is a town (node) that is part of the road network. The color indicates the total cost in terms of time to go to all the other villages. Blue is the lowest accessibility and yellow the highest

1700

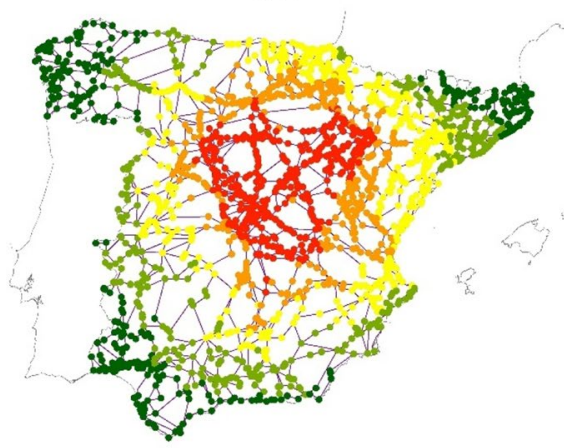

$\begin{array}{lll}\text { Closeness } & \text { Average } \\ \text { Very low } & \text { High } \\ \text { Low } & - \text { Very high }\end{array}$
1850

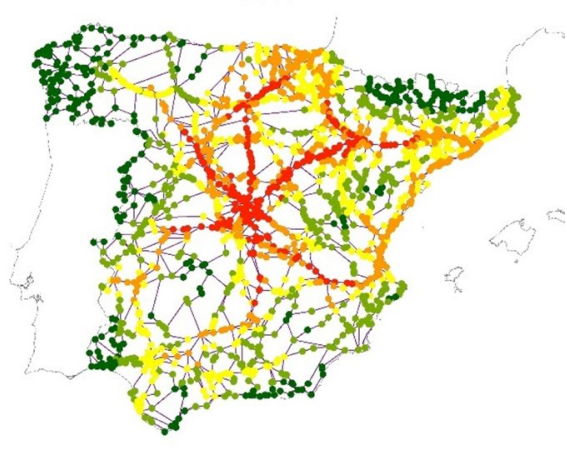

Fig. 12 Relative accessibility. The values reported in the maps are relative to the máximum value of the accessibility in each period. Values are color coded with dark green corresponding to very low values, green, low, yellow, average, orange, high and red, very high 
Table 2 Average accessibility by regions. Source: Own elaboration

\begin{tabular}{lccccccc}
\hline & 1700 & 1750 & 1780 & 1820 & 1850 & $\begin{array}{l}\text { Growth }\left(1750-\begin{array}{l}\text { Deviation } \\
1850)(\%)\end{array}\right. \\
\text { from nation } \\
(\%)\end{array}$ \\
\hline Andalusia & 0.45 & 0.45 & 0.48 & 1.16 & 1.48 & 227 & 13 \\
Aragon & 0.62 & 0.62 & 0.64 & 1.24 & 1.66 & 168 & -16 \\
New Castile & 0.63 & 0.64 & 0.69 & 1.38 & 1.92 & 201 & 0 \\
Old Castile & 0.66 & 0.66 & 0.71 & 1.30 & 1.97 & 197 & -2 \\
Catalonia & 0.47 & 0.47 & 0.49 & 1.28 & 1.63 & 247 & 23 \\
Galicia & 0.38 & 0.39 & 0.42 & 0.64 & 1.08 & 181 & -10 \\
Granada & 0.46 & 0.46 & 0.50 & 0.88 & 1.38 & 197 & -2 \\
Guipuzcoa* & 0.56 & 0.56 & 0.60 & 1.15 & 2.09 & 275 & 37 \\
La Rioja* & 0.63 & 0.63 & 0.66 & 1.04 & 1.96 & 211 & -26 \\
Asturias & 0.48 & 0.49 & 0.52 & 0.82 & 1.23 & 150 & -16 \\
León & 0.58 & 0.58 & 0.63 & 1.12 & 1.57 & 169 & -8 \\
Murcia & 0.51 & 0.51 & 0.56 & 1.11 & 1.46 & 186 & 7 \\
Navarre* & 0.59 & 0.59 & 0.62 & 1.10 & 1.87 & 215 & 4 \\
Valencia & 0.56 & 0.57 & 0.61 & 1.31 & 1.75 & 209 & 0 \\
Biscay* & 0.58 & 0.59 & 0.64 & 1.12 & 1.99 & 237 & 201 \\
SPAIN & 0.55 & 0.56 & 0.60 & 1.19 & 1.68 & 26 \\
CV & 0.14 & 0.14 & 0.14 & 0.17 & 0.18 & & \\
CV* & 0.16 & 0.15 & 0.15 & 0.19 & 0.17 & & \\
\hline
\end{tabular}

*The coefficient of variation $\mathrm{CV}^{*}$ has been calculated by taking the regions marked with an asterisk as a single region

Figure 12 shows the relative situation of the different towns and cities in relative terms, i.e., comparing them with the accessibility of the best-communicated nodes at any given time. In this way, it is possible to observe changes in the relative advantages of the territory. Before the construction of the newly paved roads, the advantages were basically positional — to be near the center of the territory-, but subsequently, they become dependent on the proximity to the improved network. As we can see, these variations are eminently local and should be attributed to specific cities and towns rather than to regions as a whole.

From a more quantitative perspective, variations in accessibility at the regional level can be estimated from weighted averages of the values of the constituent cities. However, the allocation of changes at the regional level could be biased, depending on whether the regions have changes in their territories during the period under consideration (Arbia 2001). Between 1700 and 1850, the territorial division of Spain underwent important modifications as witnessed by the political maps of the time (Sanson and Tavernier 1641; Sanson 1700; Homann 1750; López de Vargas y Machuca 1802; Martín de López 1834) so it is necessary to choose an invariant region of reference (Brown et al. 2005). This is an important issue as the results of the aggregations will depend on it. The use of the current territorial division in the analysis does not seem appropriate as both local identities and internal borders affecting trade in the eighteenth and first half of 
the nineteenth century do not exactly correspond to this division (Fig. 23). Additionally, the consideration of Madrid and its surroundings as a separate region from New Castile is a recent fact that does not occur until 1983. In view of this, the map we have selected as a regional reference for this work is that of Sanson (1700) as it refers to the beginning of the period analyzed and is the map that Martínez de Grimaldo (1720) used to establish his post routes. In order to assign the villages included in the analysis to the different regions, the map was rectified to adjust it to the spatial reality of the territory.

The data in Table 2 show how the general accessibility of the territory in 1850 was significantly higher than in 1700 . On a national level, the increase was close to $200 \%$. Regional differences range from around $25 \%$ to the average and do not show a clear geographical pattern.

The table shows that the two Castiles, Valencia and Granada see little change in their relative accessibility concerning the national average. Some coastal regions such as Catalonia, Andalusia, Biscay, or Guipuzcoa experience notable improvements while others such as Asturias, Galicia, or Murcia worsen. The rest of the inland regions, León, Navarra, and La Rioja have diverse behavior. The evolution of the variability of regional accessibility, measured by the coefficient of variation, shows a slight increase during the period studied, going from 0.14 to 0.18 . These results are highly influenced by what happens in the small regions of the north that appear marked in the table with an asterisk (Navarra, Guipuzcoa, Vizcaya, and La Rioja). Their small size means that the construction of new roads has a very strong effect on them as they affect a very high percentage of their territory. If we group them into a single region, the coefficient of variation becomes much more stable, going from 0.16 in 1700 to 0.17 in 1850 .

Our analysis leads us to conclude that the verification of hypothesis H2.A regarding whether 'The newly paved roads produced important changes on the mobility of the territory' is ambiguous. The roads significantly improved the accessibility of the whole country. They brought about a very important change in the mobility of the territory but with a fairly homogeneous spatial distribution not generating major alterations in the relative position of the different regions. There were no changes that turned well-communicated areas into bad areas or vice versa. Clearly, this must be understood in a relative sense since they all improve.

Instead, hypothesis H2.B about the positive effects of the construction of the newly paved roads were concentrated in a few regions, mainly Madrid and the coastal regions, introducing a comparative disadvantage for the inland regions, can be rejected for several reasons. Firstly, Madrid did not exist as a region until the end of the 20th century, and therefore, until the institution of the provinces in 1833, it can only be spoken of as a city within the region of New Castile. This, like Old Castile, hardly sees its relative position altered in terms of accessibility. It is true that the city of Madrid and some of the surrounding towns experienced a significant improvement in its communications, but other important cities in New Castile see as their relative position worsen in economic terms, as we will see later.

Secondly, and more importantly, the alleged comparative disadvantages faced by the center concerning the peripheral regions are not general-some regions 


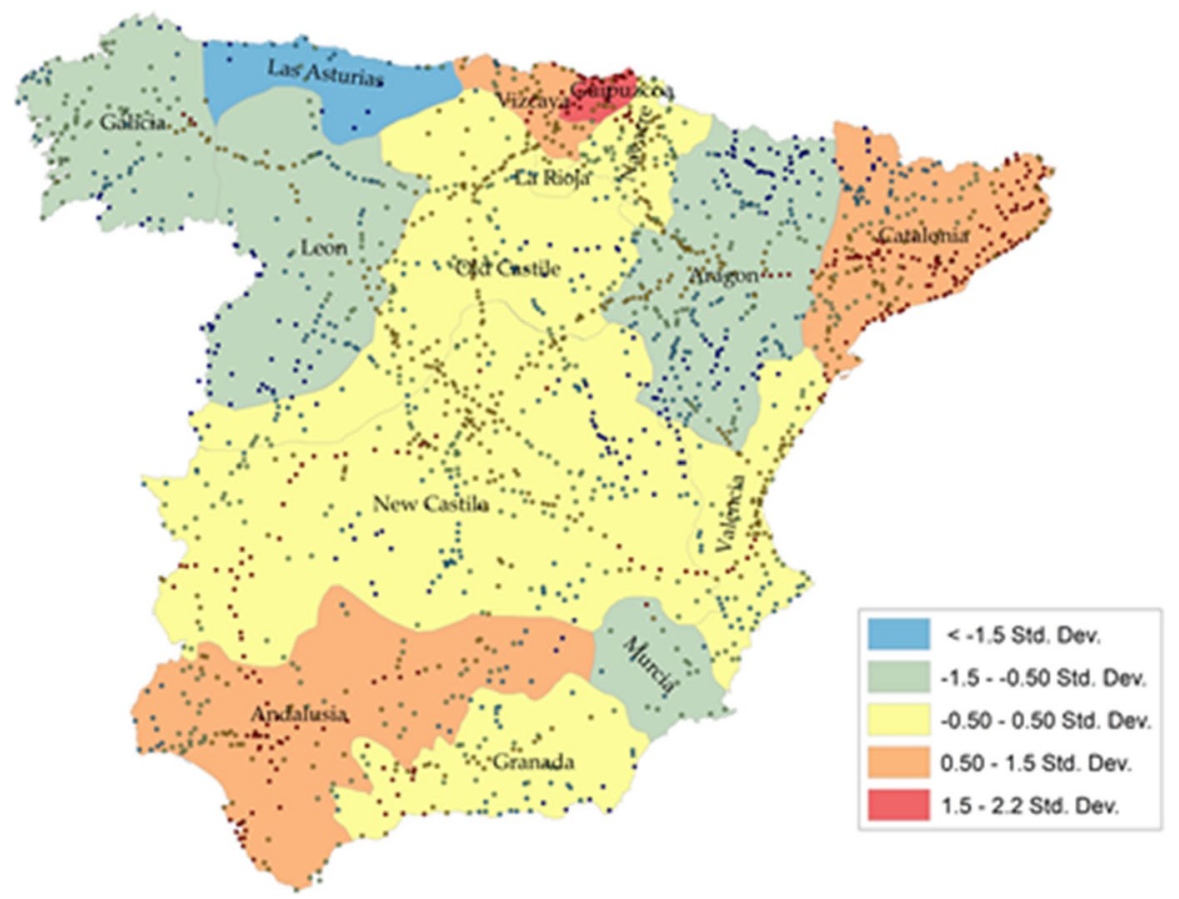

Fig. 13 Accessibility by regions and towns. Deviation from average growth (1750-1850). Color codes apply to both regions and cities. Numerical values for average accessibility are collected in Table 4 in the "Appendix"

are improving but others that are worsening — and on average they are practically non-existent.

To more clearly illustrate this point, Fig. 13 summarizes Table 2 classifying the regions according to the growth of their accessibility. Regions that show significantly below-average variations are represented in blue or pale green, while regions that exceed it are in red or orange, and those that have grown around the national average are colored in yellow.

The map shows how the peripheral regions do not improve their overall accessibility with respect to those in the center. Although there are regions that improve, there are also regions that get worse.

The markedly local origin of the variations in the accessibility of the territory can be noted by comparing the color of the regions with that of the populations that make them up. In many regions, some areas behave very differently from the regional average and are therefore not representative of them.

Let us now turn to the second indicator introduced above, betweenness centrality, which sheds much light on the impact of the design on cities and shows that the effects of infrastructure investments are not always positive. Intermediation or betweenness centrality is the number of optimal routes linking pairs of cities and towns that pass through a given town. This is a predictor of the likely traffic of people and goods passing through a village from other places (Barthelemy 2018). 


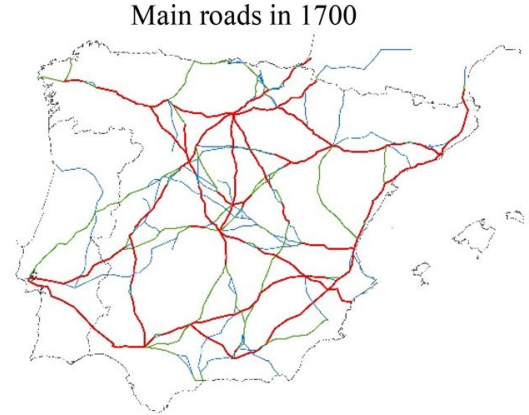

1750

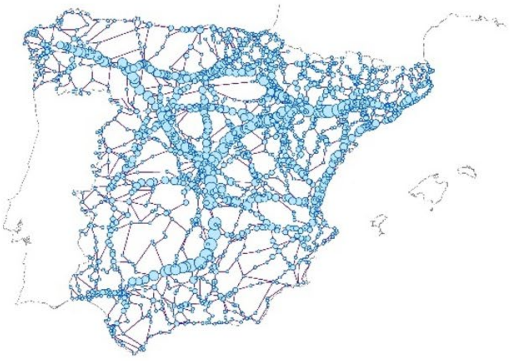

1820

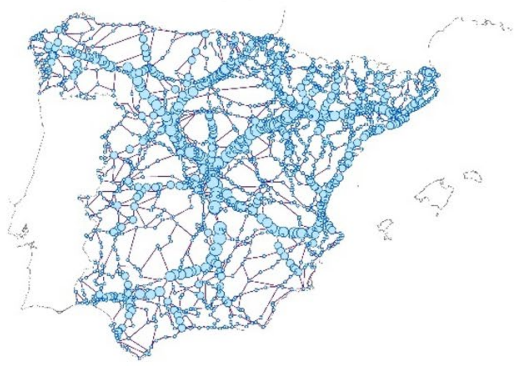

Spanish roads
Main roads
- Secondary roads
Other roads
1700

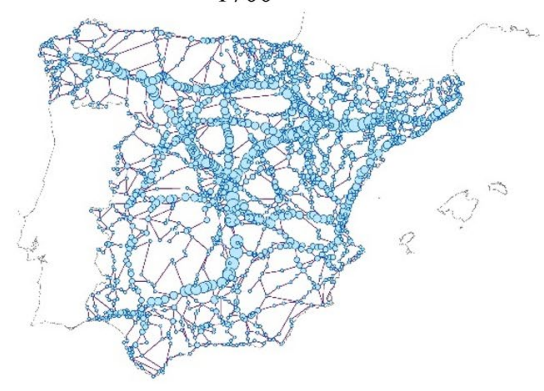

1780

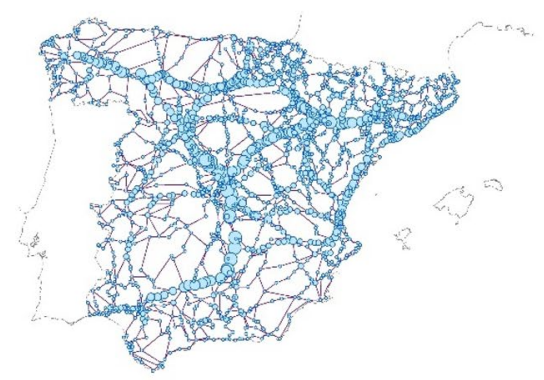

1850

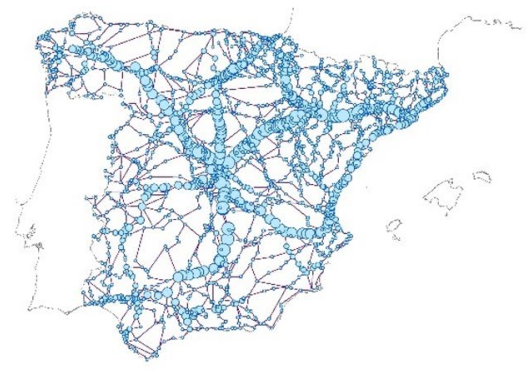

Betweenness centrality
$\circ$ Very low
0 Low
$\bigcirc$ Average
$\bigcirc$ High
$\bigcirc$ Very high

Fig. 14 Betweenness centrality (1700-1840). Top left map: in red, main roads; green, secondary roads, and blue, other roads. Elaborated by the authors from Anonymous and Pontón (1705), de B. F. and de Grieck (1704) and the map of Fer and Loon (1701). The rest of the maps combine the information on the development of the network from Madrazo Madrazo (1984a) with the authors' calculations of the centrality. The size of the circles represents the value of their centrality

As it is not a weighted measure, it does not allow us to determine exactly how much traffic passes through the village, but it does allow us to know how many different origins the travelers have if they follow optimal trajectories in their journeys. These data are important from an economic point of view as it is correlated 
Table 3 Concentration of betweenness centrality by regions (Gini index). Source: Own elaboration

\begin{tabular}{|c|c|c|c|c|c|c|}
\hline & 1700 & 1750 & 1780 & 1820 & 1850 & $\begin{array}{l}\text { Growth } \\
(1750-1850) \\
(\%)\end{array}$ \\
\hline Andalusia & 0.73 & 0.73 & 0.75 & 0.80 & 0.83 & 13.7 \\
\hline Aragon & 0.65 & 0.65 & 0.67 & 0.80 & 0.80 & 24.1 \\
\hline New Castile & 0.66 & 0.67 & 0.75 & 0.85 & 0.82 & 22.1 \\
\hline Old Castile & 0.54 & 0.55 & 0.62 & 0.81 & 0.77 & 40.0 \\
\hline Catalonia & 0.66 & 0.66 & 0.66 & 0.78 & 0.78 & 17.4 \\
\hline Galicia & 0.78 & 0.79 & 0.79 & 0.80 & 0.80 & 1.8 \\
\hline Granada & 0.54 & 0.54 & 0.54 & 0.64 & 0.76 & 41.9 \\
\hline Guipuzcoa* & 0.67 & 0.65 & 0.63 & 0.78 & 0.79 & 21.2 \\
\hline La Rioja* & 0.42 & 0.41 & 0.39 & 0.57 & 0.54 & 30.6 \\
\hline Las Asturias & 0.46 & 0.48 & 0.48 & 0.56 & 0.62 & 28.5 \\
\hline León & 0.55 & 0.56 & 0.57 & 0.72 & 0.79 & 40.9 \\
\hline Murcia & 0.34 & 0.34 & 0.34 & 0.58 & 0.61 & 76.6 \\
\hline Navarre* & 0.68 & 0.67 & 0.70 & 0.73 & 0.77 & 14.4 \\
\hline Valencia & 0.66 & 0.66 & 0.66 & 0.73 & 0.72 & 10.2 \\
\hline Vizcaya* & 0.66 & 0.67 & 0.68 & 0.80 & 0.80 & 20.4 \\
\hline SPAIN & 0.67 & 0.68 & 0.71 & 0.82 & 0.81 & 20.1 \\
\hline $\mathrm{CV}$ & 0.20 & 0.19 & 0.20 & 0.13 & 0.11 & \\
\hline $\mathrm{CV}^{*}$ & 0.19 & 0.19 & 0.20 & 0.12 & 0.09 & \\
\hline
\end{tabular}

*The coefficient of variation $\mathrm{CV}^{*}$ has been calculated by taking the regions marked with an asterisk as a single region

both with the arrival of travelers and with the variety of products traded in the town and, therefore, with the breadth of its market.

Although every time a road is improved it increases, to a greater or lesser extent, the accessibility of all the nodes of the network, the induced change in terms of betweenness centrality is a zero-sum game that involves improvements for some nodes and worsening for others. Changes in traffic flow caused by investments improve the situation of certain nuclei to the extent that they receive more travelers and goods because they are located on a greater number of optimal routes. On the contrary, the nuclei that reduce their betweenness centrality lost economic relevance with the fall in traffic flows. To study this issue, and to have a reference of which were the most important roads at the beginning of the eighteenth century, the information of Anonymous and Pontón (1705), de B. F. and de Grieck (1704), and the map of Fer et al. (1701) were integrated similarly as it was done to rebuild the sixteenth- and seventeenth-century networks. As expected, both maps show great similarities. Only the best connectivity with Portugal in the southwestern area and the consolidation of the north transversal axis Santiago-Barcelona stand out as differences.

The analysis of the changes in betweenness centrality confirms that already in 1700 the structure of potential traffic in the network was radial and with the center in Madrid (cf. Fig. 14). 
The six main axes were complemented by eight others: two of them running north-south, the Silver Way and the one that follows the Mediterranean coast from Barcelona to Alicante; another two, east-west, the Duero axis and the LeónZaragoza axis; and four transversal ones, Burgos-Cáceres, Burgos-Cuenca-El Campillo, Zaragoza-Teruel-Sagunto and Albacete-Ciudad Real. These fourteen axes totaled around $7000 \mathrm{~km}$, of which the six radials accounted for approximately half. The strong correlation between the classification of roads obtained from historical sources for 1700 and the centrality map of intermediation built from an unweighted road network is a strong support for the above hypothesis that in the eighteenth century the differences between roads were not due to differences in quality but to differences in traffic. Starting from this situation in 1700, the development of infrastructures in the period 1700-1850 meant greater commercial activity in the cities of the radial axes and, consequently, a decline in those located on the complementary axes, except those of the Mediterranean, which maintained their potential traffic practically unchanged, and those of the Santiago-Barcelona axis, except in the central section León-Logroño. The key point here is that these changes happen at the territorial level too, and nodes that were very important within a region also lose power or relevance versus other nodes that are becoming local hubs.

Table 3 shows the evolution of the concentration of betweenness centrality by regions. Infrastructure investments meant that potential traffic was increasingly concentrated in the small number of cities along which the new roads ran. At the national level, the new roads led to an increment of the concentration of betweenness centrality by $20 \%$, from 0.67 to 0.81 . The reduction in the coefficients of variation of the Gini index indicates a tendency to homogenize the concentration of centrality among the region, suggesting that changes were primarily at the city level rather than at the regional level.

Indeed, the distinct effect of the development of the road network had on different towns is depicted in Fig. 15. The plots show the change of accessibility and betweenness centrality for some of the main cities in the period 1700-1850. The upper panel shows the evolution of accessibility and betweenness centrality for the main cities as improvements are made to the road network. It is interesting to see how accessibility always improves but betweenness centrality can be suddenly reduced as a result of changes in traffic flows. The central panel in Fig. 15 summarizes the previous plot and demonstrates that, in relative terms, the city that benefited the most from the work on the roads in this period was Barcelona followed at a certain distance by Madrid, Granada, and Cordoba.

Instead, for the rest of the cities, betweenness centrality remained basically constant or even reduced, the improvements being restricted to their accessibility. Additional information is provided in the lower panel of Fig. 15, where towns connected through radial roads are depicted as green symbols, and otherwise, they are shown in blue (Madrid is highlighted in red), with symbol size indicating the distance to Madrid. It can be seen from this plot that towns that profited most from the road-building activity in the period are those that are far from the center, and of course those lying along radial roads. The benefit comes mostly from the increase in accessibility, which means their distance to the towns in the network decreases in general, rather than from betweenness centrality, as being in the periphery makes 


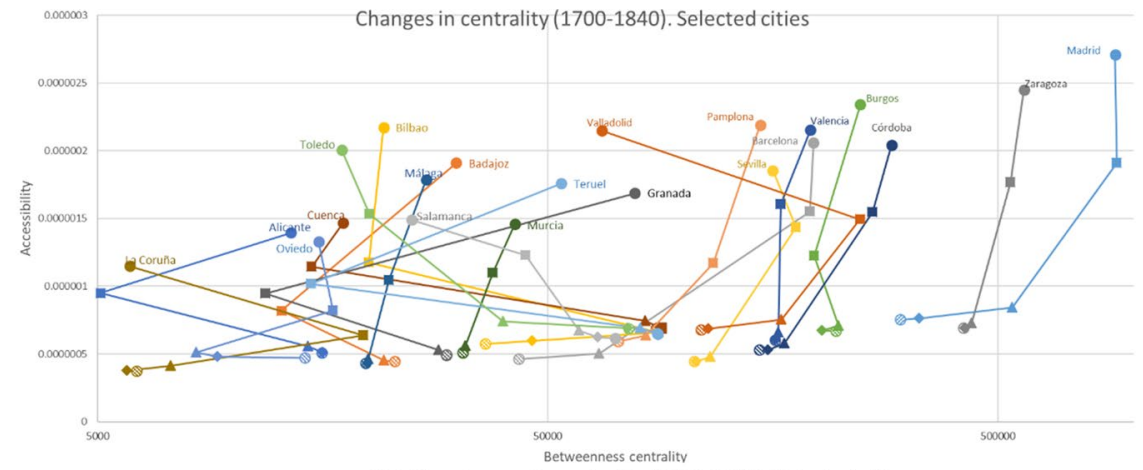

Relative changes in centrality (1700-1840). Selected cities

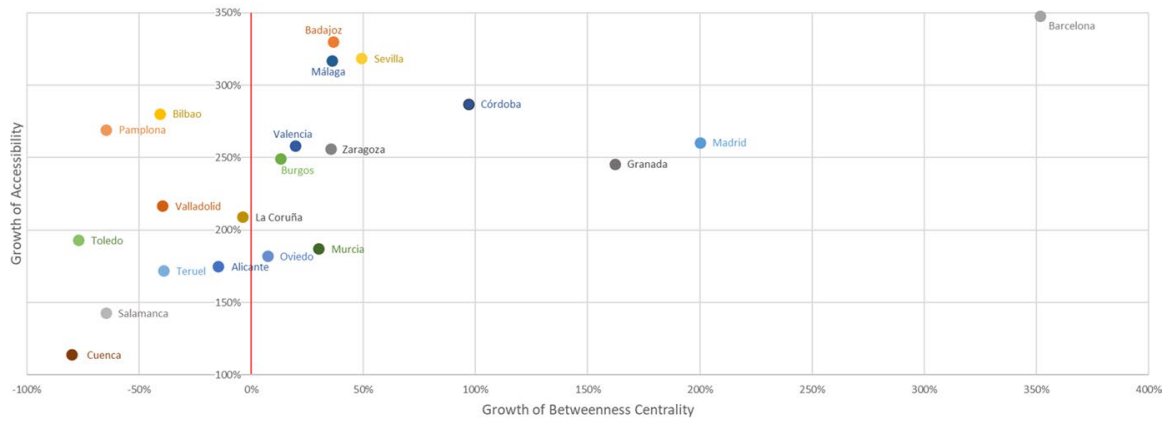

Relative changes in centrality (1700-1840). Selected cities

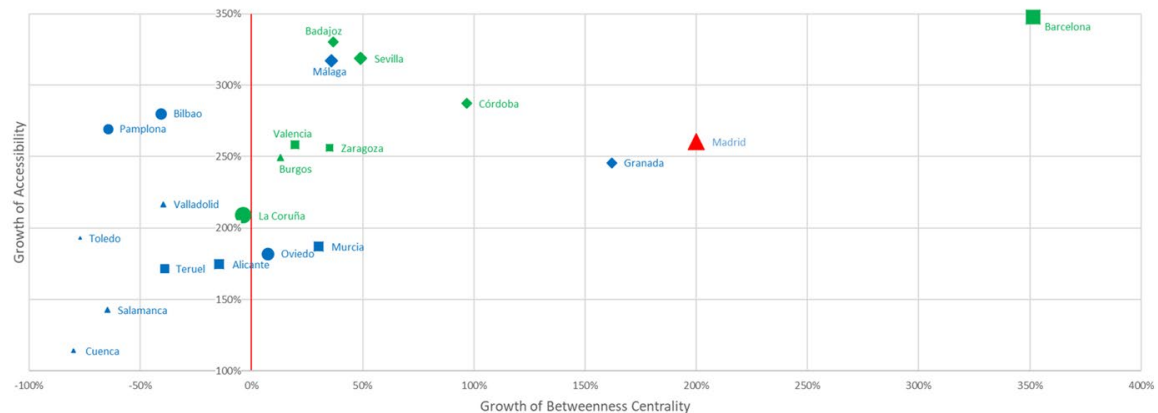

Fig. 15 Improvements to the road network and change in accessibility and betweenness centrality (17001850). Upper panel, time evolution. Circles filled with stripes represent the starting point in 1700, diamonds correspond to the situation after the first investments in 1750 , triangles to 1780 , squares to 1820 , and circles to 1850. Colors correspond to different towns as indicated in the plot. Middle panel, relative changes in centralities in the period considered. The color code is the same as in the upper panel. Lower panel, same as the previous panel but towns are shown in green if they are included in radial roads and in blue otherwise (Madrid is shown in red as the center). The shape of symbols indicates broad geographical locations: triangles in the center of the peninsula, roughly Castilla, squares in the East (Crown of Aragón and Murcia), diamonds for the South (Andalucia and Extremadura), and circles for the North (Galicia, Asturias, País Vasco y Navarra). The size of the symbol represents the distance to Madrid

it very difficult for them to be in many shortest paths. Again, the case of Barcelona is special in this respect, with a large increase in betweenness centrality due 
$1700-1750$

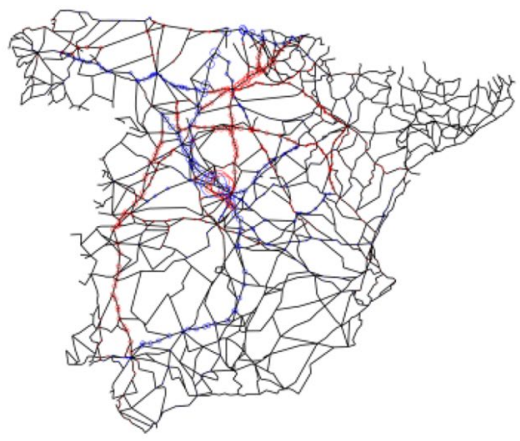

$1780-1820$

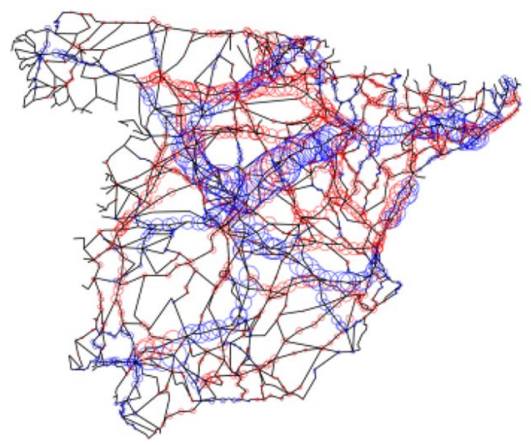

$1750-1780$

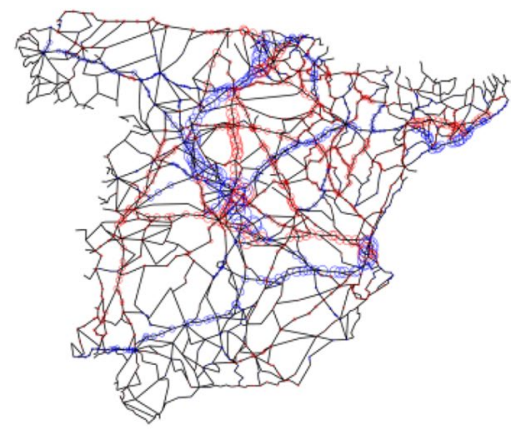

$1820-1850$

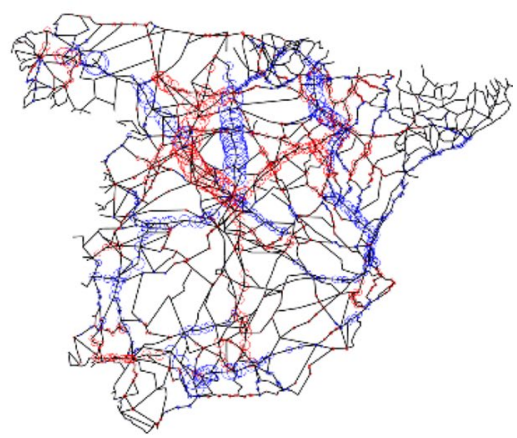

Fig. 16 Changes in the betweenness centrality due to new roads. Nodes of the network are shown as circles, while colors indicate a change in intermediation, with blue (red) nodes having experienced an increase (decrease) of intermediation. The size of the circles represents the size of the change

to the improvements along the Mediterranean coast as well as in the connection with Zaragoza, which made it more advantageous to travel from the East to Madrid through Barcelona and Zaragoza.

As noted above, a very important point to make in connection with this analysis is that variations in betweenness centrality are not always positive, as shown by the upper panel of Fig. 14. Indeed, they can even be initially of a sign and change when a new development of the network takes place. For instance, Teruel saw how the new roads reduced the potential traffic that passed through it until 1820 when the initiation of the Zaragoza-Sagunto axis allowed it to recover a good part of the lost centrality. The opposite is the case of Valladolid. Until 1820 , its position was slightly improved, but the completion of the radial connections with Burgos and Benavente meant a drastic reduction in its position advantages. Even more dramatic are the cases of Toledo and Cuenca, clear examples of how infrastructure development can lead cities to logistical irrelevance. Toledo had already lost a good part of its position advantages with the opening of the direct road to the south by Aranjuez, but the development of the road to Andalusia meant a reduction of its centrality as it was built. The closure of the 


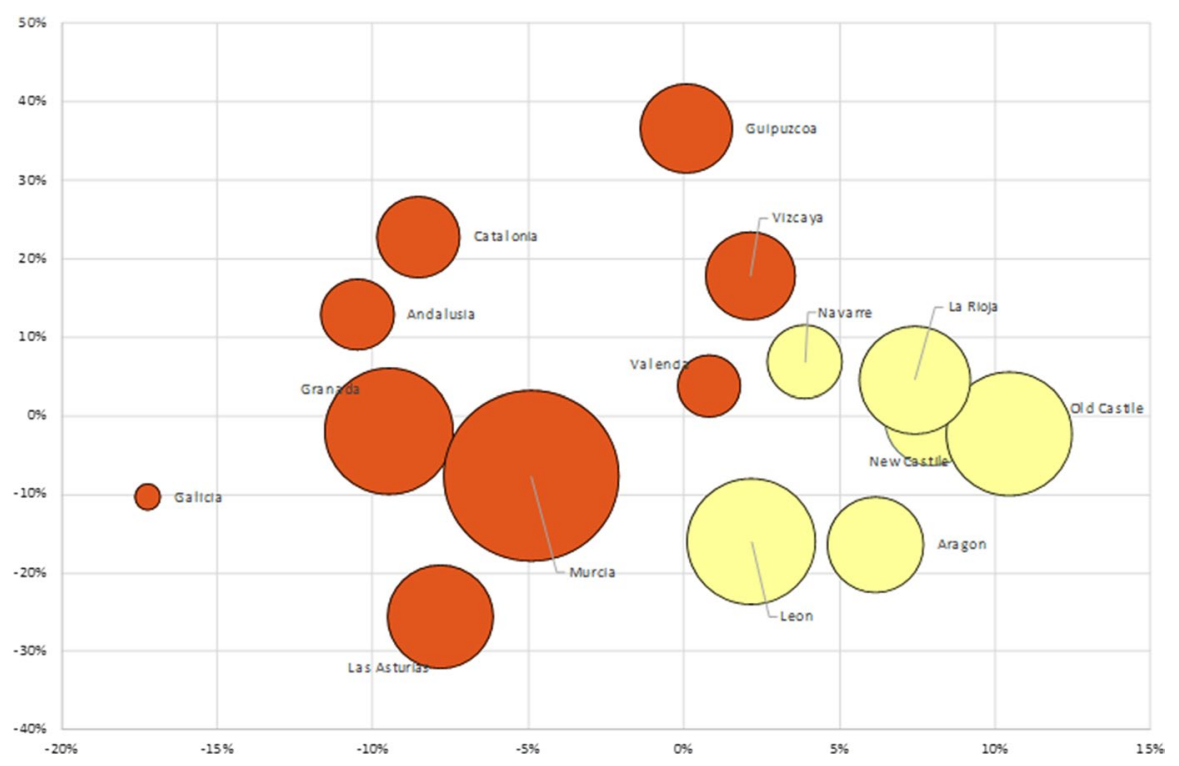

Fig. 17 Accessibility. $\beta$-convergence between regions (1750-1850)

Valencia road by the Utiel-Requena route in 1820 meant a serious deterioration of Cuenca`s centrality which had already been worsening since the beginning of the development of the network. The construction in 1850 of a large part of the connection with the Barcelona road only meant a reduced recovery of potential traffic, as it only managed to redirect the traffic generated around Guadalajara. This is an aspect that is scarcely considered by decision-makers and by the citizenship at large, not only in the eighteenth and nineteenth centuries but today: While road improvement always leads to an increase in accessibility (travel times can only decrease from road improvements), its effect on betweenness centrality and hence on the relevance of a town for many important aspects, e.g., as a trade hub, is highly non-trivial and can be positive or negative. The greater relevance of betweenness centrality versus accessibility when taking advantage of the new roads is highlighted by Ghani et al. (2016) for India. Although the new roads improve accessibility in a fairly homogeneous way in the territory, most of the benefits are obtained by the towns located on the road.

This is further shown in Fig. 16, which shows a general view of how the gradual development of the network altered betweenness centrality of the villages as the different phases took place. These results are consistent with those recently obtained by other authors (Berger and Enflo 2017) in the sense that transport infrastructure development does not necessarily generate territorial convergence and that transitory shocks generate path dependence in the location of economic activity (Bleakley and Lin 2012; Jedwab and Moradi 2016; Jedwab et al. 2017).

Finally, let us consider hypothesis H2.C, namely that 'effects were mainly at the level of cities, not so much of region.' In light of our analysis of centralities, we have to conclude that hypothesis H2.C is confirmed. Although the improvements in terms 
of accessibility were spread out territorially quite homogeneously, the improvements in the road network significantly modified the trade flows which made the cities and towns along the roads gain importance to the detriment of other cities. This phenomenon is particularly intense at the beginning of the development of the network when the number of improved routes is low because it generates a more intense concentration of traffic. As the concentration increases, the advantages of these cities are reduced from a logistic point of view but can be maintained thanks to the path dependence. Temporary advantages can lead to cities developing permanent advantages such as population size, the establishment of fairs, or simply the development of travel habits that keep traffic on the same routes despite the existence of new alternatives. This means that it may be appropriate from an economic policy point of view to alter the optimum sequence in the construction of the network by prioritizing less efficient sections if a territorial rebalancing is to be achieved (Pablo-Martí and Sánchez 2017).

Figure 17 summarizes the effects of road network improvements on inequalities at the regional level using a $\beta$-convergence analysis (Barro and Sala-i-Martin 1992). In brief, $\beta$-convergence is a procedure that allows quantifying the degree of convergence in accessibility. The horizontal axis shows the regional accessibility in 1750 as a deviation from the national average and the ordinate axis shows the average growth of accessibility in the period 1750-1850, also as a deviation from the national average. The low value of the regression slope $(0.08)$ and its scarce explanatory power $(R 2=0.0016)$ suggest that the construction of the network did not imply important variations in the interregional differences. The potential balancing effect of lower accessibility growth in inland regions (in yellow in the graph) was compensated by very different behaviors among coastal regions. Besides, the size of the points indicates the variation in intraregional concentration measured by the Gini index of the intermediation centrality.

\subsection{An efficient design}

Last, but not least, we consider whether the radial network design that was chosen in the second half of the eighteenth century, and especially in the first half of the nineteenth century, was based on economic rationality or whether, on the contrary, it only intended to achieve certain political and administrative objectives. To this end, the empirical network will be compared with the one that would have arisen through decentralized decision-making processes that sought greater efficiency in the transport system.

\subsubsection{An agent-based simulation model for the design of optimal transport networks}

It is not appropriate to speak of a unique criterion of optimality for transport networks, but of many, since the definition of optimality depends both on the objectives set and on the decision-makers. Thus, the final assessment will be determined by the decision-making process and, in general, by the system of aggregation of 
preferences used. It is therefore not possible to determine whether the transport system with its center in Madrid, which began in the eighteenth century, is the optimal one: The proper way to frame this question is to ask whether it is among the most reasonable choices for a wide range of assumptions. As the choice of the criteria to optimize and the decision-making system can be very different and influenced by many subjective judgments, we decided to develop a general model that makes it possible to evaluate different options for transport networks using a counterfactual analysis to obtain valid conclusions in the widest possible range of situations. This research aligns with the rapidly growing application of counterfactual analysis using computer simulations in the study of transport networks, even if as of today it is still incipient. Such approaches have been the subject of two major criticisms in the past, but are no longer valid to a large extent (Casson 2009) as we discuss in what follows.

It has often been argued that computer simulations cannot be detailed enough for the counterfactual to allow a reliable comparison with reality. However, the current availability of information sources and calculation capacity makes it fully possible to carry out this task. Projects such as AIMSUM (Barceló et al. 2005) or MATSIM (Horni et al. 2016) show how current simulation systems allow a much better approach to reality than with traditional methods. On the other hand, it has been pointed out that simulation does not allow us to get close enough to reality since it ignores important physical or technological limitations that can seriously alter the analysis. This criticism does not take into account one of the most positive characteristics of this approach and that is that simulation, unlike other methodologies, allows for the incorporation of new restrictions as they become necessary without having to substantially alter the conceptual framework. Basically, those two objections are largely superseded by models having enough granularity and versatility that can be run efficiently on the big computing infrastructures available today. This makes computer simulation one of the most appropriate ways to analyze the formation and evolution of transport networks, especially in environments with scarce information such as historical analysis. ${ }^{8}$

An alternative approach could be the use of bio-inspired techniques, that in recent years have experienced a notable development. Thus, Nakagaki et al. (2001) showed the computation capabilities of mud mold-physarum polycephalum to solve problems of determining optimal paths. The results obtained showed a structure comparable to the real one in terms of efficiency, fault tolerance, and transport cost. This methodology has been widely applied for the analysis of transport networks and lately also in the historical analysis (Strano et al. 2012; Adamatzky 2012; Evangelidis et al. 2015). The evolution of the Spanish road network has also been analyzed by mud mold (Adamatzky and Alonso-Sanz 2011). However, this methodology shows serious problems for its direct application in practical cases that go beyond mere conceptual frameworks given the high sensitivity of the results to variations in the diffusion of chemo-attractors that determine the development of plasmodium.

\footnotetext{
8 The software developed to answer the questions raised in this work has been developed in MATLAB and is available for download on the project website.
} 

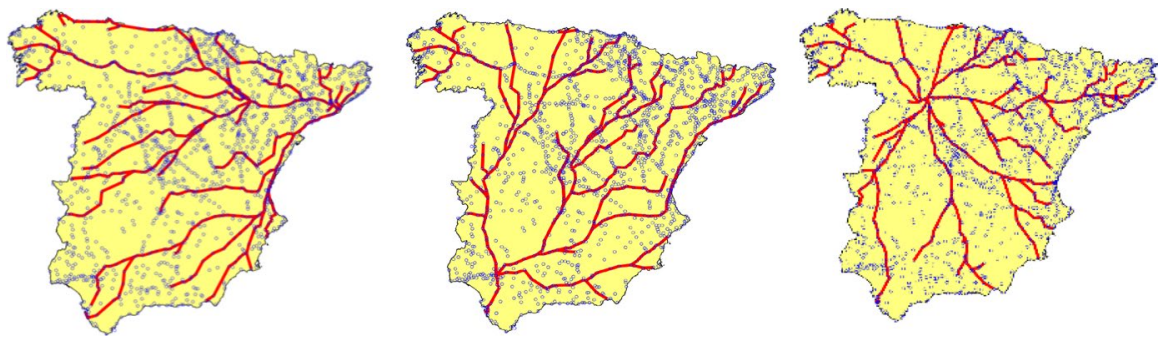

Fig. 18 Optimal networks depend on the city they refer to. Calculation of the optimal networks for three cities: Barcelona, Seville and Valladolid using the procedure described in the text, based on the Dijkstra (1959) algorithm

To avoid these limitations, biosimulation is being replaced by computer simulation using cellular automata (Tsompanas et al. 2016). ${ }^{9}$

\subsubsection{Criteria to decide on improvements}

Once we chose to work using computer simulations, the next step is to establish reasonable criteria for the development of the road network and to observe whether the results arising from our approach under each of the criteria differ significantly from those observed in reality. For this purpose, we rely on an optimal transport network generation model developed by Pablo-Martí and Sánchez (2017), which allows the selection of the sections to be improved from a preexisting network to achieve maximum benefit from a global perspective based on the individual preferences of each of the agents, the optimization criteria, and the voting system.

The model starts from the situation of the road at a given time and builds the improved road by choosing one segment at a time according to the different criteria. For the application of interest here, namely the optimality of the improvements of the Spanish road network during the eighteenth and nineteenth centuries, we resort as the preexisting network to one built based on information from the map of Valk (1704) and the itineraries of Anonymous and Pontón (1705) and de B. F. and de Grieck (1704), as mentioned above, made up of 2343 independent road sections. Although the model allows any type of decision-making agent to be established, in this case, the agents are the 1815 towns considered, i.e., the nodes of the network. The weights of the influence of each of the nodes in the selection processes were made based on transport costs and population. ${ }^{10}$ For the largest towns, $12.5 \%$ of the total, the demographic information provided by Correas (1988) was used as a proxy for this variable. For all other cases, class markers were used according to the categorization used by Valk (1704) in its map.

\footnotetext{
9 Other approaches such as those based on route optimization on cost maps (Voigtlaender and Voth 2019) or network generation (Faber 2014; Prignano et al. 2019) have the disadvantage of only taking into account local optimization, so they have difficulty in assessing whether intermediate nodes should be incorporated even if they increase the length of the route or consider weightings for the nodes.

${ }^{10}$ Except in the case of the unweighted model that only transport costs were used.
} 
The calculation of the optimal routes is done by applying the Dijkstra algorithm (Dijkstra 1959). Each node explores the different alternative routes that link it with the other nodes and selects the itineraries that imply a lower transport cost. By way of example, the network that three cities would choose if the decision was made for their benefit alone is presented in Fig. 18. Note how tree structures are generated in all cases, distributed radially, and starting from each of the nodes. However, these optimal structures have few sections in common. This is why the construction of a reasonable network that aggregates the preferences of all the nodes is done below through a voting system using different viewpoints.

In what follows, and for the sake of simplicity, the total cost of transport is expressed in the model in terms of time, although it would be possible to use other criteria such as monetary ones. About traffic, an estimate is made using gravitational models that take into account both the size of the pair of nodes considered and the squared distance that separates them. Based on this information, in every period each node chooses the section that would be most convenient for it to be improved from its accessibility to the rest of the nodes and the section that would produce the largest increase in its traffic. To this end, each node calculates the variation in total transport time and traffic that would result from the improvement of each of the sections in which it has not yet occurred, choosing, in the first case, the one that minimizes it the most and, in the second case, the one that maximizes it the most. Thus, agents seek to maximize the benefits derived from the improvement of the network without taking into account the conduct of the rest of the agents, which is why strategic or collusive behavior is not considered in the model.

The generation of the improved network is done through the following iterative process. First, each node distributes its vote among all the sections in proportion to the benefit it brings as discussed above. Next, the stretch that has obtained the most support is selected and improved. Improving a section in the model means that the travel time between the two towns on the section is reduced by 25 percent as done in Sect. 4.2. Once this has been done, the agents vote again among the rest of the sections, selecting successively the sections to improve until there are no more or the established budget is exhausted. This being a sequential process, the first investments made affect subsequent decisions in a clear example of path dependence. We want to emphasize that this does not necessarily mean that the process is not optimal because a one-time design would hardly be carried out simultaneously so different sections could be disconnected and the advantages of the network could be diminished. Even if the result was optimal it would be greatly affected by variations in the budget or changes in the project. Whether the planned network was not completed for some reason or, on the contrary, had to be extended, a suboptimal network would be obtained. The sequential approach ensures that the design is optimal for the level of development and investment achieved.

To assess the optimality of the network having in mind various economic objectives, three voting systems were established:

A. Equal voting power. All towns have the same voting power, and their objective is simply to reduce the travel time to the rest of the towns. For this purpose, each town calculates the travel time to each of the other villages for each of the net- 


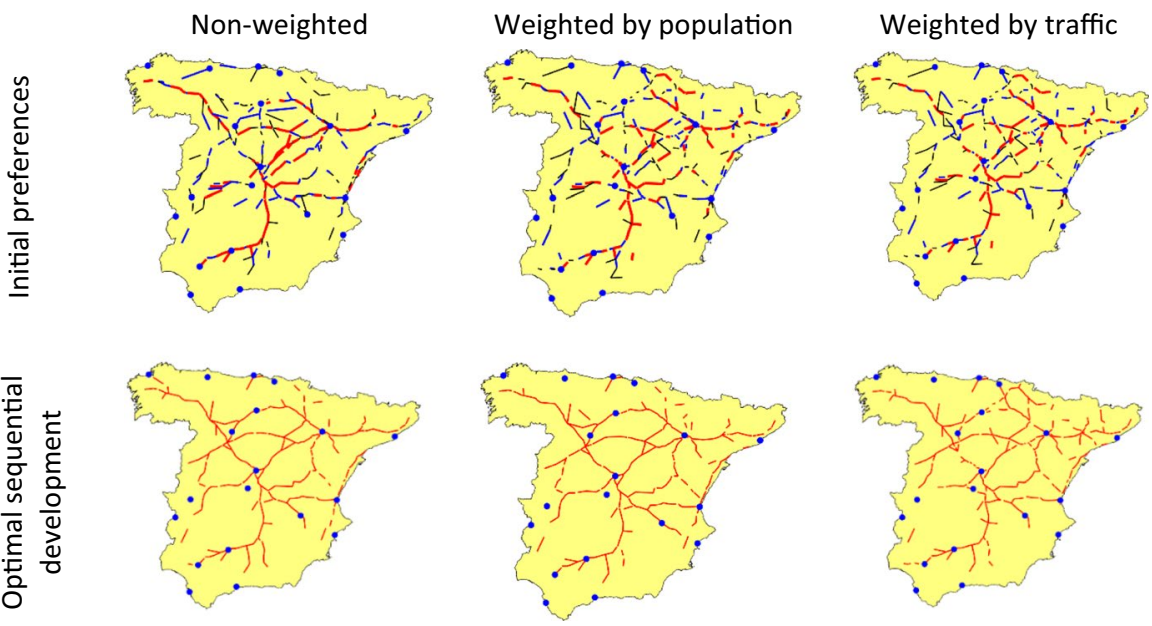

Fig. 19 Optimal transport networks for the eighteenth century according to the three voting procedures discussed in the text. Initial preferences (above) and optimal sequential development (below). The maps at the top show the initial preferences of the populations according to the three criteria. The 300 sections with the highest preference are marked, in order of importance, in red, blue, and finally in black. The final result is quite representative of the initial preference structure but shows a higher level of coordination

work improvement alternatives. Once the advantages have been estimated, they distribute their votes among the different alternatives in proportion to the expected benefits. Unlike other works (Adamatzky and Alonso-Sanz 2011; Equipo Urbano 1972; Vanoutrive et al. 2018), this procedure involves an intense effort of calculation as each town must estimate the optimal routes and consequent transport costs or gravitational models for each of the other 1814 towns, for each of the 2343 sections that can be improved, for each of the 300 investments and the three voting systems. This means a total of $1.1 \times 10^{12}$ optimal routes, transport cost calculations, and gravitational models.

This eminently territorial selection criterion would lead to an optimal network for the transmission of news in a country where there is no telecommunications infrastructure. However, it would be inappropriate if the objective were to promote commercial activity between large population centers, as this criterion does not take into account the importance of traffic between nodes. It would be ideal, for example, to define the post roads.

B. Population-weighted power. In this case, towns and cities also try to reduce travel time to the rest of the localities. The voting process is similar to the previous case but the voting power of each town is weighted by their population. This criterion has smaller economic applicability than the other two insofar commercial activity is being considered, but only partially because the negative effect of distance between towns is not included. This is more often the case in areas such as cultural dissemination rather than trade and transport. The distribution by place of publication of the books in a library, for example, depends more on the economic and cultural importance of the cities than on their distance. 

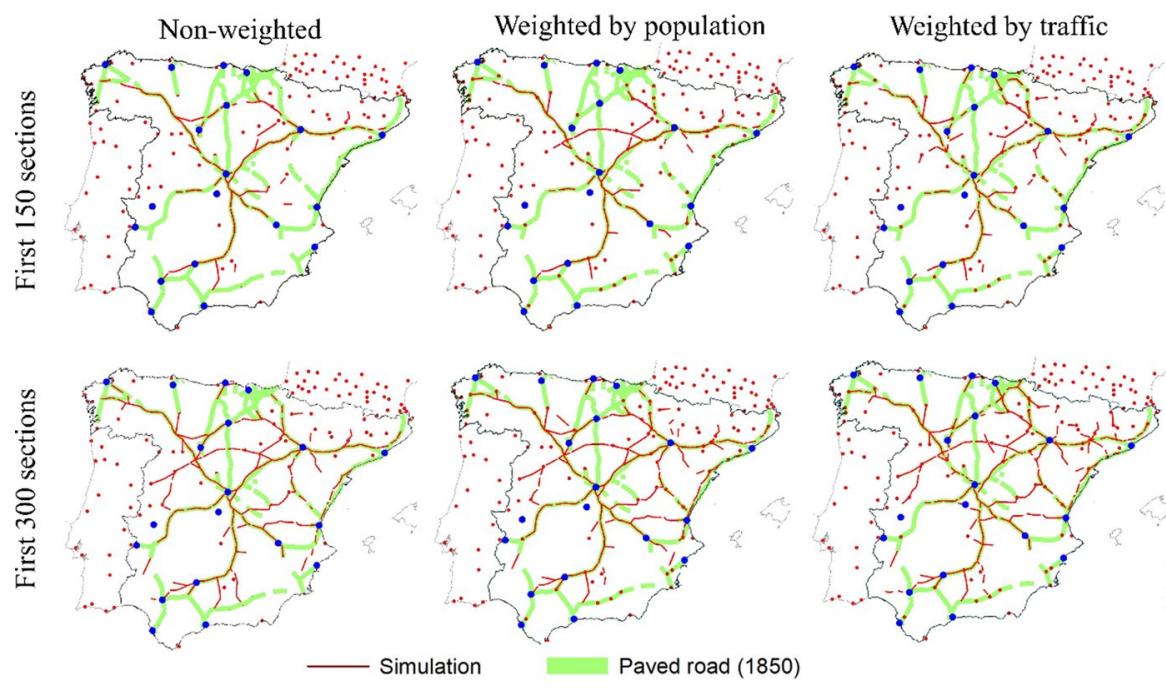

Fig. 20 Comparison of the simulated paved road subnetwork with the one built for 1850. Red, simulation results; green, paved road circa 1850

C. Traffic-oriented voting. Towns try to maximize the traffic of goods reducing the cost of transport on the most used road sections. It would be the most appropriate system to capture the economic aspects of the network. Each town estimates for each road section the effect it would have on its trade with the rest of the towns whether it would be improved by using gravitational models. It is clear, once again, that the structures rationally optimal from an economic point of view are multiple (Kolars and Malin 1970; Rietveld and van Nierop 1995) and depend on the objectives set by the intervening decision-makers and the system chosen to reach consensus. Figure 19 shows the results obtained using the three criteria indicated above for 300 improved sections, representing $12.8 \%$ of the initial network. For a video illustrating the process of network formation, cf. https://vimeo .com/362753400/d23a0dcabb. The three simulations offer very similar results, indicating that the network obtained is fairly robust with respect to variations in decision criteria. It is therefore an adequate network from the point of view of people's mobility, news transmission and freight traffic.

The great similarity of the networks generated by simulation with the network at the beginning of the eighteenth century can be assessed by comparing both networks, as shown in Fig. 20. This also allows us to conclude that both hypothesis H3.A, 'whether the radial network designed by the Bourbon monarchs of the second half of the eighteenth century can emerge from a distributed decision-making process in which all the populations of the nation are taken into account in a non-discriminatory manner,' and H3.B, 'it is determined whether the military, political, or administrative criteria outlined by various authors are compatible with maximizing commercial traffic' are correct. 
These results provide evidence that the radial design followed by the Spanish road system during the Habsburg dynasty, and which was later used in the eighteenth century to establish the post roads and the Bourbon paved roads, was considerably efficient, despite having emerged in an uncoordinated and spontaneously way. The main difference observed between the reality and the simulations is the lack of direct connection with France by Irun. This postal route, the Mala, does not appear in the simulation because, as discussed above, the model applied only considers national connections. The port and border effects were not included in the weightings of the peripheral populations because reliable information on the magnitude of the effects was not available. This design of the transport network has remained largely valid, as evidenced by its subsequent use in both the deployment of the rail network in the nineteenth century and the road and high-speed train networks of the twentieth century.

Concerning the questions raised in the introduction about the nature of the dynamic process, we can conclude that the development of the network coincides to a large extent with the country's territorial constraints. That is, it can largely be explained by the initial parameters. Insofar as the construction criterion was eminently pragmatic, the road sections were improved, showing 10 greater use in an endogenous and non-intervened manner. However, the development of the network in response to these determining factors was not the only alternative. Another network design could have been chosen or followed a different rhythm or sequencing which would have led to different results, especially for the relative importance of cities and transport flows, so it can be considered a genuine path-dependent process.

\section{Conclusions}

In this paper, we have presented a combined methodology incorporating GIS techniques, network science, and agent-based modeling, exemplified through its application to understanding the evolution of the road network in Spain in the period 1700-1850. As a first result, our thorough review of the available literature taking advantage of the availability of digitalized maps from the period has led to a description of the roads in that period with unprecedented detail and accuracy, particularly of the situation at the beginning of the eighteenth century (Fig. 6 above). Building on that data collection and processing, we have critically assessed several claims that have been widely discussed in the literature without reaching a definitive conclusion. In this section, we summarize our conclusions regarding those claims and close with a brief discussion of other possible applications of our methodology.

Firstly, it has been claimed by many historians and politicians that the accession of the Bourbons to the Spanish throne was accompanied by the implementation of a radial design of the road network superseding the less centralist one existing at the beginning of the eighteenth century. Instead, our analysis does not support this claim, because as we have seen the successive Bourbon kings and officials largely adopted the sixteenth-century design they found in 1700, and we have demonstrated that this design had already a marked radial character. 
Secondly, another commonly held view assumes that the new monarchy introduced changes in the road network that altered the development of the different territories of Spain, promoting the capital and forgetting peripheral regions. We find that the Bourbon infrastructure policy neither generated significant changes in the transport network nor induced major alterations in territorial balance or privileged the region where the capital was located. During the eighteenth century improvements in the network were sparse and unconnected, so the effects were mainly local. In the first half of the nineteenth century, construction accelerated, almost simultaneously connecting many of the previously unconnected sections. Therefore, the potential impulse to the capital due to the implementation of an improved radial structure was accompanied by the construction of relevant transverse connections, resulting in a more or less homogeneous improvement of conditions and commerce along the whole of Spain.

Thirdly, building on a network description of the Spanish roads as we have mapped them, and using agent-based simulations with different criteria to choose which parts of the network should be improved and when, we have also shown that the design followed both in the network of post roads and in the newly paved roads was carried out with reasonable economic criteria, both from the transport of mail and the mobility of people and the transport of goods. Indeed, a similar structure for the roads arises from the three largely different criteria we have considered as possible counterfactuals, indicating that the actual road network existing by the end of the period considered is compatible with many objective economic optimization criteria.

In closing, we want to stress that the increasing availability of historic material in digital form, and particularly of maps amenable to GIS analysis, makes our approach widely applicable in the study of socioeconomic historic developments. As we have seen, having an in-depth knowledge of the evolution of the process of interest allows establishing to which degree it is path-dependent, as well as the main effects of the historical sequence of interventions. Thus, rigorous, evidence-based approaches involving a detailed review of the new available primary sources, including the cartographical ones, can shed light on the origins of many critical infrastructures that cannot be understood without taking into account their path dependence evolution. A network science analysis based on centralities points to different contexts, in a multilevel structure, where the consequences of the decisions taken can even lead to opposite results, including towns getting better positioned for commerce in a national context while their regions see their options curtailed. Of course, other network science tools may be applied to a well-established historical sequence to look for the effects of other types. The use of all those diagnostic tools, combined with agent-based modeling flexible enough to incorporate different decision-making procedures, may prove very useful in dealing with the future development of infrastructures and related systems. Our methodology provides a guide to take many arguments out of the political arena and into socioeconomic reality in a manner that can be used to benefit society at large. The fact that we have considered the specific case of roads in the eighteenth century Spain should not hide the applicability of the method; in 
particular, we envisage that in the context of cities (Batty 2013) our approach can be very fruitful.

Acknowledgements This work has been supported in part by Ministerio de Economía, Innovación y Competitividad (Spain) through Grants PGC2018-098186-B-I00 (BASIC, FEDER/MICINNAEI), PRACTICO-CM and CAVTIONS-CM-UC3M (Comunidad de Madrid/Universidad Carlos III de Madrid), CSO2016-74888-C4-4-R (CITITALENT, AEI/FEDER, UE), and H2019/HUM-5761 (INNJOBMAD-CM), COVID-19 UAH 2019/00003/016/001/007. We thank Rafael Myro, Javier Callealta, Alfonso Herranz-Loncán, and IX Iberometrics meeting participants for their helpful comments. We are also thankful to the anonymous Reviewers whose suggestions were of great help in producing this version of the manuscript.

\section{Appendix}

The allocation of effects at the regional level is complicated by the changes in the territorial division that occur during the period. The territorial division of the early eighteenth century was chosen for the calculations. The use of the current territorial division does not seem appropriate as both local identities and internal borders affecting trade do not exactly correspond to this division. The explicit incorporation of toll gates would have been desirable but is not possible because

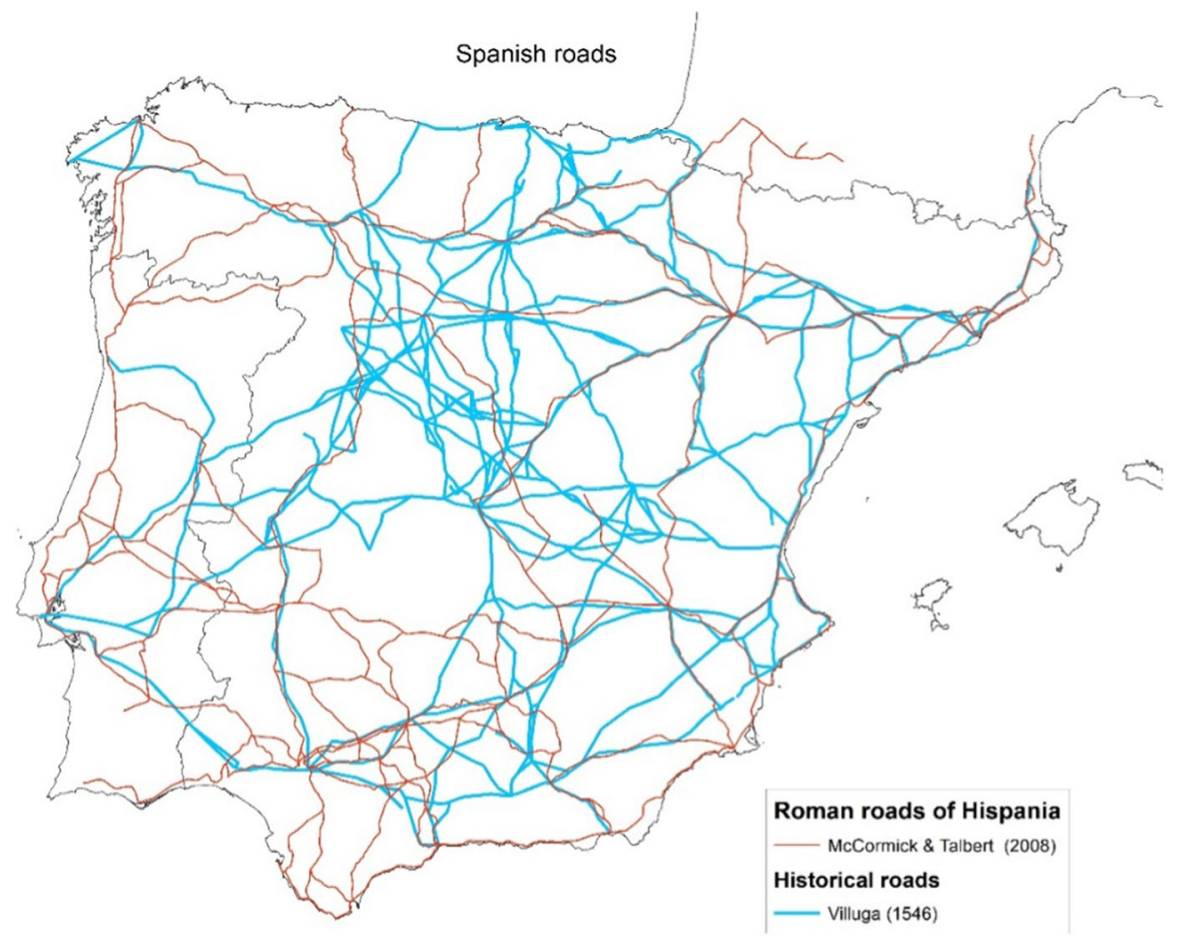

Fig. 21 Comparison of the Roman network and the Villuga's itineraries of the 16th century. Source: own elaboration 


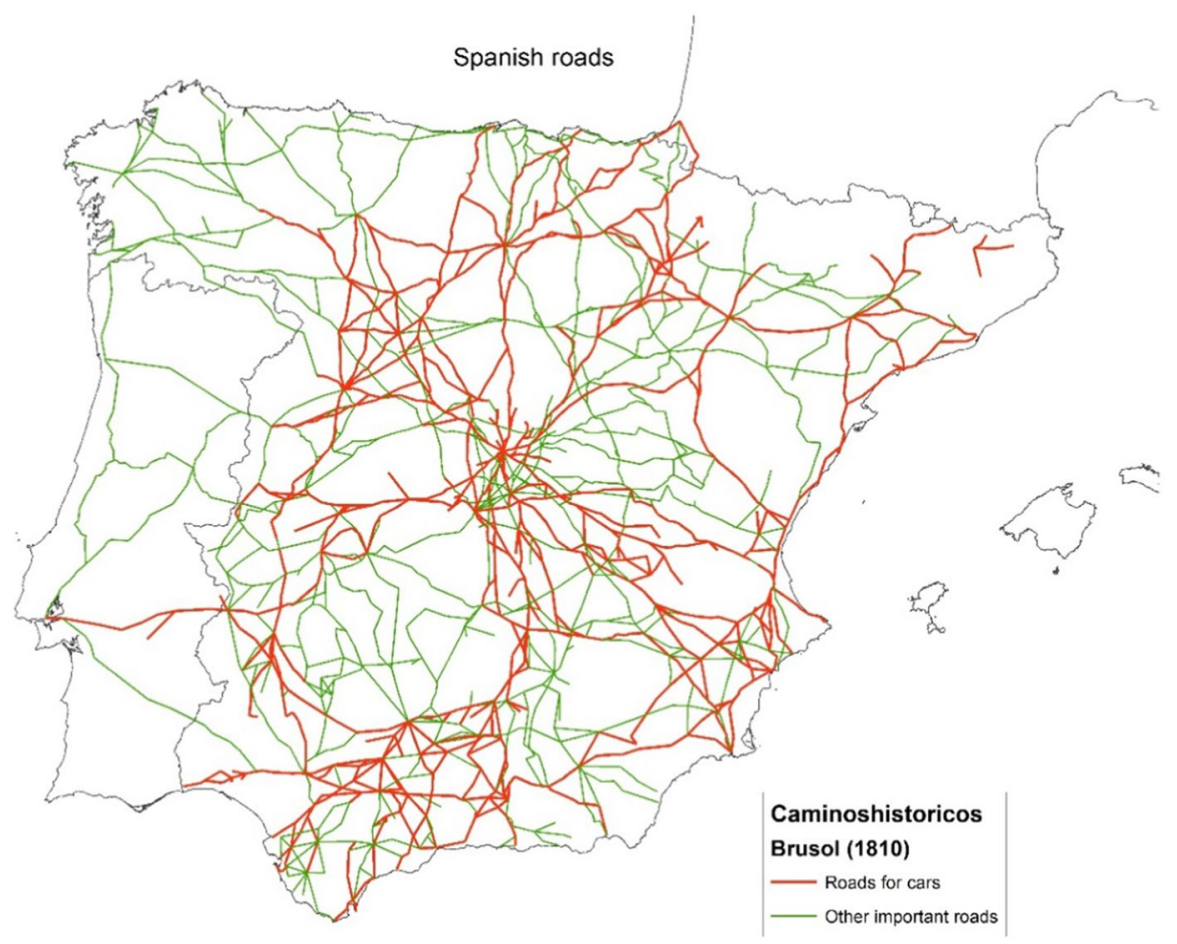

Fig. 22 Roads map of Anonymous (1810). Source: own elaboration

the available information is incomplete and spatially biased (Madrazo Madrazo 1982).

Specifically, the map used as a regional reference for all the periods is that of (Sanson 1700) as it refers to the beginning of the period analyzed and is the map he used (Martínez de Grimaldo 1720) to establish his post routes. To assign the villages included in the analysis to the different regions, the map was rectified to adjust it to the spatial reality of the territory (Figs. 21, 22, 23, Table 4).

The main changes in the regional division of Spain during the period according to the cartography of the time:

- Sanson and Tavernier (1641): Extremadura as an autonomous region.

- Sanson (1700): The same division as that of 1641 but Extremadura is now part of New Castile except for the north of Caceres which is included in Old Castile.

- Chatelain (1706): Extremadura is an autonomous region, although it is the only region without its coat of arms. The north still belongs to Old Castile.

- Homann (1750): Extremadura integrates its northern zone. 


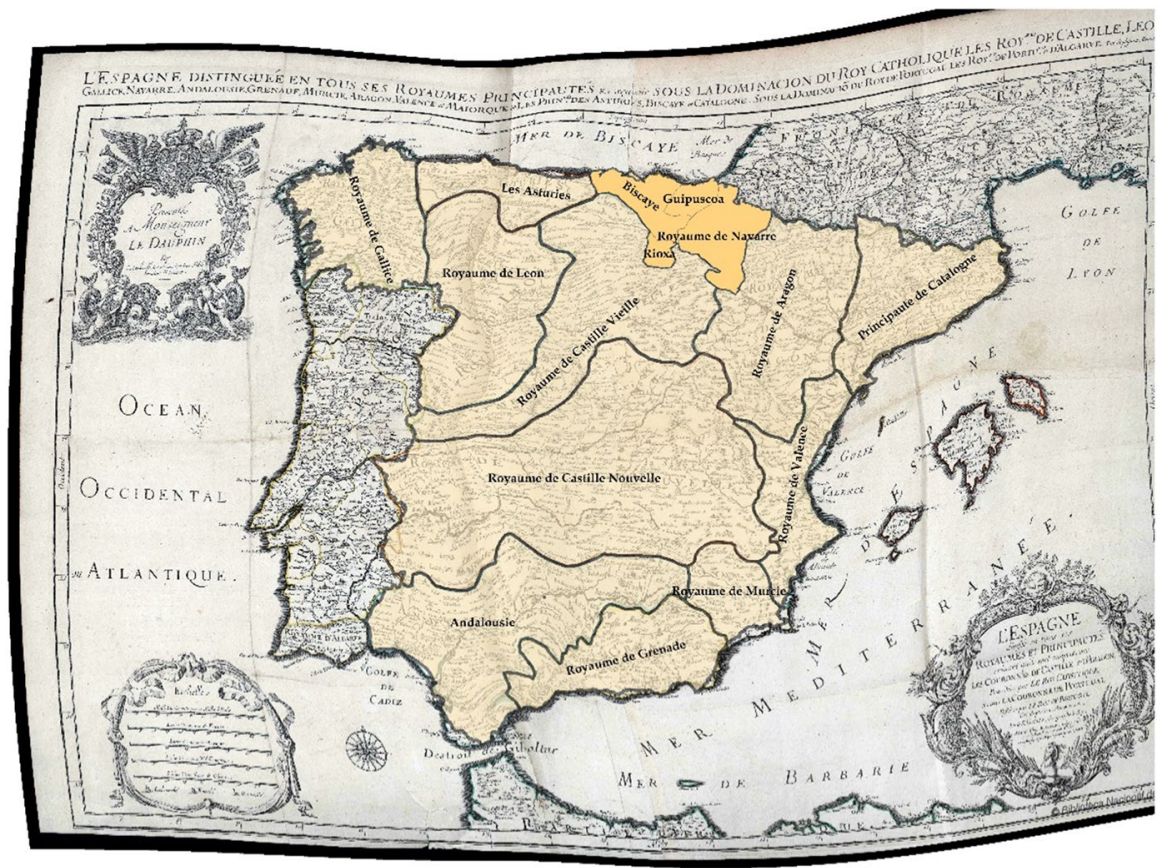

Fig. 23 Territorial division of Spain. Source: Sanson (1700) and own elaboration

Table 4 Average betweenness centrality by regions. Source: Own elaboration

$\begin{array}{lllllll}1700 & 1750 & 1780 & 1820 & 1850 & \begin{array}{l}\text { Growth } \\ (1750-1850)\end{array} & \begin{array}{l}\text { Deviation from } \\ \text { nation }(\%)\end{array}\end{array}$

(\%)

\begin{tabular}{lrrrrrrr}
\hline Andalusia & $24,412.5$ & $24,852.1$ & $26,489.5$ & $33,416.3$ & $31,082.7$ & 27.3 & -3.3 \\
Aragon & $42,788.2$ & $42,576.6$ & $42,079.1$ & $49,547.8$ & $50,029.3$ & 16.9 & -40.1 \\
New Castile & $40,665.5$ & $40,054.3$ & $41,983.5$ & $62,452.0$ & $64,018.0$ & 57.4 & 103.3 \\
Old Castile & $51,418.0$ & $49,852.5$ & $53,952.5$ & $56,510.5$ & $55,550.3$ & 8.0 & -71.6 \\
Catalonia & $24,585.9$ & $24,581.7$ & $25,205.8$ & $33,896.7$ & $34,300.0$ & 39.5 & 39.9 \\
Galicia & $17,122.6$ & $17,241.0$ & $17,770.4$ & $18,930.8$ & $21,649.2$ & 26.4 & -6.4 \\
Granada & $10,090.4$ & $10,113.2$ & 9794.8 & 6680.4 & $19,516.1$ & 93.4 & 230.7 \\
Guipuzcoa* & 8275.8 & 8112.7 & 8312.5 & $21,158.9$ & $22,929.6$ & 177.1 & 526.8 \\
La Rioja* & $71,435.8$ & $70,379.4$ & $69,671.4$ & 6123.6 & 8827.6 & -87.6 & -410.2 \\
Las Asturias & $12,950.1$ & $11,922.5$ & 9425.2 & 5553.0 & 4104.1 & -68.3 & -341.8 \\
Leon & $47,556.6$ & $48,311.1$ & $48,424.5$ & $48,369.7$ & $43,056.6$ & -9.5 & -133.5 \\
Murcia & $15,051.2$ & $15,055.9$ & $14,830.9$ & $19,572.4$ & $18,726.6$ & 24.4 & -13.6 \\
Navarre* & $28,700.0$ & $28,453.4$ & $28,225.1$ & $21,778.6$ & $34,697.2$ & 20.9 & -26.0 \\
Valencia & $31,623.4$ & $31,632.8$ & $35,478.3$ & $40,862.9$ & $46,724.0$ & 47.8 & 69.0 \\
Vizcaya* & $15,534.0$ & $16,738.7$ & $18,231.7$ & $14,570.7$ & $14,786.5$ & -4.8 & -117.0 \\
SPAIN & $32,772.7$ & $32,576.6$ & $33,802.4$ & $40,711.5$ & $42,030.8$ & 28.2 & 0.0 \\
CV & 0.57 & 0.56 & 0.57 & 0.59 & 0.52 & & \\
CV* & 0.46 & 0.46 & 0.48 & 0.57 & 0.50 & & \\
\hline
\end{tabular}


- López de Vargas y Machuca (1802): The Kingdom of Granada is integrated into Andalusia. The Kingdom of León incorporates Valladolid, Palencia, and the Principality of Asturias. The Crown of Aragon integrates the four historic kingdoms. Old Castile incorporates Santander, which belonged to Biscay, and gets the sea outlet.

- After the Napoleonic War, the regions lost importance in favor of the new provinces. In any case, the map of Martín de López (1834) allows how these are integrated for the old kingdoms. Valladolid and Palencia return to Old Castile. The historical kingdoms of the Crown of Aragon are differentiated again. Murcia now includes Albacete.

\section{References}

Adamatzky A (2012) The world's colonization and trade routes formation as imitated by slime mould. Int J Bifurcation Chaos 22(08):1230028. https://doi.org/10.1142/S0218127412300285

Adamatzky A, Alonso-Sanz R (2011) Rebuilding Iberian motorways with slime mould. BioSystems 105(1):89-100. https://doi.org/10.1016/j.biosystems.2011.03.007

Aggarwal S (2018) Do rural roads create pathways out of poverty? Evidence from India. J Dev Econ 133:375-395. https://doi.org/10.1016/j.jdeveco.2018.01.004

Allard A (1710) Weg-Wyzer Der Legertogten in Spanje En Portugaal=Theatrum Martis in Hispania et Portugallia. https://www.ign.es/web/catalogo-cartoteca/resources/html/023426.html. Accessed 19 Sept 2019

Alvar Ezquerra A (1985) Felipe II, La Corte y Madrid En 1561. Madrid: Centro de Estudios Históricos. CSIC

Andree L (1597) Kronn Und Auszbunde Aller Wegweiser. Darinne Verzeichnet Seindt Alle Die Wege, so Gehen Ausz 71. Den Vornembsten Städten von Teutschland, 17t. von Niderlandt, 39. von Frankreich, 29 von Italia, Und 31. von Hispania. Colonia. https://play.google.com/store/books/detai ls?id=P3RYAAAAcAAJ\&rdid=book-P3RYAAAAcAAJ\&rdot=1. Accessed 19 Sept 2019

Anes G (1974) El Antiguo Régimen: Los Borbones. Alianza Editorial, Madrid

Anes G (1983) La Agricultura Española y El Mercado Americano. In: Anes G, Rojo LÁ, Tedde P (eds) Historia Económica y Pensamiento Social: Estudios En Homenaje a Diego Mateo Del Peral. Alianza Editorial, Madrid, pp 193-204

Anonymous (1810) Noticia de Todas Las Ciudades, Villas y Lugares de Este Reyno de España Con Las Leguas Que Median Entre Sí, Tanto Por Los Caminos de Ruedas, Como Por Los de Herradura. Francisco Brusòla, Valencia

Anonymous, Pontón P (1705) Guía de Caminos Para Ir, y Venir Por Todas Las Provincias Más Afamadas de España, Francia, Italia y Alemania. Añadida a La Regla General Para Saber Adonde Se Escrive Los Dias de Correo. Madrid: Francisco Martinez Abad

Aranaz del Río F (2005) Postas y caminos en la cartografía postal española. Academus 9:49-77

Arbia G (2001) Modelling the geography of economic activities on a continuous space. Pap Region Sci 80(4):411-424. https://doi.org/10.1007/PL00013646

Arthur WB (1989) Competing technologies, increasing returns, and lock-in by historical events. Econ J 99(394):116-131

Artola M, Anes R, Tedde P (1978) Los Ferrocarriles En España. 1844-1943- II. Los Ferrocarriles y La Economía. Servicio de Estudios del Banco de España, Madrid

Asher S, Paul N (2016) Market access and structural transformation: evidence from rural roads in India. Manuscript: Department of Economics

Atack J (2013) On the use of geographic information systems in economic history: the American transportation revolution revisited. J Econ Hist 73(2):313-339. https://doi.org/10.1017/S0022 050713000284.Jeremy

Badenoch A (2010) Myths of the European network: construction of cohesion in infrastructure maps. In: Badenoch A, Fickers A (eds) Materializing Europe: transnational infrastructures and the project of Europe. Palgrave Macmillan, New York 
Bairoch P (1974) Geographical structure and trade balance of European foreign trade from 1800 to 1970. J Eur Econ Hist 3(3):557-608

Barceló J, Codina E, Casas J, Ferrer JL, García D (2005) Microscopic traffic simulation: a tool for the design, analysis and evaluation of intelligent transport systems. J Intell Robot Syst: Theory Appl 41(2-3):173-203. https://doi.org/10.1007/s10846-005-3808-2

Barro RJ, Sala-i-Martin X (1992) Convergence. J Polit Econ 100(2):223-251. https://doi. org/10.1086/261816

Barthélemy M (2011) Spatial networks. Phys Rep 499(1-3):1-101. https://doi.org/10.1016/j.physr ep.2010.11.002

Barthelemy M (2018) Betweenness centrality. In: Morphogenesis of Spatial Networks. Lecture Notes in Morphogenesis. Springer, Cham. https://doi.org/10.1007/978-3-319-20565-6_4

Batty M (2013) The new science of cities. MIT Press, Cambridge

Bednar J, Page SE, Toole JL (2012) Revised-path dependence. Polit Anal 20(2):146-156. https://doi. org/10.1093/pan/mpr051

Bel G (2010) España, capital París. Ediciones Destino, Barcelona

Bel G (2011) Infrastructure and nation building: the regulation and financing of network transportation infrastructures in Spain (1720-2010). Bus Hist 53(5):688-705. https://doi.org/10.1080/00076 791.2011 .599591

Berger T, Enflo K (2017) Locomotives of local growth: the short- and long-term impact of railroads in Sweden. J Urban Econ 98:124-138. https://doi.org/10.1016/j.jue.2015.09.001

Betancourt A (1868) Noticia Del Estado Actual de Los Caminos y Canales de España, Causas de Sus Atrasos y Defectos, y Medios de Remediarlos En Adelante; Dada Al Excmo. Sr. D. Pedro Cevallos Por D. Agustín de Betancourt_Año de 1803. Revista de Obras Públicas, no. 5, 6, 10 and 13: 54-58, 68-71, 115-16 and 156-58. http://ropdigital.ciccp.es/detalle_articulo.php?regis tro $=1545 \&$ anio $=1869 \&$ numero_revista $=5$. Accessed 18 Oct 2019

Bleakley H, Lin J (2012) Portage and path dependence. Quart J Econ 127(2):587-644. https://doi. org/10.1093/qje/qjs011

Borsano A (1687) El Principado de Cattaluña y Condados de Rossellon y Cerdaña Hecho En El Espacio de XII Años Por El Mre. de Campo D. Ambrosio Borsano, Quartel Mre. Genl. y Ingeniero Mayor Del Real Exercito de Cattaluña, En Que Estan Descritos Todas Las Veguerias, Collect. http://bdh. bne.es/bnesearch/detalle/bdh0000036323. Accessed 19 Sept 2019

Braudel F (1976) El Mediterráneo y el mundo mediterráneo en la época de Felipe II. Tomo 1. Fondo de Cultura Económica, México

Brion de la Tour L, Desnos LC (1766) Carte d'Espagne et de Portugal, Comprenant Les Routes de Poste et Autres de Ces Deux Roiaumes. Louis-Charles Desnos, Paris. https://commons.wikimedia.org/ wiki/File:Carte_dEspagne_et_de_Portugal,_comprenant_les_routes_de_poste_et_autres_de_ces_ deux_roiaumes_(4586560269).jpg. Accessed 19 Sept 2019

Brown DG, Page S, Riolo R, Zellner M, Rand W (2005) Path dependence and the validation of agentbased spatial models of land use. Int J Geogr Inf Sci 19(2):153-174. https://doi.org/10.1080/13658 810410001713399

Brughmans T (2013) Thinking through networks: a review of formal network methods in archaeology. J Archaeol Method Theory 20(4):623-662. https://doi.org/10.1007/s10816-012-9133-8

Calderón C, Servén L (2004) The effects of infrastructure development on growth and income distribution (English). Policy, Research working paper; no. WPS 3400 Washington, D.C. : World Bank Group. http://documents.worldbank.org/curated/en/438751468753289185/The-effects-of-infra structure-development-on-growth-and-income-distribution. Accessed 19 Sept 2020

Carr R (1978) España 1808-1939. Ariel, Barcelona

Carreras Monfort C, de Soto P (2010) Historia de la movilidad en la Península Ibérica: redes de transporte en SIG. Universitat Oberta de Catalunya, Barcelona

Carreras Montfort C, de Soto P (2013) The Roman transport network: a precedent for the integration of the European mobility. Histor Methods: J Quant Interdisc Hist 46(3):117-133. https://doi. org/10.1080/01615440.2013.803403

Casson M (2009) The efficiency of the Victorian British railway network - a counterfactual analysis. Netw Spat Econ 9(3):339-378. https://doi.org/10.1007/s11067-008-9064-9

Chatelain HA (1706) Carte Historique et Geographique Des Royaumes d'Espagne et de Portugal Divises Selon Leurs Royaume et Provinces. Chez L'Honoré \& Chátelain Libraires, Amsterdam. https://dl.uc.pt/explore?bitstream_id=5686185\&handle=10316.2/43557\&provider=iiif-image $\#$ ? $=0$ \&m $=0 \& \mathrm{~s}=0 \& \mathrm{cv}=0 \& x y w h=-3889 \% 2 \mathrm{C}-635 \% 2 \mathrm{C} 22068 \% 2 \mathrm{C} 12683$. Accessed 18 Oct 2019 
Codogno O (1608) Novo Itinerario Delle Poste Per Tutto Il Mondo Di Ottaviano Codogno. Luogortenente Del Corriero Maggiore Di Milano. Girolamo Bordoni, Milano

Comín Comín F, Martín Aceña P, Muñoz Rubio M, Vidal Olivares J (1998) 150 años de historia de los ferrocarriles españoles. Anaya, Madrid

Correas P (1988) Poblaciones españolas de más de 5000 habitantes entre los siglos XVII y XIX. Boletín de la Asociación de Demografía Histórica, 6(1):5-23

Crescenzi R, Rodríguez-Pose A (2012) Infrastructure and regional growth in the European Union. Pap Region Sci 91(3):487-513. https://doi.org/10.1111/j.1435-5957.2012.00439.x

Cuenca-Esteban J (2008) Statistics of Spain's colonial trade, 1747-1820: new estimates and comparisons with Great Britain. Revista de Historia Economica-J Iber Latin Am Econ Hist 26(3):323-354. https://doi.org/10.1017/S0212610900000379

D’Ocampo F (1544) Los Quatro Libros Primeros de La Cronica General de España. Juan Picardo, Zamora. https://books.google.es/books?id=1yRhAAAAcAAJ\&dq=caminos\&hl=es\&source=gbs_ similarbooks. Accessed 18 Oct 2019

David PA (1985) Clio and the economics of QWERTY. Am Econ Rev 75(2):332-337

de Ayala S (1821) Guia General de Postas y Travesías de España Segun Estan En El Dia. Mateo Repullés, Madrid

de B F, de Grieck J (1704) Voyages Historiques De L'Europe: Ou Les Delices De La France, D'Espagne, d'Italie, d'Allemagne, d'Angleterre. Josse de Grieck, Brussels. https://play.google.com/store/books/ details?id=_3hCAAAAcAAJ\&rdid=book-_3hCAAAAcAAJ\&rdot=1. Accessed 19 Sept 2020

de Cabanes FJ, González Salmón MG (1829) Mapa Itinerario de Los Reinos de España y Portugal Dedicado Al Rey N.S. D. Fernando VII de Borbón. http://bdh.bne.es/bnesearch/detalle/bdh0000031 143. Accessed 19 Sept 2019

de Fer N (1704) L' Espagne Triomphante Sous Le Règne de Philippe Vme. http://bdh-rd.bne.es/viewe r.vm?id=0000019419. Accessed 18 Oct 2019

de Fer N, Loon HV (1701) Espagne et Portugal : Divisés En Ses Principales Parties OuRoyaumes. http:// cartotecadigital.icc.cat/cdm/singleitem/collection/espanya/id/927/rec/286. Accessed 18 Oct 2019

de Gregorio - Marqués de Esquilache (1761) Copia Del Real Decreto Expedido Para Hacer Caminos Rectos, y Sólidos En España, Que Faciliten El Comercio de Unas Provincias á Otras, Dando Principio Por Los de Andalucia, Cathaluña, Galicia, y Valencia. El Marquès de Squilace. Aranjuez. https://play.google.com/store/books/details?id=7shko0BiWrkC\&rdid=book-7shko0BiWr $\mathrm{kC} \& \mathrm{rdot}=1$. Accessed 18 Oct 2019

de Ita F, Xareño JV (1789) Atlas Geografico de Correos, Postas, y Estafetas de La Peninsula de España. vol 1. Madrid

de Jovellanos GM (1795) Informe de La Sociedad Económica de Esta Corte Al Real y Supremo Consejo de Castilla En El Expediente de Ley Agraria. Edited by Real Sociedad Económica de Amigos del País. Gabriel de Sancha, Madrid. http://bdh.bne.es/bnesearch/detalle/bdh0000038338. Accessed 18 Oct 2019

de Laborde A (1808) Itinéraire Descriptif de l'Espagne, et Tableau Élémentaire Des Différentes Branches de l'administration et de l'industrie de Ce Royaum. H. Nicolle, Paris

de Mayerne TT (1605) Sommaire Description de La France, Allemagne, Italie, Espagne: Avec La Guide Des Chemins Pour Aller et Venir Par Les Provinces, et Aux Villes plus Renommés de Ces Quatre Regions. vol 6. J. Stoer. https://www.e-rara.ch/gep_r/doi/10.3931/e-rara-51022. Accessed 18 Oct 2019

de Meneses A (1568) Memorial õ abecedario de los mas principales caminos de España. Ordenado por Alonso de Meneses correo. Va por abecedario: como por la tabla se vera. Con el camino de Madrid a Roma. Juan de Ayala, Toledo

de Meneses A (1576) Reportorio de Caminos. Ordenado Por Alonso de Meneses Correo. Añadido El Camino de Madrid a Roma. Con Un Memorial de Muchas Cosas Sucedidas En España. Y Con El Reportorio de Cuentas, Conforme a La Nueva Pragmatica. Third ed..Sebastian Martinez, Alcalá de Henares

de Nooy W, Mrvar A, Batagelj V (2005) Exploratory social network analysis with pajek. Cambridge University Press, New York

de Quintana JI (1753) Methodo General Para Todas La Vias de España, Por Cuyo Medio Logra El Público de La Mayor Utilidad, Consiguiendo Por Poco Porte La Conducción de Todos Los Generos, y Frutos de Unas Provincias a Otras. Domingo Fernánde de Arrojo, Madrid. https://play.googl e.com/books/reader?id=iZggIg-IbSAC\&hl=es\&printsec=frontcover\&pg=GBS.PP1. Accessed 18 Oct 2019 
de Soto P (2019) Network analysis to model and analyse Roman transport and mobility. Find Limit Limes. https://doi.org/10.1007/978-3-030-04576-0_13

de Wit F (1700) Nova et Accurata Totius Hispaniae Tabula Emendata a F. De Wit. Joachim. Ottens, Amsterdam. http://cartotecadigital.icgc.cat/cdm/singleitem/collection/espanya/id/2529/rec/1. Accessed 18 Oct 2019

Delgado Ribas JM (1986) Comercio colonial y crecimiento económico en la España del siglo XVIIIla crisis de un modelo interpretativo. Manuscrits: Revista d'història Moderna 3:23-40

Depósito de la Guerra (1865) Mapa Itinerario Militar de España. http://bvpb.mcu.es/es/consulta/registro. cmd?id=434680. Accessed 18 Oct 2019

Díez-Minguela A, Martínez-Galarraga J, Tirado-Fabregat DA (2016) Why did spanish regions not converge before the civil war? agglomeration economies and (regional) growth revisited. Revista de Historia Economica-J Iber Latin Am Econ Hist 34(3):417-448. https://doi.org/10.1017/S0212 610915000300

Dijkstra EW (1959) A note on two problems in connexion with graphs. Numer Math 1:269-271

Dirección General de Obras Públicas (1856) Memoria sobre el estado de las obras públicas en España en 1856. Imprenta Nacional, Madrid

Downs RM, Stea D (1977) Maps in minds: reflections on cognitive mapping. Harper and Row series in geography. Harper \& Row, Manhattan

Dubert García I (2008) Comercio y Tráfico Marítimo En La Galicia Del Antiguo Régimen, 1750-1820. Obradoiro de Historia Moderna 17:211-243. https://doi.org/10.15304/ohm.17.455

Duval P (1659) Le Voyage de Madrid et Le Chemin de St Iacqves En Galice. Paris: Baillieul, Gaspard. http://gallica.bnf.fr/ark:/12148/btv1b8493308t.r=galice. Accessed 18 Oct 2019

Ell PS, Gregory IN (2001) Adding a New Dimension to Historical Research with GIS. History and Computing 13(1):1-6

Escribano JM (1758) Itinerario Español o Guía de Caminos, Para Ir Desde Madrid à Todas Las Ciudades de España, y Sus Mas Principales Villas, y Puertos de Mar, y Para Ir de Unas Ciudades à Otras. Miguel Escribano, Madrid

Espinalt y García B (1775) Mapa de España Dividido En Todos Sus Reinos, Provincias y Principados, En Donde Estan Exactamente Observadas Todas Las Rutas de Postas y Caxas de Correo. http://bibli otecavirtualdefensa.es/BVMDefensa/i18n/consulta/registro.cmd?id=36491. Accessed 18 Oct 2019

Espinalt y García B (1804) Mapa de Las Carreras de Postas de España : Dedicado Al Excmo. Sr. Dn. Pedro Cevallos. http://bdh.bne.es/bnesearch/detalle/bdh0000035630. Accessed 19 Sept 2020

Estienne C (1552) Les Voyages de Plusieurs Endroits de France \& Encores de La Terre Saincte, d'Espaigne, d'Italie \& Autres Pays : Les Fleuves Du Royaume de France. Paris: Chez Charles Etienne. https://gallica.bnf.fr/ark:/12148/bpt6k102662d. Accessed 19 Sept 2020

Equipo Urbano (1972) Simulación de una red de transportes. El caso de los ferrocarriles españoles. Revista de geografia 6(1):34-54

Evangelidis V, Tsompanas MA, Sirakoulis Georgios Ch, Adamatzky A (2015) Slime Mould Imitates Development of Roman Roads in the Balkans. Journal of Archaeological Science: Reports 2:264281. https://doi.org/10.1016/j.jasrep.2015.02.005

Faber B (2014) Trade integration, market size, and industrialization: evidence from China's national trunk highway system. Rev Econ Stud 81(3):1046-1070. https://doi.org/10.1093/restud/rdu010

Fernández de Mesa TM (1755) Tratado legal, y político de caminos públicos y possadas dividido en dos partes. Joseph Thomas Lucas, Valencia. http://bibliotecadigital.jcyl.es/es/consulta/registro. cmd?id=4575. Accessed 18 Oct 2019

Fernández-de Pinedo Echevarría N, Fernández-de Pinedo Fernández E (2013) Distribution of english textiles in the Spanish market at the beginning of the 18th century. Revista de Historia Económica 31(2):253-284. https://doi.org/10.1017/S0212610913000116

Frax E (1981) Puertos y comercio de cabotaje en España, 1857-1934. Banco de España, Servicio de Estudios, Madrid

Franquet Bernis JM, Albacar Damian MÁ, Tallada de Esteve F (2017) Problemática del río Ebro en su tramo final: informe acerca de los efectos sobre el área jurisdiccional de la Comunidad de Regantes - Sindicato Agrícola del Ebro. UNED-Tortosa. http://e-spacio.uned.es/fez/eserv/bibliuned:UNEDC entroAsociadoTortosa-Libros-5040/Franquet_Bernis_Problematica.pdf. Accessed 19 Sept 2020

Gail J (1563) "Raißbüchlin”. Ein Neuwes Nützliches Raißbüchlin Der Furnemesten Land Vnnd Stett, Durch Mich, Jörg Gail, Burger Zu Augspurg in Truck Verfertiget. Augsburg

Galor O, Mountford A (2008) Trading population for productivity: theory and evidence. Rev Econ Stud 75(4):1143-1179. https://doi.org/10.1111/j.1467-937X.2008.00501.x 
Garcia-López M-À (2012) Urban spatial structure, suburbanization and transportation in Barcelona. J Urban Econ 72(2-3):176-190. https://doi.org/10.1016/j.jue.2012.05.003

Garcia-López M-À, Holl A, Viladecans-Marsal E (2015) Suburbanization and highways in Spain when the Romans and the Bourbons still shape its cities. J Urban Econ 85:52-67. https://doi. org/10.1016/j.jue.2014.11.002

Garud R, Karnøe P (2001) Path creation as a process of mindful deviation. In: Garud R, Karnoe P (eds) Path Dependence and Creation. Lawrence Erlbaum, London, pp 1-38

Ghani E, Goswami AG, Kerr WR (2016) Highway to success: the impact of the golden quadrilateral project for the location and performance of indian manufacturing. Econ J 126(591):317-357. https:// doi.org/10.1111/ecoj.12207

Gómez Mendoza A (1982) Ferrocarriles y cambio económico en España (1855-1913): Un enfoque de nueva historia económica. Alianza Editorial, Madrid

Gómez Mendoza A (2001) Madrid, Centro de La Red de Comunicaciones. Arbor 666(5):343-358

Grafe R (2012) Distant tyranny: markets, power, and backwardness in Spain, 1650-1800. Princeton University Press, Princeton

Guilleminot LGC, Wahl R, Picquet C (1823) Carte-Itinéraire de L'Espagne et Du Portugal: Dressé Par Ordre de S. E. M. Le Maréchal Duc de Bellune, Ministre de La Guerre. Dépôt de la Guerre, Paris. http://bibliotecavirtualdefensa.es/BVMDefensa/i18n/consulta/registro.cmd?id=36584. Accessed 19 Sept 2020

Gutmann MP, Merchant EK, Roberts E (2018) 'Big data' in economic history. J Econ Hist 78(1):268299. https://doi.org/10.1017/S0022050718000177

Healey RG, Stamp TR (2000) Historical GIS as a foundation for the analysis of regional economic growth: theoretical, methodological, and practical issues. Soc Sci Hist 24(3):575-612. https://doi. org/10.1017/S0145553200010300

Herranz-Loncán A (2005) La reducción de los costes de transporte en España (1800-1936). Cuadernos Económicos de ICE 70:183-203

Herranz-Loncán A (2006) The spatial distribution of Spanish transport infrastructure between 1860 and 1930. Ann Reg Sci 41:189-208. https://doi.org/10.1007/s00168-006-0096-0

Holl A (2011) Factors influencing the location of new motorways: large scale motorway building in Spain. J Transp Geogr 6:1282-1293. https://doi.org/10.1016/j.jtrangeo.2011.06.006

Holl A (2012) Market potential and firm-level productivity in Spain. J Econ Geogr 12(6):1191-1215. https://doi.org/10.1093/jeg/lbr030

Holl A (2016) Highways and productivity in manufacturing firms. J Urban Econ 93:131-151. https://doi. org/10.1016/j.jue.2016.04.002

Homann JB (1750) El Reyno de Espanna Dividido En Dos Grandes Estados de Aragon y de Castilla, Subdividido En Muchas Provincias, Donde Se Halla Tambien El Reyno de Portugal. Nuremberg. http://cartotecadigital.icc.cat/cdm/singleitem/collection/espanya/id/1952/rec/2. Accessed 18 Oct 2019

Homann JB, Remshard K (1710) Hispaniae et Portugalliae Regna : Felicissimo Nuper Adventu Classico Caroli III. Austriaci, Hispaniarum and Indiarum Regis \&c. Fortunata Exhibente Io. Bapt. Homan[n]o Nuremberg. http://bdh.bne.es/bnesearch/detalle/bdh0000019634. Accessed 18 Oct 2019

Horni A, Nagel K, Axhausen KW (2016) The Multi-Agent Transport Simulation MATSim. Ubiquity Press, London

Jaillot AH, Martínez de Grimaldo J (1721) L' Espagne Divisée En Tous Ses Royaumes et Principautés Où Sont Exactement Recueillies et Obervées [Sic] Toutes Les Routes Des Postes d'Espagne, Sur Les Memoires Des Courriers Majors de Madrid. Jaillot, Paris. https://gallica.bnf.fr/ark:/12148/ btv1b53057030d. Accessed 19 Sept 2020

Jedwab R, Moradi A (2016) The permanent effects of transportation revolutions in poor countries: evidence from Africa. Rev Econ Stat 98(2):268-284. https://doi.org/10.1162/REST_a_00540

Jedwab R, Kerby E, Moradi A (2017) History, path dependence and development: evidence from colonial railways, settlers and cities in Kenya. Econ J 127(603):1467-1494. https://doi.org/10.1111/ ecoj. 12347

Jenny B, Hurni L (2011) Studying cartographic heritage: analysis and visualization of geometric distortions. Comput Gr 35(2):402-411. https://doi.org/10.1016/j.cag.2011.01.005

Juncà Ubierna JA (1997) 1. Historia de Los Túneles y Su Evolución Histórica. In: López Jimeno C (ed) Manual de Túneles y Obras Subterráneas, Vol. 1. Arias Montano, Madrid, pp 1-10 
Kolars J, Malin HJ (1970) Population and accessibility: an analysis of Turkish railroad. Geogr Rev 60(2):229-246. https://www.jstor.org/stable/213682

Lang W (1950) The Augsburg Travel Guide of 1563 and the Erlinger Road Map of 1524. Imago Mundi 7(1):85-88. https://doi.org/10.1080/03085695008591960

Lee R (1998) The socio-economic and demographic characteristics of port cities: a typology for comparative analysis? Urban Hist 25(2):147-172. https://doi.org/10.1017/s096392680000078x

Líter Mayayo C (2005) Cartografía y comunicaciones en los documentos de la Biblioteca Nacional. Siglos XVI al XIX. Academus 9:29-47

Lobeto Lobo R (1989) La Marina Mercante Decimonónica. Cuadernos Monográficos del Instituto de Historia y Cultura Naval 5:139-146

López de Vargas y Machuca T (1760) Mapa de Las Carreras de Postas de España. Dedicado Al Rey N. S. D. Carlos III Por Mano Del Exmo, Sr. D.Ricardo Wall, Caballero Comendador de La Orden de Santiago, Del Consejo de Estado de S. M.C., Su Primer Secretario de Estado y de Guerra, Superintendente General de Correos, Postas y Estafetas de dentro y fuera de España. http://atlaspostal.afine t.org/02/wall1760.htm. Accessed 19 Sept 2020

López de Vargas y Machuca T (1802) Mapa General de España Dividido En Sus Actuales Provincias Islas Adyacentes y Reyno de Portugal. Madrid: Se hallará este con todas las obras del autor y las de su hijo en Madrid plazuela del Angel no 19 qto. Pral. http://bibliotecavirtualdefensa.es/BVMDe fensa/i18n/consulta/registro.cmd?id=36529. Accessed 18 Oct 2019

Lópéz de Vargas y Machuca T (1808) Carte Des Royaumes d'Espagne et de Portugal Óu l'on a Marqué Les Routes de Poste, et Les Limites Des Diverses Provinces et Gouvernements : Pour Servir à l'intelligence Des Opérations Militaires. Paris: E. Collin, Graveur Editeur, Rue St. Thomas du Louvre, $\mathrm{N}^{\circ}$ 22. http://bibliotecavirtualdefensa.es/BVMDefensa/i18n/consulta/registro.cmd?id=36534. Accessed 18 Oct 2019

López S (1809) Nueva Guía de Caminos Para Ir a Desde Madrid a Todas Las Ciudades y Villas Más Principales de España y Portugal, y También Para Ir de Unas Ciudades á Otras. Primera. Madrid: Gomez Fuentenebro y compañçia. https://play.google.com/books/reader?printsec=frontcover \&output $=$ reader\&id $=$ EOsrdlpIaAEC\&pg=GBS.PP1. Accessed 18 Oct 2019

López Ortiz MI, Melgarejo Moreno J (2016) Del atraso a la convergencia: La red de carreteras en España, 1900-2010. In: Vera Rebollo JF, Olcina Cantos J, Hernández Hernández M (ed) Paisaje, cultura territorial y vivencia de la geografía. Libro homenaje al profesor Alfredo Morales Gil 160:475531. Universidad de Alicante. Instituto Interuniversitario de Geografía, Alicante

Madrazo Madrazo S (1974) Tres arbitristas camineros de mediados del siglo XVIII. Hispania 34:126

Madrazo Madrazo S (1982) Portazgos y tráfico en la España de finales del antiguo régimen. Moneda y Crédito: Revista de Economía 160:39-84

Madrazo Madrazo S (1984a) El sistema de comunicaciones en España, 1750-1850: El trafico y los servicios, vol 2. Colegio de Ingenieros de Caminos, Canales y Puertos, Madrid

Madrazo Madrazo S (1984b) El sistema de comunicaciones en España, 1750-1850: La red viaria, vol 1. Colegio de Ingenieros de Caminos, Canales y Puertos, Madrid

Madrazo Madrazo S (1988) Reformas sin cambio. El mito de los caminos reales de Carlos III. In Carlos III, Madrid y la Ilustración, 27-48. Siglo XXI de España Editores, Madrid

Martin R (1999) The regional dimension in European public policy. Palgrave Macmillan, New York. https ://doi.org/10.1057/9780333982594

Martín de López P (1834) Mapa de España. Dividido En Sus Actuales Provincias, Yslas Adyacentes y Reyno de Portugal. Establecimiento Geográfico Calle del Príncipe, Madrid

Martín Mora P (2017) Pensando en el transporte. Revista del Ministerio de Fomento 674:42-54

Martin R, Sunley P (2006) Path dependence and regional economic evolution. J Econ Geogr 6(4):395437. https://doi.org/10.1093/jeg/lb1012

Martínez de Grimaldo J (1720) Reglamento General Expedido Por Su Magestad En 23 de Abril de 1720 Para La Direccion, y Govierno de Los Oficios de Correo Mayor y Postas de España. Juan Francisco de Blas, Sevilla

Martínez C, de la Vega C, de Somodevilla y Bengoechea Z (1743) Exposicion de las Operaciones Geometricas hechas por Orden del Rey N.S. Phelipe V. en todas las Audiencias Reales situadas entre los Limites de Francia y de Portugal para acertar a formar una mapa exacta y circonstanciada de toda la España. http://bdh.bne.es/bnesearch/Search.do?text=\&field2Op=AND\&field $1 \mathrm{val}=$ cartografia $\&$ numfields $=3 \&$ field $3 \mathrm{Op}=\mathrm{AND} \&$ field $3=$ todos $\&$ field 3 val $=\&$ field $2=$ todos $\&$ field $1 \mathrm{Op}=\mathrm{AND} \&$ exact $=\&$ advanced $=$ true $\&$ field $1=$ coleccion $\&$ media $=\&$ field $2 \mathrm{val}=\&$ language $=\mathrm{es}$. Accessed 18 Oct 2019 
Martínez-Galarraga J (2010) Market Integration and Regional Inequality in Spain, 1860-1930. Universitat de Barcelona. http://diposit.ub.edu/dspace/handle/2445/35756. Accessed 18 Oct 2019

Martinez-Galarraga J (2012) The determinants of industrial location in Spain, 1856-1929. Explor Econ Hist 49(2):255-275. https://doi.org/10.1016/j.eeh.2011.05.012

Martínez-Galarraga J (2013) El Potencial de Mercado Provincial En España, 1860-1930. Un Estudio de Nueva Geografía Económica e Historia Económica. Estudios de Historia Económica Banco de España 62:1-132. https://www.bde.es/f/webbde/SES/Secciones/Publicaciones/PublicacionesSe riadas/EstudiosHistoriaEconomica/Fic/roja62.pdf. Accessed 18 Oct 2019

Martínez-Galarraga J, Rosés JR, Tirado-Fabregat DA (2015) The long-term patterns of regional income inequality in Spain, 1860-2000. Reg Stud 49(4):502-517. https://doi.org/10.1080/00343 404.2013.783692

Martí-Romero J, San José A, Martí-Henneberg J (2020) The radiality of the railway network in Spain during its early stages (1830-1867). An assessment of its territorial coherence. Soc Sci Hist no. (forthcoming): $1-48$

Matal J, Hogenberg F (1579) Itinerarium Orbis Christiani. https://bildsuche.digitale-sammlungen.de/ index.html $? \mathrm{c}=$ viewer $\&$ bandnummer $=\mathrm{bsb} 00016475 \&$ pimage $=3 \& \mathrm{v}=150 \&$ nav $=\& 1=\mathrm{en} . \quad$ Accessed 18 Oct 2019

Mateo del Peral D (1978) Los orígenes de la Política ferroviaria en España (1844-1877). In: Artola M (ed) Los ferrocarriles en España. 1844-1943- I. El Estado y los ferrocarriles. Banco de España, Servicio de Estudios, Madrid, pp 29-159

Menéndez Pidal G (1951) Reportorio de Todos Los Caminos de España (Hasta Agora Nunca Visto) Juan Villuga 1546. In Los caminos en la historia de España. Ediciones Cultura Hispánica, Madrid

Miselli G (1697) Il Buratino Veridico. O Vero Inztruzzione Generale per Chi Viaggia. Giouanni La-Nou, Venice

Mitchener KJ (2015) The 4D Future of Economic History: digitally-Driven Data Design. J Econ Hist 75(4):1234-1239. https://doi.org/10.1017/S0022050715001655

Modarres A, Dierwechter Y (2015) Infrastructure and the Shaping of American Urban Geography. Cities 47:81-94. https://doi.org/10.1016/j.cities.2015.04.003

Molinas C (2013) Qué hacer con España. Del capitalismos castizo a la refundación de un país. Destino, Madrid

Moll H, Owles J, Overton P, Bowles T, John Arglie J (1711) A New and Exact Map of Spain \& Portugal : Divided into Its Kingdoms and Principalities \&c with Ye. Principal Roads and Considerable Improvements, the Whole Rectifyd According to Ye. Newest Observations. I. Bowles, London http://cartotecadigital.icc.cat/cdm/ref/collection/espanya/id/1867. Accessed 18 Oct 2019

Monzon A, Lopez E, Ortega E (2019) Has HSR improved territorial cohesion in Spain? An accessibility analysis of the first 25 years: 1990-2015. Eur Plan Stud 27(3):513-532. https://doi. org/10.1080/09654313.2018.1562656

Moreira M (2006) La importancia del mercado español en el comercio exterior portugués (1796-1831). Hispania Nova: Revista de Historia Contemporánea, 6:6. http://hispanianova.rediris.es/6/artic ulos/6a006.pdf. Accessed 18 Oct 2019

Mortier P (1710) Theatre de la guerre en Espagne et en Portugal. Amsterdam. https://cartotecadigita 1.icgc.cat/digital/collection/externs/id/68. Accessed 18 Oct 2019

Mortier P, Sanson N (1708) L'Espagne Divisée En Tous Ses Royaumes et Principautes. Amsterdam

Nadal J (1975) El fracaso de la Revolución Industrial en España, 1814-1913. Editorial Ariel, Madrid

Nakagaki T, Yamada H, Tóth Á (2001) Path finding by tube morphogenesis in an amoeboid organism. Biophys Chem 92(1-2):47-52. https://doi.org/10.1016/S0301-4622(01)00179-X

Nall C (2015) The political consequences of spatial policies: how interstate highways facilitated geographic polarization. J Polit 77(2):394-406. https://doi.org/10.1086/679597

Nall C (2018) The road to inequality: how the federal highway program polarized america and undermined cities. Cambridge Univeristy Press, Cambridge

Nantiat J, Laurie R, Whittle J (1810) A new map of Spain and Portugal : exhibiting the chains of mountains with their passes, the principal and cross road, with other details requisite for the intelligence of military operations. W. Faden, London. http://bibliotecavirtualdefensa.es/BVMDefensa/i18n/ consulta/registro.cmd?id=36535\&interno=S\&embebido=S. Accessed 18 Oct 2019

Naranjo Gómez JM (2016) Impacts on the social cohesion of mainland Spain's future motorway and high-speed rail networks. Sustainability 8(7):1-22. https://doi.org/10.3390/su8070624

Nunn N (2020) The historical roots of economic development. Science 367(6485). https://doi. org/10.1126/science.aaz9986 
Oliva Melgar JM (2004) El Monopolio de Indias en el siglo XVII y la economía andaluza: La oportunidad que nunca existió. Lección inaugural del curso académico 2004-2005. http://rabida.uhu.es/ dspace/bitstream/handle/10272/4339/b13589593.pdf?sequence=2. Accessed 19 Sept 2020

Pablo-Martí F, Sánchez A (2017) Improving transportation networks: effects of population structure and decision making policies. Sci Rep 7(1):4498. https://doi.org/10.1038/s41598-017-04892-2

Páez de Castro J, de Morales A, López de Velasco J (1578) Relaciones Topográficas de Felipe II. El Escorial

Perret J, Gribaudi M, Barthelemy M (2015) Roads and cities of 18th century France. Sci Data 2:1-12. https://doi.org/10.1038/sdata.2015.48

Peters D (2003) Old myths and new realities of transport infrastructure assessment: implications for EU interventions in Central Europe. In: Nellthorp J, Mackie P (eds) Transport Projects, Programmes and Policies: Evaluation Needs and Capabilities, 43-72. Ashgate, London

Picquet C, Lapì C, López de Vargas y Machuca T, Tofiño de San Miguel V (1810) Carte Des Routes de Postes et Itinéraires d'Espagne et Portugal. Paris: Chez Magimel, Libraire. http:/gallica.bnf.fr/ ark:/12148/btv1b53081348d/f1.item.zoom. Accessed 18 Oct 2019

Prados de la Escosura L (1986) Una serie anual del comercio exterior español (1821-1913). Revista de Historia Economica - J Iber Latin Am Econ Hist 4(1):103-150. https://doi.org/10.1017/S0212 610900014208

Prados de la Escosura L (2015) Spain's Historical National Accounts: Expenditure and Output, 18502015. Centre for Economic Policy Research Discussion Paper Series DP11524

Prignano L, Morer I, Fulminante F, Lozano (2019) Modelling terrestrial route networks to understand inter-polity interactions (southern Etruria, 950-500 BC). Journal of Archaeological Science 105: 46-58. https://doi.org/10.1016/j.jas.2019.02.007

Puyo JY, Castañón Álvarez JC, García Álvarez J (2016) Cartographier et décrire la péninsule Ibérique: l'héritage militaire français (1808-1823). Ann Geogr 707:74-102

Quad M, Eichovio C (1604) Deliciae Hispaniae et Index Viatorius, Indicans Itinera, Ab Vrbe Toleto, Ad Omnes in Hispani Civitates et Oppida. Ursel: Cornelij Sutorij. https://books.google.es/books/about /Deliciae_Hispaniae_et_index_viatorius_in.html?id=YB5YAAAAcAAJ\&redir_esc=y. Accessed 19 Sept 2020

Quiroga (1811) Mapa de España Dividido En Prefecturas y Divisiones Militares. https://gallica.bnf.fr/ ark:/12148/btv1b53102989x/f1.item.zoom. Accessed 18 Oct 2019

Reggiani A, Nijkamp P (2009) Complexity and spatial networks: in search of simplicity. Advances in spatial science. Springer, Berlin

Rietveld P, van Nierop J (1995) Urban growth and the development of transport networks: the case of the dutch railways in the nineteenth century. Flux 19:31-43. https://doi.org/10.3406/flux.1995.1016

Reguera Rodríguez AT (1999) Los "Apuntamientos" del Padre Martin Sarmiento sobre la construcción de la Red Radial de Caminos Reales en España. Llull 22:475-506

Riley S, Degloria SD, Elliot R (1999) A terrain ruggedness index that quantifies topographic heterogeneity. Int J Sci 5(1-4):23-27

Ringrose DR (1972) Los transportes y el estancamiento económico en España (1750-1850). Tecnos, Madrid

Rodríguez González C (1983) Los viajes «a La Ligera»: un medio tradicionalmente rápido de transporte, desbancado por el ferrocarril. Investigaciones Históricas: Época Moderna y Contemporánea 4:159-184

Rosés JR, Martínez-Galarraga J, Tirado-Fabregat DA (2010) The upswing of regional income inequality in Spain (1860-1930). Explor Econ Hist 47(2):244-257. https://doi.org/10.1016/j.eeh.2010.01.002

Rowlands R (1576) The Post for Diuers Partes of the World to Trauaile from One Notable Citie unto an Other, with a Description of the Antiquitie of Diuers Famous Cities in Europe. Thomas East, London

Ruiz R, Rodríguez FJ, Coronado JM (2015) Exploring landscapes through modern roads: historic transport corridors in Spain. Landscapes 16(1):44-62. https://doi.org/10.1179/1466203515Z.00000 000040

Sanson N (1652) Royaume de Navarre. Divisée En Six Merindades. Pierre Mariette. http://www.navar ra.es/home_es/Temas/Turismo+ocio+y+cultura/Archivos/Programas/Archivo+Abierto/Docum entos/Royaume-de-Navarre-divise-en-six-merindades_Ch*AWI4SqvqOBA2NVPINHw. Accessed 18 Oct 2019 
Sanson N (1691) Les Monts Pyrenees, Ou Sont Remarqués Les Passages de France En Espagne. Chez H. laillot, joignant les grands Augustins, aux deux Globes. https://www.ign.es/web/catalogo-carto teca/resources/html/002879.html. Accessed 18 Oct 2019

Sanson N (1700) L’Espagne Divisée En Tous Ses Royaumes et Principautés. Jaillot, Paris

Sanson N, Tavernier M (1641) Carte Generale d'Espagne et de Tous Les Royaumes. http://gallica.bnf.fr/ ark:/12148/btv1b530780936. Accessed 18 Oct 2019

Sarmiento M (1757) Apuntamientos Para Un Discurso Sobre La Necesidad Que Hay En España de Unos Buenos Caminos Reales, y de Su Pública Utilidad. Edited by Antonio Valladares de Sotomayor and Blas Román. http://biblioteca.galiciana.gal/es/consulta/registro.cmd?id=2870. Accessed 18 Oct 2019

Schuler JE, Fauser A, Seifert T (1965) Der Älteste Reiseatlas Der Welt [Das Itinerarium Orbis Christiani, 1579-1580]. Schuler Verlagsgesellschaf, Stuttgart

Scheidel W (2014) The shape of the Roman world: modelling imperial connectivity. Journal of Roman Archaeology 27:7-32. https://doi.org/10.1017/S1047759414001147

Schweitzer F, Fagiolo G, Sornette D, Vega-Redondo F, Vespignani A, White DR (2009) Economic networks: the new challenges. Science 325(5939):422-426. https://doi.org/10.1126/science.1173644

Senex J (1708) A correct map of Spain and Portugal. John Bowles, Cornhill http://www2.ign.es/Mapas AbsysJPG/1062_12-D-43.jpg. Accessed 18 Oct 2019

Serra A (2003) "Monopolio naturale" di autori postali nella produzione di guide italiane d'Europa, fonti storico-postali fra Cinque e Ottocento. Archivio per la storia postale 14-15:19-80. http://risor se.issp.po.it/rivista/asp14-Serra.pdf. Accessed 18 Oct 2019

Shaw MC (2009) El Siglo de Hacer Caminos- Spanish Road Reforms during the Eighteenth Century. A Survey and Assessment. Dieciocho 32(2):413-435

Smith A (1776) An inquiry into the nature and causes of the the wealth of nations. W, Straham and T. Cadell, London

Stella CD, L'Herba GD (1564) Poste per Diverse Parti Del Mondo. Et Il Viaggio Di S. Giacomo Di Galitia, Tutte Le Fiere Principali Del Mondo. La Narratione Di Roma, e Delle Sette Chiese Brevemente Ridotta. Venice: Domenico Farri. https://books.google.es/books?id=NDISAAAAcAAJ\&print $\mathrm{sec}=$ frontcover\&hl=es\&source $=\mathrm{gbs} \_g$ e_summary_r\&cad $=0 \# \mathrm{v}=$ onepage $\& \mathrm{q} \& \mathrm{f}=\mathrm{false} . \quad$ Accessed 18 Oct 2019

Strano E, Adamatzky A, Jones J (2012) Vie Physarale: Roman Roads with Slime Mould. Bioeval World Transp Netw. World Scientific. https://doi.org/10.1142/9789814407045_0010

Thuillier, Barrière (1838) Nouvelle Carte Routiere d'Espagne et de Portugal. Paris: chez Mme. Vve. Turgis, Rue S. Jacques $\mathrm{N}^{\circ} 16$ et à Toulouse Rue S. Rome, $\mathrm{n}^{\circ} 36$. http://bdh-rd.bne.es/viewe r.vm?id=0000031140. Accessed 19 Sept 2020

Tofiño de San Miguel V, López de Vargas y Machuca T, Semen (1823) "Nouvelle Carte Politique et Itinéraire de l'Espagne et Du Portugal : Avec La Nouvelle Division Des Cartes En 51 Provinces." Hyacinthe Langlois, Paris. http://gallica.bnf.fr/ark:/12148/btv1b53078898g. Accessed 18 Oct 2019

Tortella G (1973) Los Orígenes del Capitalismo en España. Banca, Industria y Ferrocarriles En el siglo XIX. Tecnos, Madrid

Tsompanas M-AI, Sirakoulis GCh, Adamatzky A (2016) Cellular Automata Models Simulating Mould Computing. In: Adamatzky A. (eds) Advances in physarum machines. emergence, complexity and computation, vol 21. Springer, Cham. https://doi.org/10.1007/978-3-319-26662-6

Uriol Salcedo JI (1977) Apuntes para una historia del transporte en España. Los viajes por la posta en el siglo XVIII y en los primeros años del siglo XIX. Revista de Obras Públicas 124(3151):837-856

Uriol Salcedo JI (1985a) Apuntes para una historia del transporte en España. Los últimos años de los transportes hipomóviles. Revista de Obras Públicas 132(3232):25-32

Uriol Salcedo JI (1985b) Las calzadas romanas y los caminos del siglo XVI. Revista de Obras Públicas, Madrid, pp 553-563

Uriol Salcedo JI (2001) Historia de los caminos de España Vol. I Hasta el siglo XIX. 2nd ed. Colegio de Ingenieros de Caminos, Canales y Puertos, Madrid

Valk G (1704) Regna Hispaniarum Atque Portugalliae. Amsterdam. https://www.ign.es/web/catalogocartoteca/resources/html/002980.html. Accessed 18 Oct 2019

van der Aa (1707) Novissima et Accuratissima Tabula Regnorum Hispaniae et Portugalliae. Leiden. http://bdh-rd.bne.es/viewer.vm?id=0000019673. Accessed 18 Oct 2019

van der Aa B, Jordan C (1700) Zeer Gedenkwaardige En Naaukeurige Historische Reis-Beschrijvinge, Door Vrankrijk, Spangie, Italien, Duitsland, Engeland, Holland En Moscovien. Boudewyn van der Aa. https://lib.ugent.be/catalog/rug01:001738215. Accessed 19 Sept 2020 
Vanoutrive T, De Block G, Van Damme I (2018) Nature's order? Questioning causality in the modelling of transport networks. Geoforum 97(December):324-334. https://doi.org/10.1016/j.geofo rum.2018.09.026

Villuga PJ (1546) El Reportorio de Todos Los Caminos de España: Hasta Agora Nunca Visto En El Q1 Allará Qlquier Viaje q Quiera Andar Muy Pvechoso Pa Todos Los Caminantes. Medina del Campo: Pedro de Castro a costa de J. de Espinosa. https://archive.org/details/reportoriodetodo00vi 11. Accessed 18 Oct 2019

Visscher N (1704) Regnorum Castellae Veteris, Legionis et Gallaeciae Principatuum q Biscaiae et Asturiarum Accuratissima Descriptio. http://purl.pt/3749. Accessed 19 Sept 2019

Visscher N (1705) Regnorum Castellae Novae Andalusiae Granadae Valentiae et Murciae Accurata Tabula. http://cartotecadigital.icc.cat/cdm/singleitem/collection/espanya/id/1945/rec/2. Accessed 19 Sept 2019

Voigtlaender N, Voth H-J (2019) Highway to Hitler. Working Paper 20150. https://www.nber.org/papers/ w20150.pdf. Accessed 18 Oct 2019

Vromen JJ (1995) Economic evolution: an inquiry into the foundations of the new institutional economics. Routledge, Cambridge

Ward B (1762) Proyecto Económico, En Que Se Proponen Varias Providencias, Dirigidas à Promover Los Intereses de España, Con Los Medios y Fondos de Necesarios Para Su Plantificación. Segunda. Madrid: Joachin Ibarra. https://books.google.es/books?id=S4wEmgG-ys4C. Accessed 18 Oct 2019

Wasserman S, Katherine F (1994) Social network analysis: methods and applications. Cambridge Univeristy Press, Cambridge

Watts DJ (2003) Six degrees: the science of a connected age. Vintage, London

Weber J (2012) The Evolving Interstate Highway System and the Changing Geography of the United States. J Transp Geogr 25:70-86. https://doi.org/10.1016/j.jtrangeo.2012.07.012

Wehrheim L (2019) Economic history goes digital: topic modeling the journal of economic history. Cliometrica 13:83-125. https://doi.org/10.1007/s11698-018-0171-7

Wertheim H (1935) Der Erste Europäische Straßenatlas. Imago Mundi 1(1):41-43. https://doi. org/10.1080/03085693508591810

Publisher's Note Springer Nature remains neutral with regard to jurisdictional claims in published maps and institutional affiliations.

\section{Affiliations}

\section{Federico Pablo-Martí ${ }^{1,2}$ - Ángel Alañón-Pardo ${ }^{3}$ - Angel Sánchez ${ }^{4,5,6}$}

1 Facultad de CC. Económicas, Empresariales y Turismo, Plaza de la Victoria, 3, 28802 Alcalá de Henares, Madrid, Spain

2 Grupo de Investigación Sistemas Complejos en Ciencias Sociales (SCCS), Departamento de Economía, Universidad de Alcalá, 28801 Alcalá de Henares, Madrid, Spain

3 Instituto Complutense de Estudios Internacionales, and Departamento de Economía Aplicada, Estructura e Historia, Universidad Complutense de Madrid, 28223 Pozuelo de Alarcón, Madrid, Spain

4 Unidad Mixta Interdisciplinar de Comportamiento y Complejidad Social (UMICCS), UC3M-UV-UZ, and Grupo Interdisciplinar de Sistemas Complejos (GISC), Departamento de Matemáticas, Universidad Carlos III de Madrid, 28911 Leganés, Madrid, Spain

5 Instituto de Biocomputación y Física de Sistemas Complejos (BIFI), Universidad de Zaragoza, 50018 Zaragoza, Spain

6 UC3M-Santander Big Data Institute (IBiDat), Universidad Carlos III de Madrid, 28903 Getafe, Madrid, Spain 